\author{
Universidade de São Paulo \\ Faculdade de Odontologia de Bauru
}

\title{
EFEITO DO VEGF NA ANGIOGÊNESE PULPAR E NA APOPTOSE
}

\section{Silvana Beltrami Gonçalves}

Tese apresentada à Faculdade de Odontologia de Bauru da Universidade de São Paulo, como parte dos requisitos para obtenção do título de Doutor em Odontologia, na área de Endodontia.

Bauru 


\author{
Universidade de São Paulo \\ Faculdade de Odontologia de Bauru
}

\title{
EFEITO DO VEGF NA ANGIOGÊNESE PULPAR E NA
}

\section{APOPTOSE}

\section{Silvana Beltrami Gonçalves}

Tese apresentada à Faculdade de Odontologia de Bauru da Universidade de São Paulo, como parte dos requisitos para obtenção do título de Doutor em Odontologia, na área de Endodontia.

Orientador: Prof. Dr. Clovis Monteiro Bramante

Bauru

2006 


\section{Gonçalves, Silvana Beltrami}

G586e Efeito do VEGF na angiogênese pulpar e na apoptose / Silvana Beltrami Gonçalves.-- Bauru, 2006.

xxiii, 153 p. : il. ; $30 \mathrm{~cm}$.

Tese (Doutorado) -- Faculdade de Odontologia de Bauru. Universidade de São Paulo.

Orientador: Prof. Dr. Clovis Monteiro Bramante

Comitê de Ética da Escola de Odontologia, Universidade de Michigan.

Projeto UCUCA 8754

Autorizo, exclusivamente para fins acadêmicos e científicos, a reprodução total ou parcial desta dissertação/tese, por processos fotocopiadores e outros meios eletrônicos.

\section{Assinatura:}

Data: 


\section{DEDICATÓRIA}

A Deus, nosso pai, eu agradeço pela força, serenidade, persistência e saúde, condições estas que me possibilitaram a realização deste trabalho.

A Santa Paulina,

Fundadora da Congregação das Irmãzinhas da Imaculada Conceição, Canonizada pelo Papa João Paulo II no dia 19 de maio de 2002 - RomaVaticano. Fonte inspiradora e exemplo de vida, sempre presente em meus pensamentos e orações. Suas mensagens proporcionaram-me palavras de ânimo, coragem e perseverança em todos os momentos de minha vida durante o período de desenvolvimento deste trabalho.

\section{" $\mathcal{N}$ unca, jamais desanimeis, embora venham ventos contráríos!' \\ Santa Paulina}

\section{À minha família}

\section{Pai, Mãe, meu irmão e cunhada}

Mais uma vez vocês depositaram confiança em mim, acreditaram nos meus sonhos e me ajudaram a realizá-los. Muito obrigada por todo o apoio dispendido e amor oferecido durante a realização deste trabalho.

À minha Vó Helena, que sempre me acompanha por meio de suas orações.

À minha Vó Dolfina e Vô Sílvio que, mesmo não se encontrando mais entre nós, deixaram conhecimentos a serem sempre lembrados e seguidos por toda a minha caminhada.

\section{A duas pessoas muito especiais!}

Tio Waltrick (in memoriam), obrigada pelo carinho e por sempre me ter tratado como uma filha! Há pessoas que, mesmo não estando mais entre nós, deixam muita saudade! O senhor, com certeza, é uma delas!

Cristhian, obrigada pelo apoio, incentivo, força, amizade, compreensão e principalmente pelo seu amor. São anos de amizade, admiração e respeito transformados em um sentimento muito lindo entre nós. 


\section{MEUS ETERNOS AGRADECIMENTOS}

\section{Prof. Dr. Jacqües Eduardo $\mathcal{N}$ ör}

Obrigada pela oportunidade da realização deste trabalho em seu laboratório de pesquisa na Universidade de Michigan, na cidade de Ann Arbor, experiência esta ímpar em minha vida! Muito obrigada por tudo

que fez por mim, pela sua forma de orientação, fazendo- me trilhar o caminho por mim mesma; pela sua paciência, sabedoria compartilhada, incentivo, amizade e principalmente pela confiança depositada em mim. Sua simplicidade e enorme sabedoria foram e sempre serão qualidades valiosas a serem seguidas no desenvolvimento de um docente. Serei grata para sempre, meu mestre e amigo. 


\section{OBRIGADA POR TUDO}

\section{Prof. Dr. Clovis Monteiro Bramante}

Não tenho palavras para expressar a eterna gratidão ao senhor. O seu incentivo à realização deste trabalho na Universidade de Michigan foi fundamental para a minha perseverança em investir neste sonho. Agradeço pelos conhecimentos científicos compartilhados, pelo apoio prestado sempre no momento certo, e principalmente pela confiança em mim depositada! Sua orientação desde a minha especialização serviu como estímulo ao meu interesse pela docência. Muito obrigada por tudo! 


\section{EM ESPECIAL AGRADEÇO}

Ao Prof. Dr. Roberto Brandão, pela disponibilidade em ajudar sempre quando questionado, pela atenção, amizade e por todos os conhecimentos compartilhados.

Ao Prof. Dr. Ivaldo e família (Tia Carminha, Renata, Fernanda e Guilherme), pela amizade, carinho e atenção dispendidos durante a realização desta pesquisa. Obrigada pela hospitalidade oferecida durante os meses finais de redação desta pesquisa.

Ao Prof. Dr. Carlos (Cebola), pela amizade, pelos conhecimentos compartilhados e por toda a atenção e ajuda dispendida.

Ao Prof. Dr. Norberti Bernardineli, pelo incentivo e confiança para a realização do estágio no PDEE.

À Faculdade de Odontologia de Bauru - FOB/USP, pelo incentivo prestado à realização do PDEE através do apoio da Prof. Dra. Maria Fidela de Lima Navarro e do Prof. Dr. Luiz Fernando Pegoraro, atual diretor desta instituição.

A CAPES, pelo incentivo dado à pesquisa através da bolsa para PDEE.

Aos colegas de pós-graduação: Viviane, Everdan, Renato, Fábio, Ulisses, Fernanda, Giovana, Graziela, Rogério, pelos conhecimentos compartilhados e amizade dispendida durante todo o período do doutorado.

Aos funcionários do departamento de Endodontia: Suely Regina Bettio, Edimauro de Andrade, Neide Leandro, Patrícia Fernanda Vital Lopes e Cleide Vital, pela amizade e ajuda sempre prestada durante o período do doutorado. 
Aos funcionários da Biblioteca: Amauri, César, Rita e Vera pela disposição constante em ajudar.

Aos funcionários do xerox: Salvador e Paula, pela amizade e pela impressão deste trabalho.

À Valéria, pela correção das referências bibliográficas.

Ao Prof. Dr. José Roberto Pereira Lauris, pelos esclarecimentos referentes aos dados estatísticos.

A Profa. Eloísa, pela revisão do vernáculo.

Ao meu Tio querido Eduardo Peixoto, agradeço pela sabedoria compartilhada!

À Tia Rosilda, Mariângela, Rosane, Ricardo, Gabriela, Rafael e Jefferson, pela amizade e carinho sempre presente.

Ao meu grande amigo Ulisses e Tia Carmem, que sempre me incentivaram para a realização do estágio de doutorado no exterior, e que me acolheram em Curitiba para a realização da prova do TOEFL e sempre me apoiaram em todos os momentos.

À minha irmã de coração Luciana Marques Mesko, que me acompanha mesmo que à distância em todos os momentos da minha vida. Agradeço pelos conselhos dados, amizade, carinho e amor.

À minha querida amiga Fernanda Gomes de Moraes, pelos e-mails de apoio e carinho enviados durante o período em que estava em Ann Arbor. Sua amizade é muito importante para mim!

Às minhas amigas Jaqueline, Giovana e Karine, pela amizade mantida mesmo que à distância. 
À Viviane Brosco e família (Tio Wantuir e Tia Wadet), pelo carinho sempre presente durante a realização do curso de doutorado.

À amigona Rosário, pelo conhecimento compartilhado durante o período do doutorado.

Aos amigos Carlos Neanes Santos e Marcio Chiminazzo, pelo incentivo, apoio e ajuda prestada nos momentos que antecederam a viagem para Ann Arbor.

À Letícia e Evandro, pela amizade e apoio prestado durante o período da redação final desta pesquisa.

Aos colegas Alessandra, Eduardo, Ana e Mabel, estudantes de Mestrado, Doutorado e Pós- Doutorado na Universidade de Michigan durante o período do meu estágio. Obrigada pelo conhecimento compartilhado e principalmente pela amizade.

À minha querida amiga Letícia, obrigada pela amizade e por todos os conhecimentos compartilhados, bem como por toda a ajuda prestada em diversos momentos durante a sua estada em Ann Arbor.

À minha querida amiga Carolina Nör, obrigada pelas conversas no Starbucks entre um café e outro. O período em que estávamos juntas em Ann Arbor sempre estará guardado em minha memória.

Aos amigos Rodrigo Neiva e Kathleen Neiva, pelo apoio e amizade em todos os momentos da minha estada em Ann Arbor. 
A todos amigos residentes na cidade de Ann Arbor: Halimah e James, Yasmine e André, Fernanda Lima e Brad, Fernanda Facchin e Adolfo, Solange, Gustavo, Luciana e Rodrigo, Sheila e Marcus, Tizziane, Cleber Teixeira, Saulo, Tamara e Branco, Shaun e Marcelo, obrigada pelos momentos que, juntos, vivenciamos e pela ajuda nos diversos momentos em que precisei.

Com carinho a Sheila, Luciana e ao amigo Saulo, pelo apoio, incentivo, força e amizade prestada durante o período de desenvolvimento do estágio em Ann Arbor. Vocês, com certeza, estarão sempre em minhas memórias e em meu coração! 


\section{Acknowledgements}

I would like to thank Professor Dr. Graham Rex Holland, for giving me the opportunity to work with him. And thank him for his guidance, together with Dr. Nör, during this project. Thanks for the friendship and encouragement from the beginning to the end

Professor Dr. Anthony J Smith (University of Birmingham, School of Dentistry), for his guidance during this project, especially in the development of the tooth slices culture, used in this project.

Professor Tatiana Botero, for her friendship and encouragement. Thanks for giving me the opportunity to learn all Lab procedures. Thanks for sharing all your knowledge about RT-PCR and cell culture with me. Thanks for everything!

Nör's lab: Zhihong Dong, Zhaocheng, Elisabeta, Kathleen, Tomoatsu, Tatiana, Ryan, Lindsye, Ester and Pomp, with whom it was a great pleasure to work with. Thanks for everything! Everyone was so important in all phases during the development of this project. I would especially like to mention my friend Ben Zeitlin, Ph.D. and my dear friend Kristy. Thanks so much for giving me the opportunity to learn so many different things and thanks for helping me with the mice, during the in vivo study. I will never forget them! Thanks for the friendship! Zhihong, thanks for the help with the immunohistochemistry! Zhaocheng, thanks you for the help with RT-PCR analyses.

Chris Strayhorn and John Westman, for the hard work with my slides! Thanks for my H\&E staining. Chris Strayhorn, for his time and instructions for using the microscope and computer, in order to photograph the immunohistochemistry slides. 
In special, Cindy, for the friendship, encouragement, hospitality and support in many different moments, during my time in Ann Arbor. I will never forget what she did for me! Thanks so much!

Tao, for his friendship, and help with the spectrophotometer.

Ruth Eberhart and Susan Douglas, thanks so much for the friendship, and help with different things. It was a great pleasure to meet both of you. Thanks so much for everything! I miss you!

Jim, thanks for helping me with the computer. Thanks so much for everything! And also, thanks for the friendship.

Division of Oral surgery: the staff, students and secretaries. Thank you so much for the attention and help with the schedule of the best day to get the teeth for my project. I would like to mention my friend Tracy, who was always so kind to me!

Stephen J. Durkee, thank you for the lectures, guidance on the use and care of animals, which helped me so much during my experiment.

Professor Dr. Tilly Peters, thanks so much for her friendship. 


\section{SUMÁRIO}

LISTA DE ABREVIATURAS E SÍMBOLOS...................................................

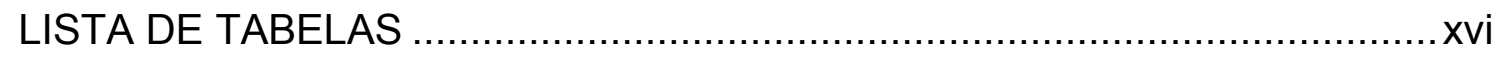

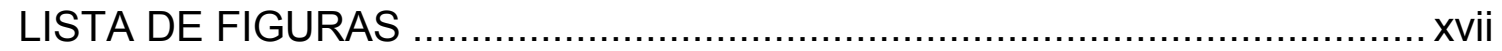

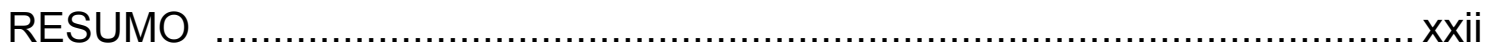

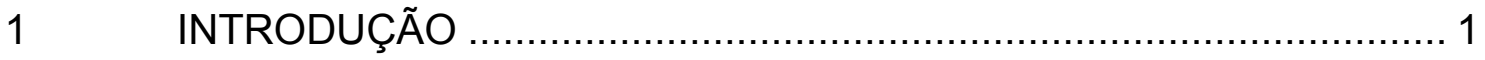

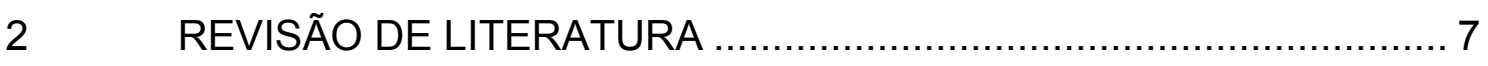



2.1.1 Terapia Angiogênica....................................................................... 13

2.2 FATOR DE CRESCIMENTO VASCULAR ENDOTELIAL -VEGF...... 14

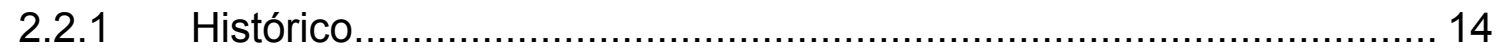

2.2.1.1 Fator de permeabilidade vascular (VPF) .................................... 14

2.2.1.2 Fator de crescimento vascular endotelial (VEGF) ........................... 15

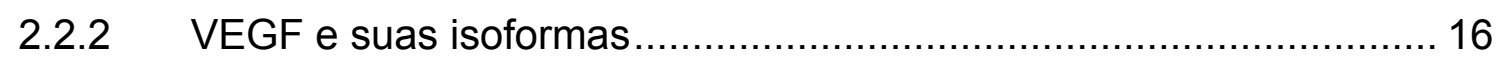

2.2.3 VEGF e seus receptores ........................................................ 18

2.2.4. Ações e propriedades do VEGF .................................................. 20

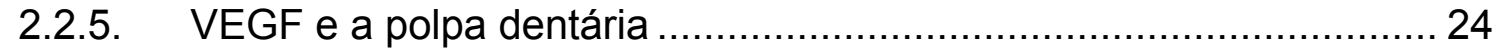

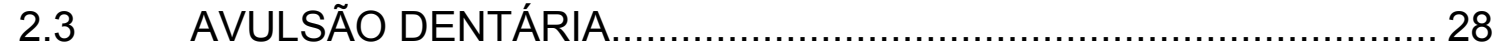

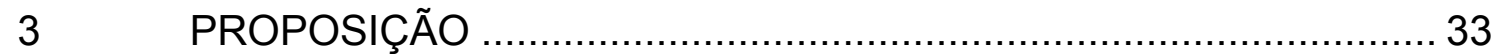

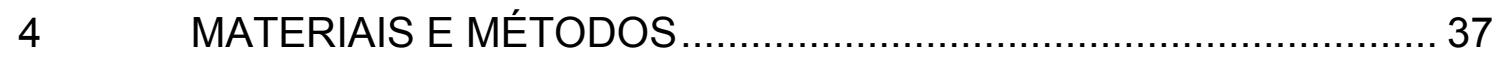

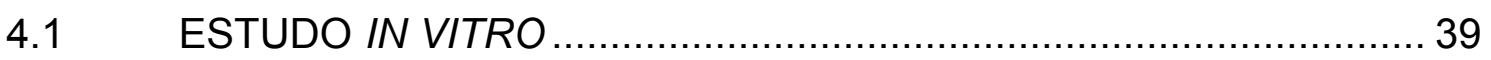

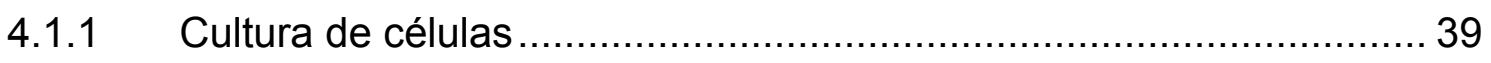

4.1.2 Transcrição reversa - reação em cadeia de polimerase (RT- PCR

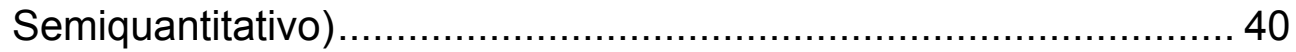

4.1.3 Coleta, preparação das fatias de dente e cultura ............................. 41

4.1.4 Processamento Laboratorial..................................................... 47

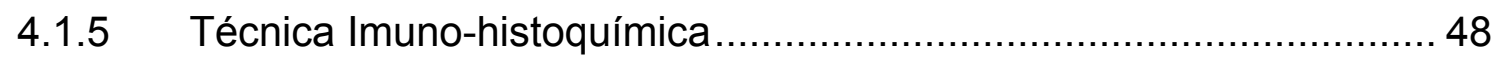

4.1.6 Teste do Tunel ( Tunel Assay - In situ cell death detection kit- AP)...48

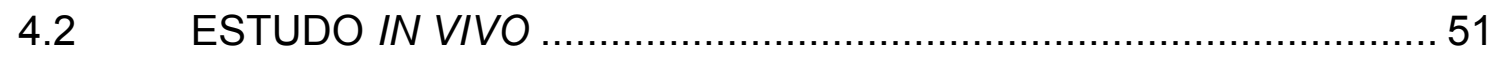

4.2.1 Intervenção cirúrgica .............................................................. 52 


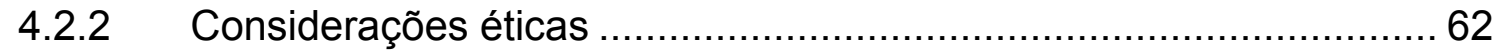

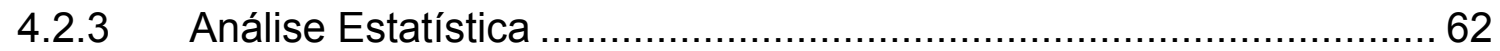

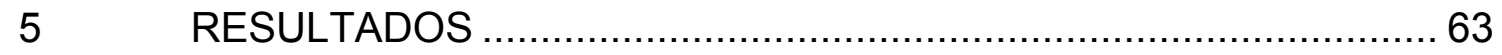

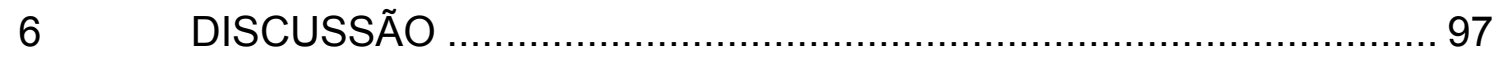

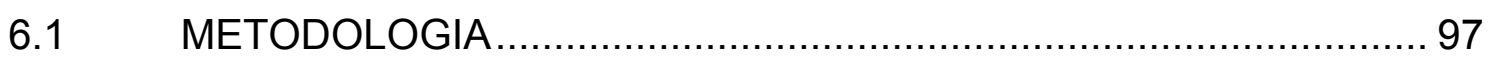

6.1.1 Estudo in vitro - cultura das fatias dentárias ........................... 97

6.1.2 Estudo in vitro - cultura celular e RT-PCR ................................ 101

6.1.3 Estudo in vitro - Imuno-histoquímica...................................... 102

6.1.4 Estudo in vitro - Teste do Tunel (In situ cell death detection kit, AP)

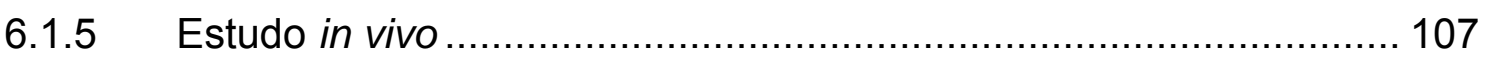

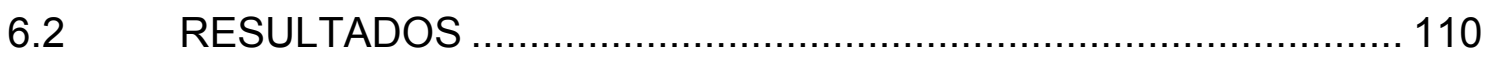

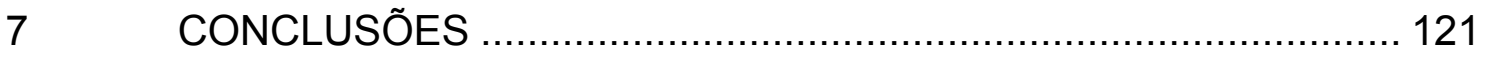

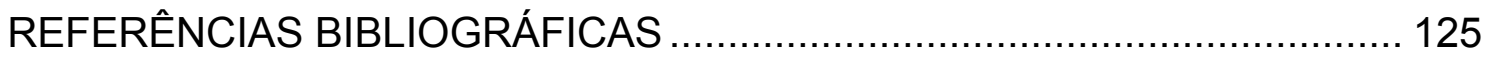

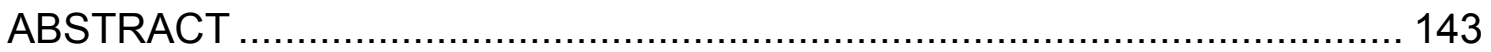

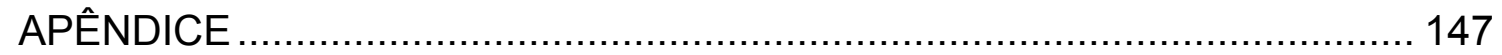




\section{LISTA DE ABREVIATURAS E SÍMBOLOS}

$\%$

$+/-$

$\mu \mathrm{m}$

$\mu \mathrm{g} / \mathrm{ml}$

${ }^{\circ} \mathrm{C}$

AP-1

bFGF

$\mathrm{Bp}$

cDNA

dp

FC

Flk-1

Flt-1

Flt-4

FVIII RAg

9

G+

G-

GAPDH

$\mathrm{h}$

HDMECs

HE

IL

$\mathrm{kDa}$

KDR

LPS

LTA

$\mathrm{M}$
Expressa um valor em percentual

Média

Micrometros

Microgramas por mililitro

Graus centígrados (Celsius)

Activator protein-1

Basic fibroblast growth factor

Pares de base

DNA complementar

Desvio padrão

Fator de crescimento

Fetal liver kinase-1

Fms-like tyrosine- kinase-1

Fms-like tyrosine-kinase-4

Factor VIII- related antigen

Gramas

Gram positivas

Gram negativas

Glyceraldehyde 3- phosphate dehydrogenase

Gliceraldeído adenosina fosfato desidrogenase

Horas

Células endoteliais da microvasculatura da derme humana

Hematoxilina e eosina

Interleucina

Kilo dalton

Kinase domain region

Lipolissacarídeos

Ácido lipoteicóico

Molar 
MDPC-23

MEC

Min

mRNA

OD-21

$\mathrm{pg} / \mathrm{ml}$

P.A.

PB

PCR

PDGF

PIGF

RTK

RT-PCR

T.A.

TGF alfa

TGF beta

TLR2

TNF alfa

UCUCA

ULAM

VPF

VEGF

VEGFR-1

VEGFR-2

VEGFR-3

VPF
Células tipo odontoblasto

Matriz extracelular

Minuto

Ácido ribonucléico mensageiro

Células pulpares indiferenciadas

Picogramas por mililitro

Pró-Análise

Phosphate buffereds

Polymerase Chain Reaction

Plateled derived growth factor

Placenta growth factor

Tyrosine-kinase receptor

"Reverse transcriptase polymerase chain reaction"

Temperatura ambiente

Transforming growth factor- alfa

Transforming growth factor- beta

Toll like receptor-2

Tumor necrosis factor- alfa

University Committee on Use and Care of Animals

Unit for Laboratory Animal Medicine

"Vascular permeability factor" (fator de permeabilidade vascular)

"Vascular endothelial growth factor" ( fator de crescimento vascular endotelial)

Vascular endothelial growth factor receptor-1 (receptor 1 do fator de crescimento vascular endotelial)

Vascular endothelial growth factor receptor-2 (receptor 2 do fator de crescimento vascular endotelial)

Vascular endothelial growth factor receptor-3 (receptor 3 do fator de crescimento vascular endotelial)

"Vascular permeability factor" (fator de permeabilidade vascular) 


\section{LISTA DE TABELAS}

\section{Revisão de Literatura}

Tabela A Especificidade dos receptores ao ligante VEGF e efeitos biológicos.

Materiais e Métodos

Tabela B Distribuição dos Grupos 45

\section{Resultados}

Tabela 1 -Dados obtidos com o estudo in vitro pela técnica de imunohistoquímica (número de vasos sangüíneos) e teste de Tunel (número de células apoptóticas) encontrados no grupo controle (sem VEGF) e no grupo experimental (50ng/ml VEGF). 


\section{LISTA DE FIGURAS}

Figura 1 Estabilização do dente e adaptação na máquina de corte (Isomet). . 43

Figura 2 Preparação das fatias dentárias ............................................... 45

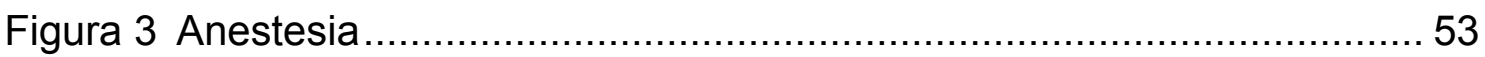

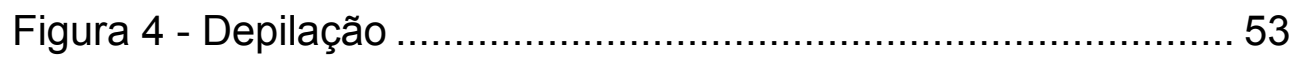

Figura 5 (A) Incisão, (B) divulsão e (C) implantação das fatias dentárias. ..... 55

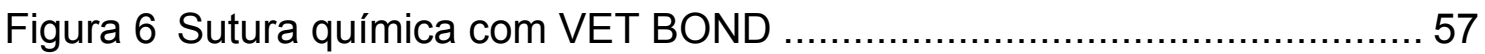

Figura 7 Remoção das fatias dentárias após 7 dias da implantação...............5 57

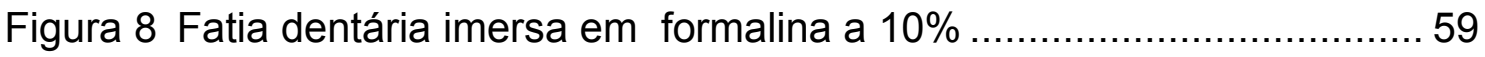

Figura 9 Representação gráfica das médias dos números de vasos sangüíneos observados nos cortes pela marcação de imuno-histoquímica em função do usoou não do VEGF.

Figura 10 Representação gráfica das médias dos números de células apoptóticas observadas nos cortes pela marcação com o teste de TUNEL em função do uso ou não do VEGF.

Figura 11 Tecido pulpar e camada odontoblástica com aspecto de normalidade nos grupos controle (A e B) e VEGF 50ng/ml (C e D), magnificação de 200x, HE).

Figura 12 Tecido pulpar e camada odontoblástica com aspecto de normalidade nos grupos controle (A e B) e VEGF 50ng/ml (C e D), magnificação de 400x, (HE).

Figura 13 Imunomarcação para células endoteliais e vasos sangüíneos (Fator VIII, vermelha (AEC). Controle (A) e VEGF 50ng/ml (B), magnificação de 200x. $D=$ dentina; $P D=$ pré-dentina; camada de odontoblasto * 
Figura 14 Imunomarcação para células endoteliais e vasos sangüíneos (Fator VIII - vermelha -AEC). Controle (A) e VEGF 50ng/ml (B), magnificação de 400x.

Figura 15 Marcação para células apoptóticas (setas) pelo teste do Tunel (BCIP/NBT - azul escuro) para os grupos controle (A) e VEGF 50ng/ml (B), magnificação de 200x.

Figura 16 Marcação para células apoptóticas (setas) pelo teste do Tunel (BCIP/NBT azul escuro) para os grupos controle (A) e VEGF 50ng/ml (B), magnificação de 400x.

Figura 17 Controle negativo para o teste de Tunel (BCIP/NBT - azul escuro magnificação de 200x.

Figura $18 \mathrm{Gel}$ de agarose corado com brometo de etídeo para a detecção, por RT-PCR, da expressão do RNAm para VEGFR-2 (1, 2, 3 e 4) em células endoteliais- HDMEC (1), OD-21 (2), MDPC-23 (3) e macrófagos (4). Os cDNAs foram amplificados por PCR com primers específicos para VEGFR-2 (928 pb) e para GAPDH (683 pb), controle interno da reação. Controle positivo $\operatorname{HDMEC}(1,5)$; Coluna 1, RNAm para VEGFR-2 detectado nas células (HDMECs); Coluna 2,3 e 4 PCR de RNA total das células utilizando primers específicos para VEGFR-2; Coluna 5, 67 e 8 RNAm para GAPDH detectado nas células (HDMEC (5), OD-21 (6), MDPC-23 (7) e macrófagos (8). M, marcador de peso molecular de $1 \mathrm{~kb}$. 85

Figura 19 Fatia dentária apresentando tecido pulpar vascularizado após 7 dias da implantação.

Figura 20 Tecido pulpar com aspecto de normalidade, apresentando um significante número de células e vasos sangüíneos ( HE magnificação de 200x (A) e 400x (B).

Figura 21 Imunomarcação para vasos sangúíneos e células endoteliais (Fator VIII -vermelho AEC), confirmando a viabilidade do tecido pulpar após os 7 dias de implantação. Magnificação de 200x. Camada de odontoblasto íntegra*. 
Figura 22 Células apoptóticas (setas) no tecido pulpar. Teste de Tunel. Magnificação de 200x (A) e 400x (B). 93

\section{Figura da Discussão}

Figura A Aspectos da camada odontoblástica, morfologia dos odontoblastos e aspectos de normalidade do tecido pulpar após o período de 7 dias em cultura com VEGF (A.1) e após a implantação das fatias dentárias no subcutâneo dos camundongos imunodeficientes (A.2). HE com 400x de magnificação. 113

\section{Figura do Apêndice}

Figura A Tecido pulpar e camada odontoblástica com aspectos de normalidade, apresentando significante número de células e vasos sangüíneos. (HE 10x (A.1); e 400X (A.2; A.3) 



\section{RESUMO}

\section{EFEITO DO VEGF NA ANGIOGÊNESE PULPAR E NA APOPTOSE}

O fator de crescimento vascular endotelial (VEGF) desempenha um papel importante na angiogênese, induzindo a proliferação da célula endotelial, migração e sobrevivência. Com o intuito de promover a formação de novos vasos, e obter uma melhora na circulação colateral, VEGF tem sido utilizado para o tratamento de áreas de isquemia cardíaca, na doença cardiovascular. A manutenção da vitalidade pulpar com VEGF pode melhorar o prognóstico dos dentes que sofreram avulsão, prevenindo a perda precoce do dente. $O$ propósito deste estudo foi desenvolver um modelo para se estudar o processo de revascularização da polpa dentária e avaliar o efeito do VEGF165 na angiogênese da polpa humana e na apoptose. Fatias de dente humano foram mantidas in vitro (cultura) com e sem VEGF $(50 \mathrm{ng} / \mathrm{ml})$ durante 7 dias. Coloração de imuno-histoquímica para o Fator de Von Willebrand (Fator VIII) foi utilizada para quantificar o número de vasos sangüíneos no tecido pulpar. $O$ número de vasos sangüíneos foi significantemente mais alto no grupo do VEGF (média -67.87) comparado ao grupo controle (média- 46.25, $p \leq 0.05$ ). O teste do Tunel foi usado para determinar o número de células apoptóticas nos grupos com e sem VEGF. Análises da expressão de VEGFR-2 por RT-PCR foram realizadas nas células endoteliais da microvasculatura da derme humana (HDMECs), células pulpares indiferenciadas (OD-21), células tipo odontoblasto de camundongo (MDPC-23) e macrófagos. A expressão de VEGFR-2 foi detectada nas HDMECs, mas não nas outras 3 linhas celulares. Quatro fatias de dente humano por camundongo imunodeprimido foram implantadas na região dorsal, subcutaneamente, pelo período de 7 dias. A vitalidade pulpar foi determinada pelas análises microscópica e imuno-histoquímica. $O$ teste do Tunel foi usado para determinar o número de células apoptóticas. O modelo de angiogênese pulpar utilizando camundongos imunodeprimidos (SCID mouse model of pulp angiogenese) demonstrou ser um modelo viável para se estudar 
o processo de revascularização da polpa dentária humana. Levando-se em consideração os resultados obtidos neste estudo, sugere-se que o VEGF possa ter um efeito positivo na revascularização de dentes avulsionados. $E$ que o modelo de angiogênese pulpar desenvolvido nesta pesquisa possa ser útil para responder a inúmeras novas questões experimentais na área de Endodontia.

PALAVRAS-CHAVE: Angiogênese, Fator de crescimento vascular endotelial VEGF, VEGFR-2, Polpa dental avulsão. 
1 INTRODUÇÃO 



\section{INTRODUÇÃO}

Acidentes envolvendo os elementos dentários são comuns. A incidência das avulsões varia de 0,5 a $16 \%$ dos traumatismos dentoalveolares na dentição permanente. Os incisivos centrais superiores são os dentes mais freqüentemente avulsionados. Apesar de acontecerem em qualquer idade, as avulsões são mais comuns na dentição permanente, entre 8 e 12 anos de idade, período em que o ligamento periodontal ainda é uma estrutura flexível ao redor de dentes em irrupção e não oferece forte resistência às forças extrusivas encontrando-se, na maioria das vezes, dentes com risozênese incompleta (ANDREASEN \& ANDREASEN ${ }^{3}, 2001$ ).

Avulsões freqüentemente causam necrose pulpar. Enquanto a polpa necrótica por si só não provoca complicações, o tecido necrótico é bastante susceptível à contaminação bacteriana. Se a revascularização não ocorrer, ou se o tratamento endodôntico não for efetivamente instalado, o canal radicular será infectado (YANPISET; TROPE 144 , 2000). A combinação entre infecção bacteriana no canal radicular e lesão no cemento na superfície radicular resulta em reabsorção radicular externa, que pode levar à rápida perda do elemento dentário.

Por essas razões, várias terapêuticas vêm sendo pesquisadas para melhorar o prognóstico dos dentes avulsionados (SAE-LIM; METZER; TROPE ${ }^{112}$, 1998, CVEK et al. ${ }^{23,24}$, 1990; BUTTKE, TROPE ${ }^{14}, 2003$; LEVIN et al. ${ }^{73}$, 2001). A maioria dos pesquisadores continuam, porém, direcionando-se à procura de uma substância química que, aplicada ao dente, impediria o processo de reabsorção e anquilose alvéolo- dentária.

Em 1992, um produto que já vinha sendo utilizado no tratamento da doença periodontal, com o objetivo de promover a regeneração de partes do ligamento periodontal afetado, foi comercializado pela BIORA AB, Malmö, Sweden denominado de Emdogain (matriz de esmalte dentário), com o intuito de otimizar o processo de cicatrização do ligamento periodontal e evitar a anquilose (SCHJOOT, ANDREASEN ${ }^{115}$, 2005). A utilização do Emdogain (SCHJOOT, ANDREASEN ${ }^{115}$, 2005; ÇAGLAR et al. ${ }^{15}$, 2005) e do Alendronato 
(LEVIN et al. $^{73}$, LUTOSA-PEREIRA ${ }^{75}, 2005$; MORI $^{85}$, 2005), outro material amplamente investigado, faz-se presente em inúmeros trabalhos de traumatismo dentário, obtendo-se em alguns casos resultados positivos para ambos os materiais.

Ainda hoje, além da estocagem do dente avulsionado no leite (SIGALAS et al. ${ }^{122}, 2004$ ), substância mais amplamente utilizada, seguido do reimplante e contenção dentária, nada mais pode ser feito para melhorar as chances de revascularização. Entretanto, encontramos na literatura trabalhos que, indiretamente, objetivam o aumento da freqüência da revascularização pulpar utilizando outras substâncias, porém ainda não se tem nada padronizado como um novo protocolo de tratamento, sendo a maioria deles, estudos in vivo, desenvolvidos em tecido pulpar não humano.

Com o avanço do conhecimento científico revendo publicações na área de Medicina, encontramos proteínas expressadas pelo nosso organismo (ARTESE et al. ${ }^{5}, 2002$; BOTERO et al. ${ }^{13}$, 2003; ROBERTSCLARK, SMITH ${ }^{108}, 2000$; .TELLES et al. ${ }^{133}, 2003$ ) as quais, com o auxílio dos princípios de Biologia Molecular e Terapia Genética, estão sendo investigadas e aplicadas no tratamento de isquemias cardíacas em pacientes que não estão aptos para os tradicionais métodos de revascularização (KLEIMAN et al. ${ }^{69}$, 2003; KORANSKY; ROBBINS; BLAU ${ }^{70}, 2002$ ).

O fator de crescimento vascular endotelial (VEGF) é o regulador mais importante tanto da neovascularização fisiológica quanto da patológica. $O$ fato do VEGF ser um mitógeno relativamente específico para células endoteliais vasculares permite uma resposta angiogênica pronunciada numa variedade de modelos in vivo. O VEGF estimula as células endoteliais na degradação da matriz extracelular, migração e formação de túbulos in vitro. In vivo, o VEGF também funciona como regulador da permeabilidade vascular, que é considerada importante para o início da angiogênese. A sobrevivência de células endoteliais nos vasos recém- formados é VEGF-dependente. Coerente com seu papel na sobrevivência celular, o VEGF induz a expressão de proteínas anti-apoptóticas nas células endoteliais ${ }^{35,42,93,94,95}$.

VEGFR- 2 (Flk-1 ou KDR) é o receptor de maior importância no processo de angiogênese e aumento dos efeitos da permeabilidade do VEGF, estando o mesmo envolvido no processo de 
diferenciação das células endoteliais (NEUFELD et al. ${ }^{89}$, 1999; FERRARA ${ }^{35}$, 1999), quimiotaxia e sobrevivência celular (FERRARA; GERBER; LeCOUTER ${ }^{42}$, 2003).

Com base no conhecimento do papel do VEGF no processo de angiogênese $e^{35,93,108,42}$, e tendo-se o conhecimento da possibilidade de avaliar certos aspectos da angiogênese in vitro, nenhum estudo in vitro permite uma análise completa das etapas envolvidas no processo de revascularização tecidual.

Apoptose é essencialmente um suicídio celular, uma morte geneticamente programada em resposta a mecanismos fisiológicos e ou patológicos; a célula se auto destrói sem causar danos às células adjacentes. Essa conceituação foi descrita pela primeira vez na literatura por KERR et al ${ }^{66}$. 1972, no British Journal of Cancer e, a partir dessa publicação, inúmeros artigos vêm sendo publicados sobre esta temática ${ }^{56,62,84,92,114}$.

Sabe-se que a polpa dental de roedores como os ratos e camundongos respondem à terapia de modo significantemente diferente quando comparado à resposta da polpa humana. Por essa razão, a pesquisa baseada na implementação de fatias de dentes humanos (SLOAN et al. ${ }^{125}$, 1998; MURRAY et al. ${ }^{88}$, 2000) em subcutâneo de camundongos imunodeprimidos (SCID) pode ser um modelo de estudo animal ideal para estas averigüações, pois permitirá em futuros estudos um melhor entendimento do papel dos genes humanos específicos no processo de revascularização de polpas dentais humanas.

O objetivo primordial deste trabalho, portanto, é desenvolver um novo modelo de estudo, usando camundongos imunodeficientes para o estudo da angiogênese (NÖR et al. ${ }^{94}, 2001$; POLVERINI et al. $\left.{ }^{104}, 2003\right)$ da polpa humana. Além disso, verificar in vitro (cultura das fatias dentárias humanas), por meio da técnica de imunohistoquímica e teste do Tunel, o efeito do VEGF na angiogênese e na apoptose da polpa humana. 

2 REVISÃO DE LITERATURA 



\section{REVISÃO DA LITERATURA}

Este capítulo será dividido em alguns tópicos para um melhor entendimento. Primeiramente serão abordados conhecimentos gerais sobre angiogênese e terapia angiogênica, posteriormente 0 fator de crescimento vascular endotelial (VEGF) e, por último, a inclusão de uma pequena citação de trabalhos sobre a avulsão dentária, com o simples intuito de revisar alguns conceitos e mostrar diretrizes atuais dos trabalhos desenvolvidos na área de traumatismo dentário. A combinação e interligação dos conhecimentos sobre esses tópicos foi o "gatilho" para o desenvolvimento desta pesquisa.

\subsection{ANGIOGÊNESE}

Angiogênese é um processo fundamental para a formação de novos vasos sangüíneos a partir de capilares pre-existentes (CHAIN; JONES; TARNAWSKI ${ }^{19}$, 2004). É um evento importante em vários fenômenos fisiológicos tais como no desenvolvimento embrionário, inflamação crônica e no reparo tecidual (POLVERINI ${ }^{102}$, 1995). Levando-se em conta essas condições, angiogênese é altamente regulada, inicia-se sobre breves períodos (dias) e então é inibida completamente (FOLKMAN; SHING ${ }^{45}$, 1992). Entretanto, muitas doenças são ocasionadas pela persistência do processo de angiogênese, devido à neovascularização desregulada ${ }^{44,45}$.

A formação dos vasos sangüíneos ocorre por dois mecanismos diferentes, a vasculogênese e a angiogênese. Na vasculogênese ocorre a diferenciação de células endoteliais a partir de precursores mesodérmicos (angioblastos), manifestando-se somente durante o período embrionário, levando à formação de um plexo vascular primário. Com o tempo, esses canais endoteliais vão-se desenvolvendo formando um sistema mais complexo e se ramificando em vasos maiores e menores. Na angiogênese, os novos vasos são formados a partir de outros já existentes. Assim, novos capilares são formados, por meio da angiogênese, pela divisão dos vasos de 
origem (AUERBACH; AUERBACH ${ }^{7}$, 2002). Em adultos, a angiogênese é essencial para o ciclo reprodutivo feminino e para o reparo, remodelação e regeneração dos tecidos, por exemplo, durante o processo de cicatrização. Alguns fenômenos relacionados à angiogênese fisiológica são: a ovulação, desenvolvimento do corpo lúteo, embriogênese, amamentação, resposta imune, inflamação e a cicatrização (FOLKMAN; SHING ${ }^{45}$, 1992, POLVERINI ${ }^{102}$, 1995, AUERBACH; AUERBACH $\left.{ }^{7}, 2002\right)$.

Após os primeiros eventos migratórios, os estágios posteriores na formação da microcirculação incluem a expressão de citocinas específicas e fatores de crescimento pelas células endoteliais (POLVERINI ${ }^{102}$, 1995).

O processo de angiogênese é regulado por fatores de crescimento, citocinas pró-angiogênicas e inibidores da neovascularização. Mediadores angiogênicos podem ser divididos em 2 grupos: estimuladores e inibidores (POLVERINI ${ }^{102}$, 1995). A maioria das moléculas estimuladoras são proteínas e muitas delas são fatores de crescimento, moléculas de adesão celular, sinais de diferenciação, quimiotáxicos e enzimas que participam do controle da formação de um novo capilar (POLVERINI ${ }^{102}$, 1995, CARMELIET; JAIN $^{17}$, 2000, KERBEL ${ }^{65}$, 2000, TOMANEK; SCHATTEMAN ${ }^{135}$, 2000). Os inibidores fornecem o equilíbrio requerido para manter a população de células endoteliais inativa, porém altamente responsiva através de sinais anulados que, se ativados, podem levar a uma resposta angiogênica deletéria para o organismo. Eles são diversos em sua função e composição, agindo bloqueando ou atenuando a proliferação de células endoteliais, transdução sinalizadora, migração celular, expressão da metaloproteinase matricial, sobrevivência celular, desenvolvimento de precursor celular endotelial e ou recrutamento (POLVERINI ${ }^{102}$, 1995, CARMELIET; JAIN ${ }^{17}$, 2000, YANCOPOULOS et al. ${ }^{143}$, 2000).

Vasos sangüíneos capilares consistem de células endoteliais e pericitos. Estes dois tipos de células carregam toda a informação genética necessária para as ramificações, formação de tubos e redes capilares. Moléculas angiogênicas específicas podem iniciar este processo, enquanto que as moléculas inibitórias desempenham função contrária. Essas moléculas com funções opostas agem continuamente com $o$ intuito de manter a 
microvascularização quiescente. Entretando, as mesmas células endoteliais podem proliferar rapidamente (renovação de 5 dias) durante angiogênese, como por exemplo a que ocorre no processo de cicatrização (FOLKMAN; SHING ${ }^{45}$, 1992). Porém, nestes casos, o número de vasos formados será menor do que havia anteriormente (POLVERINI $\left.{ }^{103}, 2002\right)$. Já no processo de angiogênese, como no que ocorre no caso do endométrio, o número de vasos no final, será similar ao número que havia no início.

Fatores angiogênicos e inibidores têm sido investigados durante décadas quanto a suas propriedades, porém o estudo de suas interações está apenas começando a ser descoberto. O mesmo pode ser atribuído para as células não vasculares como os macrófagos, os quais podem modular a resposta angiogênica ${ }^{44,45}$.

Os fatores angiogênicos são classificados como direto e indireto. O fator angiogênico direto (aFGF, bFGF, IL-8 e VEGF) tem a função de estimular a proliferação das células endoteliais e ou migração das mesmas. Quando o fator angiogênico não estimula as células endoteliais in vitro, ele é chamado fator angiogênico indireto porque é assumido que a proliferação endotelial e migração, observada in vivo, deve ter sido induzida por algum outro fator ou célula, por exemplo o macrófago ${ }^{44,45}$. O macrófago, derivado de monócitos, além de reger o papel central na orquestra do processo de reparo (POLVERINI $\left.{ }^{102}, 1995\right)$, é responsável por coordenar a formação e remodelação do tecido durante o processo de cicatrização (POLVERINI $\left.{ }^{102}, 1995\right)$. Ele libera bFGF e VEGF, e sua atividade angiogênica ocorre em locais profundos do processo de cicatrização, quando a tensão de oxigênio é baixa e propícia para o metabolismo anaeróbico. A hipóxia que ocorre no centro do tumor é que propicia aos macrófagos tornarem-se angiogênicos (FOLKMAN; SHING ${ }^{45}$, 1992).

Recentemente, foram descritas substâncias genéticas conhecidas como angiopoietinas, apresentando-se sob quatro formas; porém só as formas $A_{n}$ e $_{1} \mathrm{Ang}_{2}$ são melhor conhecidas. Não são mitogênicas e ambas atuam em harmonia na regularização dos vasos. Ambas são ligantes para receptores $\mathrm{TIE}_{2}$, são úteis na formação endotelial, onde são abundantes. A $A_{n}{ }_{2}$ ativa o receptor $\mathrm{TIE}_{2}$, promovendo a fosforalização e estabilização vascular, principalmente nos adultos; é inibida pela hipóxia. A Ang 2 se liga à 
$\mathrm{TIE}_{2}$ por competição (sem ativá-la) e aparece nos tecidos em construção/ remodelação permitindo a livre ação do fator de crescimento vascular endotelial - VEGF (PONTUAL; MAGINI $\left.{ }^{105}, 2004\right)$.

Angiogênese é também o centro da etiologia e patogênese de inúmeros processos patológicos que incluem: tumores sólidos, doenças oculares, desordens inflamatórias como artrite reumatóide, psoríase e periodontite (POLVERINI $\left.{ }^{102}, 1995\right)$. Recentes estudos originados de vários laboratórios acreditam que nem todas angiogêneses e doencas vasodependente proliferativas são conseqüências de restrita produção normal ou anormal de mediadores pró-angiogênicos, mas também são resultados de uma deficiência relativa nas moléculas angiogênicas inibitórias. A coordenação e regulação da produção de fatores pró-angiogênicos e mediadores angiostáticos influenciarão no desenvolvimento da angiogênese e doenças ${ }^{102}$.

A neovascularização também desempenha um papel importante nos processos patológicos, como no crescimento tumoral e metástase (FERRARA; ALITALO ${ }^{40}$, 1999). O desenvolvimento de um tumor pode ser prolongado (semanas em ratos e anos em humanos). Durante este período o tumor não é angiogênico e está restrito ao crescimento em milímetros cúbicos. Quando células suficientes no interior do tumor adquirem fenótipo angiogênico, a neovascularização começa a surgir. A vascularização é necessária, mas não é suficiente para o crescimento rápido de um tumor primário e para a metástase destas células para órgãos distantes ( FOLKMAN; SHING ${ }^{45}$, 1992). A aquisição de atividade angiogênica pelos tumores parece ser um processo bastante complexo. Células tumorais liberam moléculas angiogênicas como VEGF, mas não está claro como essa liberação difere das células tumorais pré-angiogênicas ${ }^{45}$. As células tumorais recrutam novos vasos sangüíneos por diferentes mecanismos. Elas produzem fatores angiogênicos difusíveis os quais, diretamente, ativam as células endoteliais, fazendo com que as mesmas se difundam e cresçam com o desenvolvimento do tumor. Elas elaboram citocinas que atraem e ativam os macrófagos, mastócitos e neutrófilos, e estes elaboram fatores angiogênicos. A atividade angiogênica nas células tumorais pode ocorrer durante qualquer período durante a transformação neoplásica. Importante também é lembrar que a capacidade dos tumores de induzir angiogênese nem sempre pode ser correlacionada com o 
processo de malignidade do mesmo. Um exemplo disso é o tumor benigno (adenoma adrenal), que é altamente angiogênico, mas raramente se torna maligno (POLVERINI ${ }^{102}$, 1995).

O fator de crescimento vascular endotelial (VEGF) é um mitógeno potente para o endotélio vascular; modula a expressão de muitas enzimas proteolíticas envolvidas no processo de angiogênese. VEGF é capaz de regular todos os passos do processo de neovascularização e comumente ser importante nos processos fisiológicos e patológicos da angiogênese, no sistema reprodutivo feminino e em outros tecidos. VEGF é encontrado em muitas áreas em tecidos de adultos, indicando que ele é provavelmente importante não somente no processo de angiogênese, mas também no processo de manutenção de vasos existentes. VEGFR-1 (FIt-1) e VEGFR-2 (Flk-1; KDR) receptores de VEGF são essenciais para o desenvolvimento e diferenciação da vasculatura embrionária (CHARNOCK-JONES.; HE; SMITH ${ }^{20}$, 2002). No tópico 2.2 desta revisão de literatura dar-se-ão maiores informações sobre o mesmo.

\subsubsection{Terapia Angiogênica}

O ginecologista alemão Michael Hoeckel foi o primeiro a criar a expressão "therapeutic angiogenesis" - terapia angiogênica, em 1989, para descrever o processo de neovascularização para o tratamento ou prevenção de hipoperfusão local. Ele tem usado essa terminologia no contexto do processo de cicatrização e regeneração tecidual (WALTENBERGER; $\left.\mathrm{HOMBACH}^{141}, 2002\right)$.

Terapia angiogênica é uma técnica promissora que, baseada em estudos experimentais, demonstra que fatores de crescimento ou genes são capazes de aumentar a densidade capilar podendo, desse modo, ser essa técnica utilizada para reduzir o impacto da isquemia muscular e aumentar o fluxo sangüíneo para o tecido isquêmico, bem como auxiliar na formação de uma circulação colateral (BARANDON et al. ${ }^{10}, 2004$, GOUNIS et al. $\left.{ }^{48}, 2005\right)$. Essa técnica tem de ser vista como uma forma adjunta de 
tratamento às técnicas de revascularização cirúrgica (BARANDON et al. $^{10}$, 2004).

Sabe-se que o processo da angiogênese corresponde à reação das células endoteliais, que migram e proliferam no tecido isquêmico. $O$ tecido isquêmico produz fatores como o VEGF, responsável pela promoção da vasodilatação localizada, facilitando, assim, a migração da célula endotelial (CHAIN; JONES;TARNAWSKI ${ }^{19}$, 2004).

Numerosas proteínas têm a habilidade de intensificar $\mathrm{o}$ processo de angiogênese para compensar a isquemia do tecido. $O$ grande problema dessas proteínas é a meia vida curta, não disponibilizando as vantagens por um período de tempo mais prolongado. Um problema adicional é que o uso repetitivo da droga pode ocasionar uma resposta imune contra a mesma (BARANDON et al. $\left.{ }^{10}, 2004\right)$.

O fator de crescimento vascular endotelial (VEGF) é um dos fatores angiogênicos mais utilizados nos estudos de terapia angiogênica. No tópico VEGF, ações e propriedades há mais citações sobre a aplicabilidade do VEGF.

\subsection{FATOR DE CRESCIMENTO VASCULAR ENDOTELIAL -VEGF}

\subsubsection{Histórico}

\subsubsection{Fator de permeabilidade vascular (VPF)}

SENGER et al. ${ }^{117}$ (1983), por meio de estudos voltados para a identificação das propriedades fisiológicas dos vasos celulares tumorais, descreveram a purificação parcial de uma linha de células tumorais de cobaia, de uma proteína que promovia o aumento da permeabilidade vascular na pele com a potência 50.000 vezes maior do que a da histamina. Essa proteína foi denominada " fator de permeabilidade vascular endotelial" ( vascular permeability factor - VPF). Os autores concluíram, por meio desses estudos, que 0 VPF pode ser considerado um mediador específico da hiperpermeabilidade de vasos sangüíneos tumorais, e pode estar envolvido na formação de ascites associadas ao tumor. 
Como o VPF nao foi isolado e seqüenciado, permaneceu desconhecido naquela época. Poucos anos mais tarde, SENGER et al. ${ }^{118}$, 1990, relatou a purificação e o seqüenciamento terminal - NH2 de VPF da cobaia, proteína que foi inicialmente identificada. (RIBATTI $\left.{ }^{106}, 2004\right)$

\subsubsection{Fator de crescimento vascular endotelial (VEGF)}

Em junho de 1989, FERRARA; HENZEL ${ }^{41}$ relataram o isolamento de um mitógeno/ celular- endotelial específico, oriundo do meio que é condicionado pelas células foliculares pituitárias bovinas. Como esta proteína apresentou atividade promotora de crescimento somente em ação conjunta com as células endoteliais vasculares, ela foi denominada VEGF. A purificação e o seqüenciamento terminal- NH2 VEGF provou que essa proteína era distinta dos outros mitógenos celulares endoteliais já conhecidos, como o FGF2 (fator de crescimento fibroblástico), não possuindo semelhança alguma com nenhuma outra proteína já catalogada nas bases de dados. Subseqüentemente, o grupo de Conolly e colaboradores em 1989, relataram o isolamento e o seqüenciamento do VPF humano de uma linha celular tumoral (hepatocarcinoma) (KECK et al. ${ }^{64}$, 1989, RIBATTTI $\left.{ }^{106}, 2004\right)$.

Ambos os grupos, em dezembro de 1989, descreveram a clonagem cDNA do VEGF e VPF (KECH et al. ${ }^{64}$, 1989, LEUNG et al. ${ }^{72}$, 1989) tornando-se aparente que o VEGF e o VPF eram a mesma molécula. Pode-se ressaltar, desse modo, que os processos de mitogênese celular endotelial e de indução de permeabilidade vascular são mediados pelo mesmo fator.

VEGF/VPF possui uma homologia significante com PDGF (fator de crescimento derivado de plaqueta - platelet- derived growth factor") e com um outro membro da família de VEGF, denominado fator de crescimento placentário (PIGF) - $\left(\right.$ RIBATTI $\left.^{106}, 2004\right)$. O PIGF pode formar dímeros com o VEGF e, apesar de sozinho apresentar pouca atividade mitogênica ou de permeabilidade, torna-se capaz de potencializar significativamente a atividade de concentrações muito baixas de VEGF (RIBATTI ${ }^{106}$, 2004). PDGF e o VEGF atuam em células- alvos distintas e apresentam diferentes propriedades biológicas. 


\subsubsection{VEGF e suas isoformas}

O gene humano VEGF está organizado em oito exons separado por sete introns, estando localizado no cromossoma 6p21.3 (TISHER et al. ${ }^{134}, 1991$, VICENTI et al. $\left.{ }^{140}, 1996\right)$.

A família VEGF é composta de 7 membros. Cada membro da família é uma glicoproteína dimérica secretada, sendo conhecida como VEGF-A, VEGF -B, VEGF-C, VEGF-D, VEGF-E, VEGF- F e fator de crescimento placentário (PIGF) - HOEBEN et al. $\left.{ }^{53}, 2005\right)$.

VEGF A, comumente referenciado como VEGF, foi o primeiro a ser identificado por DVORAK et al. ${ }^{29}, 1995$, como um fator de indução da permeabilidade vascular secretado pelas células tumorais, sendo também referenciado como fator de permeabilidade vascular (VPF). VEGF A é uma glicoproteína homodimérica de $45 \mathrm{kDa}$ envolvida em uma séria de atividades angiogênicas (HOEBEN et al. ${ }^{53}, 2004$, HICKLIN; ELLIS ${ }^{52}, 2005$ ). O splicing alternativo do mRNA de um único gene envolvendo oito exons codifica inúmeras formas protéicas de VEGF com subunidades polipetídicas contendo 121, 165, 189 e 206 aminoácidos em humanos (RIBATTI ${ }^{106}, 2004$, HICKLIN; ELLIS $^{52}$, 2005). Além destas, algumas isoformas menos comumente expressadas têm sido identificadas como é o caso do VEGF 145 e VEGF 183 (NEUFELD et al. ${ }^{89}$, 1999, HICKLIN; ELLIS ${ }^{52}$, 2005). Atualmente, o VEGF 148 foi mencionado como mais uma isoforma protéica (HOEBEN et al. ${ }^{53}, 2004$ ). Segundo TAMELA et al. ${ }^{132}$, 2005, no mínimo 6 isoformas conhecidas são secretadas pela maioria das células.

A isoforma molecular mais predominantemente produzida por uma variedade de células normais, bem como células alteradas é o VEGF 165 (FERRARA $\left.{ }^{33,34,35}, 1996,1999\right)$, enquanto o VEGF 121 e o VEGF 189 são detectados na maioria das células e tecidos que expressam o gene VEGF. Em contraste, o VEGF 206 é uma forma rara. Já o VEGF145 é encontrado em várias linhas celulares tumorais de órgãos reprodutores femininos (PARK; KELLER; FERRARA ${ }^{98}, 1993$ ).

A matriz extracelular (MEC) das células que expressam o VEGF 189 ou VEGF 206 auxilia o crescimento de células endoteliais. Em contraste, a proteína VEGF é bioquimicamente indetectável na MEC das 
células que expressam o VEGF 121 e VEGF 165. Entretanto, a MEC derivada das células que expressam o VEGF 165, é capaz de estimular o crescimento das células endoteliais, mesmo em pequenas quantidades aderidas à matriz extracelular. A explicação para isso se deve ao fato de o VEGF 165 ser mais potente que as demais isoformas (PARK; KELLER; FERRARA ${ }^{98}$, 1993).

O VEGF 121 é uma proteína livremente difusível; em contraste, o VEGF 189 e VEGF 206 são seqüestrados na matriz extracelular e requerem a clivagem das proteases para a sua ativação (DVORAK $\left.{ }^{28}, 2002\right)$. Já o VEGF 165 existe em ambas as situações (HICKLIN; ELLIS ${ }^{52}$, 2005), e também secretado, embora uma fração significante se mantenha ligada à superfície celular e à matriz extracelular. O VEGF 165 apresenta as mesmas propriedades do VEGF original, que é considerado uma glicoproteína homodimérica de $45 \mathrm{kDa}$, básica e ligada à heparina (HOUCK et al. $\left.{ }^{54}, 1992\right)$. O VEGF 189 e VEGF 206 são mais básicos e se ligam à heparina com maior afinidade do que o VEGF 165.

As isoformas que são seqüestradas na matriz extracelular, como é o caso do VEFG A, VEGF C e VEGF D (isoformas envolvidas no processo de linfoangiogênese -TAMELA et al. $\left.{ }^{132}, 2005\right)$, podem ser liberadas em uma forma difusível pela plasmina seguida da clivagem na terminação - $\mathrm{COOH}$, gerando um fragmento bioactivo (HICKLIN; ELLIS ${ }^{52}$, 2005); com peso molecular aproximado de 34 kDa (HOUCK et al. ${ }^{54}$, 1992). Segundo HOEBEN et al. ${ }^{53}$ (2004), a plasmina está envolvida na degradação da matriz extracelular diretamente através da digestão dos componentes da membrana basal e indiretamente por ativação da colagenase através de zimógenos (proenzimas), resultando assim a liberação de VEGF-A 165, VEGFA 189 e VEGF- A 206.

Concluindo, então, temos duas formas possíveis de tornar as proteínas do VEGF disponíveis para as células endoteliais: pelo splicing alternativo gerando proteínas difusíveis como o VEGF 165, VEGF 121, ou pela ativação de proteases e clivagem das isoformas mais longas. (FERRARA ${ }^{38}$, 2002). 


\subsubsection{VEGF e seus receptores}

Receptores do tipo tirosina quinases (RTK) para o VEGF foram identificados e se apresentam de três formas: fms-like tyrosine-kinase-1 (denominado Flt-1) ou VEGFR-1, fetal liver kinase-1(Flk-1), kinase domain region (KDR) ou VEGFR-2 e o receptor VEGFR-3 mais conhecido como fmslike tyrosine kinase-4 (FIt-4) (FERRARA; GERBER.; LeCOUTER ${ }^{42}, 2003$, HOEBEN et al. ${ }^{53}$, 2004). VEGFR-1 e VEGFR-2 apresentam aproximadamente $44 \%$ de homologia. O VEGF se liga aos seus receptores utilizando quase que exclusivamente interações hidrofóbicas (FERRARA ${ }^{38}$, 2002). O VEGFR-1 e o VEGFR-2 são expressos na superfície da maioria das células endoteliais vasculares (sangüíneas), ao contrário do VEGFR-3 que se encontra restrito às células endoteliais linfáticas (FERRARA; GERBER.; LeCOUTER ${ }^{42}$, 2003). Cada isoforma da família VEGF possui diferentes especificidades de adesão a cada um dos receptores mencionados, auxiliando dessa maneira, a elucidar a função de cada um neste contexto (HICKLIN; ELLIS ${ }^{52}$, 2005). O VEGF-A se liga a ambos receptores VEGFR-1 e VEGFR-2. Em contraste, PIGF e VEGF-B interagem somente com o receptor VEGFR-1. VEGF-E (derivado do vírus Orf) é seletivo ao VEGFR-2. VEGF-C e VEGF-D se ligam aos receptores VEGFR-2 e ao VEGFR-3. Este não reconhece o VEGF-A. (FERRARA; GERBER.; Le COUTER $\left.{ }^{42}, 2003\right)$.

VEGFR-2 (Flk-1 ou KDR) é o receptor de maior importância no processo de angiogênese e aumento dos efeitos da permeabilidade do VEGF, estando o mesmo envolvido no processo de diferenciação das células endoteliais (NEUFELD et al. ${ }^{89}, 1999$, FERRARA $^{35}$, 1999), quimiotaxia e sobrevivência celular (FERRARA; GERBER; Le COUTER $^{42}$, 2003). O VEGFR-2 tem uma menor afinidade com o VEGF quando comparado ao VEGFR-1, porém uma maior atividade sinalizadora. O VEGFR-2 sofre uma fosforilação da tirosina e media a mitogênese, a migração celular e a permeabilidade vascular em resposta ao VEGF, enquanto que o VEGFR-1 apresenta fraca ou indetectável resposta ( FERRARA; GERBER; Le COUTER $\left.^{42}, 2003\right)$.

Em contraste, o receptor VEGFR-1 desempenha o papel de uma ligand-binding molécula no processo de angiogênese, em vez de um 
receptor transdutor de sinal. Ou seja, ele pode apresentar pouca ou nenhuma capacidade de transdução de sinal e simultaneamente ser capaz de regular a atividade do VEGF no endotélio vascular, impedindo a ligação do VEGF com o VEGFR-2 (PARK et al. ${ }^{99}$, 1994, FERRARA ${ }^{35}$, 1999). A ativação do receptor VEGFR-1 pode promover migração celular, porém a indução de proliferação celular não ocorre eficientemente (NEUFELD et al. ${ }^{89}$, 1999). O mesmo possui um significante envolvimento no processo de quimiotaxia monocitária (FERRARA; GERBER; Le COUTER ${ }^{42}$, 2003).

A função principal que ambos os receptores (VEGFR-1 e VEGFR-2) possuem no desenvolvimento do sistema vascular foi demonstrada em cobaias, em estudos desenvolvidos pelo grupo do Instituto Samuel Lunenfeld em Toronto, no ano de 1995. Através dessas pesquisas, pode-se observar que a eliminação dos genes relacionados a ambos os receptores Flt-1 ou Flk-1 em cobaias resultou em letalidade embrionária. Os embriões com a ausência dos genes vão à óbito antes do nascimento, devido ao fato de as células endoteliais não terem sofrido o processo de diferenciação e pela não ocorrência da formação dos vasos sanguíneos (FONG et al. ${ }^{46}$, 1995, SHALABAY et al. ${ }^{119}$ FERRARA $\left.{ }^{38}, 2002\right)$.

O receptor VEGFR-3 (FIt-4) está presente em todo o endotélio durante o processo de desenvolvimento, mas na fase adulta 0 mesmo restringe-se às células endoteliais. A expressão do VEGFR-3 é importante no início da formação dos vasos sangüíneos, tornando-se redundante tal função em vasos maduros (TAMELA et al. ${ }^{132}$, 2005). A ativação deste receptor estimula mitoses, migração, diferenciação e sobrevivência das células endoteliais linfáticas mediando, desse modo, o processo de linfangiogênese (HOEBEN et al. $\left.{ }^{53}, 2004\right)$.

As células endoteliais, bem como certos tumores (FERRARA; GERBER; Le COUTER ${ }^{42}$, 2003), expressam co-receptores para VEGF (não tirosina quinase, Neuropilina (Nrp-1-) SOKER et al. ${ }^{128}$, 1998) e Neuropilina (Nrp-2),(HICKLIN; ELLIS ${ }^{52}$, 2005) os quais ligam-se seletivamente à isoforma VEGF-165 (NEUFELD et al. ${ }^{89}$, 1999). Ambos estão envolvidos no processo imunológico e desenvolvimento neuronal, mas também assumem um papel importante no processo de angiogênese. (KLAGSBRUN; TAKASHIMA; MAMLUK ${ }^{68}$, 2002, BAGRI; TESSIER-LAVIGNE ${ }^{8}$, 2002, TAMELA et al. ${ }^{132}$, 
2005). Neuropilinas são glicoproteínas da superfície celular que se ligam aos mediadores semaforina/ colapsina de guia neuronal. Nrp-1 também se liga ao VEGF, VEGF-B e PIGF enquanto o Nrp-2 se liga ao VEGF, VEGF-C e PIGF. (KLAGSBRUN; TAKASHIMA; MAMLUK ${ }^{68}, 2002$, TAMELA et al. ${ }^{132}, 2005$ ). Nrp1 atua como co-receptor aumentando as interações VEGF-VEGFR-2, sendo sua expressão mais restrita a artérias, enquanto o Nrp-2 restringe-se a veias. (TAMELA et al. ${ }^{132}$, 2005). VEGFR-2 liga-se ao VEGF-165 mais eficientemente em células que expressam Nrp-1, (NEUFELD et al. $\left.{ }^{89}, 1999\right)$. Nrp-2 é também expresso em células endoteliais linfáticas. Mutações no Nrp-2 podem induzir anormalidades durante a formação de pequenos vasos linfáticos (TAMELA et al. $\left.{ }^{132}, 2005\right)$. Evidências recentes sugerem que o VEGF pode diretamente interagir com NRP sem a utilização dos receptores VEGFR-1 e VEGFR-2. (HICKLIN, ELLIS ${ }^{52}$, 2005). Na tabela 1 está o resumo das isoformas e receptores do VEGF.

Tabela A - Especificidade dos receptores ao ligante VEGF e efeitos biológicos.

\begin{tabular}{ccc}
\hline Membro da famíla VEGF & receptor & função \\
\hline VEGF (VEGF A) & $\begin{array}{c}\text { VEGFR-1, VEGFR-2, } \\
\text { neuropilina- 1 }\end{array}$ & $\begin{array}{c}\text { Angiogênese, } \\
\text { manutenção vascular }\end{array}$ \\
\hline VEGF B & VEGFR-1 & não estabelecida \\
\hline VEGF C & VEGFR-2, VEGFR-3 & linfangiogênese \\
\hline VEGF D & VEGFR-2, VEGFR-3 & linfangiogênese \\
\hline VEGF E (fator viral) & VEGFR-2 & angiogênese \\
\hline PIGF & VEGFR-1, neuropilina- 1 & $\begin{array}{c}\text { Angiogênese e } \\
\text { inflamação }\end{array}$ \\
\hline
\end{tabular}

PIGF = fator de crescimento da placenta

http://www.Anti-VEGF.com.br/publico/ciencia $1 \mathrm{htm}^{32}$.

\subsubsection{Ações e propriedades do VEGF}

VEGF é um mitógeno específico para as células endoteliais, produzido por vários tipos celulares, como queratinócitos, macrófagos, mastócitos e fibroblastos (NÖR et al. $.^{93}, 1999$, FERRARA ${ }^{39}$, 2004). 
O mesmo também é conhecido por aumentar a permeabilidade vascular e estar envolvido na ocorrência e progressão do processo inflamatório (DVORAK et al. $^{29}$, 1995). VEGF é 50.000 vezes mais potente do que a histamina na habilidade de aumentar a permeabilidade vascular (DVORAK ${ }^{28}, 2002$, HICKLIN; ELLIS $\left.{ }^{52}, 2005\right)$.

O VEGF desempenha um papel fundamental durante 0 processo de desenvolvimento, do reparo tecidual e para a manutenção da vida. Essa importância está vinculada à observação de que a inativação de um único alelo VEGF em cobaias resulta na letalidade embrionária entre os dias 11 e 12. (FERRARA $^{33}$, 1996, FERRARA ${ }^{38}$, 2002). O VEGF, porém, deixa de ser essencial para a sobrevivência quando as células endoteliais sofrem um processo de maturação, isso ocorrendo por volta da quarta semana pós-natal em camundongos (FERRARA ${ }^{35}$, 1999). Já no adulto plenamente desenvolvido, o VEGF passa a ser primariamente requerido para a ativação de processos angiogênicos como o desenvolvimento do corpo lúteo e processo de reparo (FERRARA $\left.^{35}, 1999\right)$.

O fator de crescimento vascular endotelial é a chave reguladora da angiogênese fisiológica durante o crescimento esqueletal e funções reprodutivas. Durante a embriogênese, o VEGF é essencial para a diferenciação de novos vasos sangüíneos. VEGF está também envolvido no processo de angiogênese no qual os novos vasos sangüíneos são formados a partir de outros vasos pré-existentes. Funciona como um potente fator prósobrevivência (anti-apoptótico) para células endoteliais em vasos recémformados. VEGF induz a expressão de proteínas anti- apoptóticas nas células endoteliais (FERRARA ${ }^{35}$, 1999). NÖR et al. ${ }^{93}$, em 1999, demonstraram que o VEGF induziu a expressão da proteína anti-apoptótica $\mathrm{Bcl}-2$, prolongando a sobrevivência da célula endotelial, bem como aumentando o processo de angiogênese. O VEGF estimula as células endoteliais na degradação de células endoteliais de matriz extracelular (MEC), migração e formação de túbulos in vitro.

O fator de crescimento vascular endotelial e seus receptores VEGFR-1 e VEGFR-2 (principal receptor mitogênico) desempenham um papel crítico no desenvolvimento do sistema vascular, via vasculogênese e mecanismos angiogênicos, como também na formação do 
sistema vascular linfático (TAMELA et al. $^{132}, 2005$ ). Posteriormente, estas mesmas moléculas são requeridas e envolvidas no reparo tecidual assim como no processo de cicatrização (NISSEN et al. ${ }^{90}, 1998$ ) e na reconstituição do endométrio feminino (TAMELA et al. ${ }^{132}, 2005$ ). O papel central que o VEGF apresenta mediando o processo de angiogênese durante o reparo tecidual foi observado em estudos desenvolvidos por NISSEN et al. ${ }^{90}$, em 1998, quando constataram que o VEGF é produzido e liberado localmente em áreas de cicatrização quando o crescimento de novos vasos é iniciado e mantido. Os mesmos autores observaram que a neutralização de VEGF diminui amplamente a atividade angiogênica e atividade quimiotática para células endoteliais nos fluidos do reparo tecidual. BOOTH et al. ${ }^{12}$, em 1998, relataram que o processo de cicatrização está associado com o aumento da produção de VEGF, porém em cobaias com diabetes este processo foi retardado, e a expressão VEGF no mRNA apresentou níveis mais baixos em comparação com o normal, sugerindo, desta forma, que um defeito na regulação do fator de crescimento vascular endotelial pode estar associado com as alterações no processo de reparo tecidual.

Outro aspecto relevante do VEGF é que o mesmo tem sua resposta altamente vinculada ao tipo de meio ambiente em que se encontra (POLVERINI ${ }^{103}, 2002$ ). A tensão de oxigênio bem como fatores de crescimento e citocinas são reguladores importantes do VEGF (HICKLIN; $\left.E L_{L I S}{ }^{52}, 2005\right)$. Condições de hipóxia desempenham um papel importante na regulação da expressão de uma variedade de genes. A expressão de VEGF mRNA é induzida por exposição a baixa tensão de oxigênio. Esta condição desempenha a função de recrutar vasos sangüíneos para áreas de tecido isquêmico (FERRARA $\left.{ }^{38}, 2002\right)$. Em contraste, condições de normóxia subregulam a produção de VEGF e promovem a regressão de vasos sangüíneos recém- formados. Quando as condições de hipóxia predominam, como no caso do crescimento tumoral, a expressão de VEGF persiste, potencializando, assim, o processo de angiogênese e, conseqüentemente, a progressão tumoral (SHWEIKI et al. ${ }^{120}$, 2002). Esse fator de crescimento vascular endotelial tem sido relacionado com a angiogênese patológica associada a tumores, alterações neovasculares intra-oculares e outras condições. FERRARA $^{35}$ (1999) suporta a hipótese de que o VEGF é o maior mediador da 
angiogênese associada com várias alterações. De fato, VEGF e seus inibidores constituem uma das melhores alternativas de tratamento para a inibição de tumores e alterações oculares.

Entretanto, numerosas questões ainda se encontram sem resposta, incluindo os mecanismos de transdução sinalizadora dos receptores de VEGF, em particular, o significado do receptor VEGFR-1 (FIt-1).

Algumas implicações clínicas interessantes do VEGF estão relacionadas ao seu envolvimento no processo de angiogênese óssea e formação óssea endocondral. A aplicação desse fator de crescimento vascular endotelial pode ser útil para melhorar o processo de revascularização em casos de fraturas não consolidadas e em outras condições (FERRARA; GERBER; LeCOUTER $^{42}$, 2003), como por exemplo, em casos de necroses ósseas (KATSUBE et al. $\left.{ }^{63}, 2005\right)$.

VEGF é continuamente considerado um fator central na regulação do processo de angiogênese, não sendo mais somente relacionado ao câncer (FERRARA ${ }^{38}$, 2002). Trabalhos como o de BOOTH et al. ${ }^{12}$, em 1998, demonstraram a presença do VEGF na doença periodontal inflamatória crônica, mas também, observaram a presença de VEGF em áreas livres de inflamação (periodonto saudável) ratificando o papel do mesmo na angiogênese fisiológica da gengiva e ambiente periodontal. A presença de VEGF na mucosa oral também foi observada por CARLILE et al. ${ }^{16}$, em 2001.

Estudos in vitro e em in vivo desenvolvidos por ROSENSTEIN et al. ${ }^{110}$, em 1998, demonstraram que o VEGF desempenha um papel crítico no desenvolvimento, controle e manutenção da angiogênese no cérebro.

O fator de crescimento vascular endotelial também tem sido utilizado como uma terapia alternativa para o tratamento de isquemias cardíacas em pacientes não aptos às técnicas de revascularização cirúrgicas (ELCIN; DIXIT; GITNICK ${ }^{31}$, 2001). Ambas as formas de administração da proteína recombinante humana- VEGF (ROSENSTEIN et al. ${ }^{110}$, 1998, FERRARA $^{35}$, 1999) e terapia genética têm sido utilizadas (FERRARA ${ }^{35}, 1999$, SIMONS; WARE ${ }^{123}, 2003$, BARANDON et al. ${ }^{10}$, 2004, KIM et al. ${ }^{67}, 2004$, KATSUBE et al. ${ }^{63}$, 2005, GOUNIS et al. ${ }^{48}$, 2005) para promover o 
desenvolvimento de uma circulação colateral (FERRARA ${ }^{35}$, 1999, FERRARA; ALITALO $^{40}$, 1999, HOEBEN et al. ${ }^{53}$, 2004).

Estudos pré-clínicos recentes, tanto em animais (GOUNIS et al. $^{48}$, 2004) como em pacientes (KIM et al. ${ }^{67}$, 2004), têm demonstrado resultados satisfatórios quando da utilização de terapia genética com VEGF no tratamento da doença arterial periférica (ELCIN; DIXIT; GITNICK ${ }^{31}$, 2001; KIM et al. ${ }^{67}$, 2004). A incidência dessa doença nos Estados Unidos da América é de mais de 300.000 pacientes novos por ano, sendo que o prognóstico para muitos desses pacientes é a espera para o momento da amputação do órgão lesado, usualmente envolvendo as pernas, pés e dedos (GOUNIS et al. ${ }^{48}$, 2004).

As aplicabilidades do VEGF citadas até o presente momento, neste capítulo, serviram como um impulso a estudos voltados à utilização desse fator de crescimento em outras áreas de concentração, especialmente na Odontologia.

\subsubsection{VEGF e a polpa dentária}

O fator de crescimento vascular endotelial foi e continua sendo um tópico muito estudado em diversas áreas da Medicina. $O$ conhecimento de suas propriedades e funções instigaram muitos pesquisadores a investigar o papel dessa proteína na área da Odontologia, principalmente nas especialidades voltadas para o estudo da polpa dentária.

A polpa dentária é um tecido conjuntivo frouxo, especializado, que contém células, fibras, substância fundamental, vasos sangüíneos e terminações nervosas. Ela encontra-se confinada em paredes rígidas de dentina formando com esta uma entidade embriológica e funcional, denominada como o complexo dentino-pulpar ( BERKOVITZ; HOLAND; MOXHAM $\left.^{11}, 2004\right)$.

Uma analogia do compartimento da polpa dental pode ser feita com o do nosso cérebro. Ambos os órgãos são confinados em uma estrutura rígida com paredes inexpansíveis, em que a expressão de VEGF, no caso do cérebro, resulta num aumento da pressão intracranial e, no caso da 
polpa dentária, resulta em aumento da sua pressão interna (HEYERAAS; BERGREEN $\left.{ }^{50}, 1999\right)$, pois sabe-se que o suprimento de sangue vem basicamente através de um pequeno forame apical. Esse forame apical é usado tanto para o suprimento sangüíneo como para a drenagem, ressaltando -se que o tecido pulpar nao possui suprimento sangüíneo colateral, tornando mais difícil a eliminação rápida do fluido filtrado. Levando-se em conta tais aspectos, esse sistema de eliminação deficiente do tecido pulpar propicia o desenvolvimento do quadro clínico de pulpite irreversível (MATSUSHITA et al. ${ }^{78}$, 1999). Em ambos os casos, o aumento da vascularização e permeabilidade mediada pelo VEGF pode contribuir para danos teciduais irreversíveis.

Angiogênese é um processo complexo que resulta na remodelação da matriz extracelular, secreção de enzimas proteolíticas, migração das células endoteliais, proliferação, diferenciação capilar e anastomoses (FOLKMAN ${ }^{43}$, 1995). Esse processo é regulado pela interação de inúmeras citocinas e fatores de crescimento (BOOTH et al. ${ }^{12}$, 1998). A expressão de VEGF é induzida por inúmeros mediadores inflamatórios, tais como a interleucina -6 , interleucina-1, prostaglandinas e, também, pela endotoxina (LPS)- lipopolissacarídeos, muitas das quais são encontradas na polpa dental (MIYAUCHI et al. ${ }^{83}$, 1995, GOODIS et al. ${ }^{47}$, 1997, STASHENKO; TELES, ${ }^{130}$ 1998, BOTERO et al. $\left.{ }^{13}, 2003\right)$.

A bactéria e seus produtos podem atingir a polpa dentária através dos túbulos dentinários estando, deste modo, envolvidas na patogenicidade da pulpite (LOVE; JENKINSON $\left.{ }^{74}, 2002\right)$.

MATSUSHITA et al. ${ }^{78}$, em 1999, investigaram, a partir de cultura de células, se a produção de VEGF pelas células pulpares poderia ser regulada por lipopolissacarídeos durante o processo de patogenicidade da pulpite. Esse estudo sugeriu que o aumento da produção de VEGF nas células pulpares humanas, induzido pelos lipopolissacarídeos, é dependente da sinalização do CD-14, o qual requer uma nova síntese de proteína, estando também relacionado em parte durante a ativação do fator de transcrição AP-1. Os autores sugeriram que o VEGF poderia induzir a permeabilidade vascular, proliferação, diferenciação das células pulpares a também estar relacionado com a quimiotaxia dos monócitos e macrófagos. Para isso, MATSUSHITA et 
al. ${ }^{79}$, em 2000, empenharam-se em minuciar o papel do VEGF nas células da polpa dental humana bem como no tecido pulpar. Os autores investigaram os efeitos do VEGF na quimiotaxia, proliferação e diferenciação das células da polpa dental humana. Eles observaram que o VEGF induziu uma resposta quimiotática bastante expressiva nas células da polpa dental humana, estando relacionada com a concentração (dose) administrada. Os resultados sugeriram que o VEGF foi produzido pelas células pulpares humanas atuando diretamente sobre as mesmas de uma forma autócrina. Além disso, constatouse que o VEGF pode promover quimiotaxia, proliferação e diferenciação através da utilização de um receptor contendo um domínio kinase (VEGFR-2 ) e, em parte, pela sinalização do fator de transcrição (AP-1) através da proteína c-fos, apesar de ambos os receptores (VEGFR-1 e VEGFR-2) estarem presentes nas células pulpares. MATTUELLA ${ }^{80}$, em 2005, avaliou, por meio de reação imuno-histoquímica, a presença ou a ausência do VEGFR-2 (vascular endothelial growth factor receptor-2) em células endoteliais pulpares de dentes decíduos e permanentes jovens humanos. Os resultados mostraram que tanto os dentes decíduos quanto os permanentes jovens apresentaram, especificamente, as células endoteliais pulpares imuno-marcadas para o VEGFR-2, sendo que uma intensidade maior da imunomarcação foi observada nos dentes decíduos.

MANTELLINE et al. $^{77}$, em 2003, observou elevados índices de expressão de VEGF em células pulpares. Esses achados sugerem que esse fator de crescimento desempenha um papel muito importante na vascularização da polpa dental. Foi observado, também, através desse estudo, que a resina adesiva e o HEMA (monômero hidrofílico) induzem a expressão de VEGF em macrófagos e odontoblastos, mas não em células indiferenciadas da polpa e em fibroblastos. Isso sugere que os odontoblastos assumem uma função importante na resposta angiogênica observada em polpas saudáveis, enquanto os macrófagos podem intensificar o processo de angiogênese quando a inflamação se encontra presente no tecido pulpar.

Recentemente, foi demonstrado que o ácido lipoteicóico (LTA), proveniente das paredes celulares das bactérias gram-positivas, pode elevar a expressão de VEGF em macrófagos e células pulpares (TELLES et al. ${ }^{133}$, 2003). Para entender melhor o funcionamento desse processo, 
SODEN ${ }^{127}$, em 2005, realizou um estudo in vitro no qual observou que o LTA (S. Sanguis) induziu a expressão de VEGF em células do tipo odontoblastos (MDPC-23) células indiferenciadas da polpa (OD-21) através da ativação de TLR2 (toll like receptors).

Muitos estudos estão sendo realizados para o melhor entendimento do fator de crescimento vascular endotelial na biologia da polpa dentária. A angiogênese na polpa dental é muito importante para o sucesso do reparo tecidual e pode ser dependente da liberação de fatores de crescimento nos locais em que está ocorrendo a reparação tecidual (SCHRODER $\left.{ }^{116}, 1985\right)$.

ROBERTS-CLARK; SMITH ${ }^{108}$ (2000) isolaram frações de matriz solúveis e insolúveis da dentina humana e mediram a quantidade de fatores de crescimento angiogênicos, dentre eles o VEGF, que foi encontrado em ambas as matrizes. Sendo assim, a matriz dentinária contém fatores de crescimento angiogênicos, os quais podem ser liberados após o processo de injúria, podendo desempenhar, desse modo, um papel importante no mecanismo de reparo no complexo dentino-pulpar. Tendo-se o conhecimento de que o VEGF está envolvido na atividade angiogênica durante a fase proliferativa do processo de reparação, cicatrização (NISSEL et al. ${ }^{90}$, 1998), a liberação do mesmo por meio da matriz dentinária pode contribuir para o processo de reparo da polpa dentária. O tecido pulpar, que se encontra inflamado, durante seu processo de recuperação necessita um suprimento sangüíneo suficiente e angiogênese.

ARTESE et al. $^{5,}$ 2002, utilizaram a técnica imunohistoquímica para verificar a expressão do VEGF e do fator VIII em células pulpares sadias e com pulpite irreversível. Os autores confirmaram a presença de VEGF em polpas normais com ausência de sinais inflamatórios sugerindose, desse modo, que o VEGF foi localmente produzido pelo tecido pulpar demonstrando, assim, a presença de uma angiogênese fisiológica na polpa dental.

DERRINGER; LINDEN²5, em 2003, relataram que a utilização de anticorpos neutralizadores (anti-h VEGF, FGF 2 , PDGF, TGF T $_{\mathrm{B}}$ e epidermal growth factor- EGF) permitiu avaliar a presença da combinação de cinco fatores de crescimento angiogênicos difusíveis na polpa dental humana durante a aplicação da força ortodôntica. Os resultados mostraram que ocorre 
a liberação da combinação dos fatores de crescimento angiogênicos na polpa dental durante a aplicação da força ortodôntica e que, na presença dos anticorpos (NAs), verificou-se a redução da resposta angiogênica, ou seja, houve uma diminuição do número de microvasos nas culturas de células estudadas, devido à inibição da liberação dos fatores de crescimento já mencionados. Em 2004, os mesmos autores observaram que todos os fatores de crescimento angiogênicos (VEGF, FGF 2 , PDGF e o TGF T $_{\mathrm{B}}$ ) examinados, tanto individualmente como em diferentes combinações, foram liberados após a aplicação de força ortodôntica, desempenhando um papel crítico na resposta angiogênica da polpa dentária e que os mesmos fatores podem ser mais efetivos quando estão associados.

O próximo capítulo desta revisão abrangerá alguns aspectos importantes sobre o tratamento ainda instituído atualmente para os casos de reimplante dentário podendo desse modo, esclarecer o interesse do estudo da aplicabilidade do VEGF na revascularização pulpar em casos de avulsão dentária.

\subsection{AVULSÃO DENTÁRIA}

Segundo as estatísticas, o traumatismo dentário acomete pacientes jovens na faixa etária de 7 a 11 anos, envolvendo os incisivos centrais e laterais superiores, os quais, na maioria das vezes, encontram-se ainda em fase de desenvolvimento radicular (risozênese incompleta) ${ }^{1,2,3,4}$.

Autores como EBELESEDER et al. ${ }^{30}$, 1998, sugerem que o reimplante dental deve ser considerado um tratamento temporário em crianças e adolescentes. A conduta clínica preconizada em situações de rizogênese incompleta é a espera da revascularização do tecido pulpar proporcionando, dessa maneira, condições para a complementação do desenvolvimento radicular.

Vários estudos foram realizados na área de traumatismo dentário, mas a maioria deles são direcionados para a tentativa de descoberta de alguma substância que fosse capaz de evitar a reabsorção externa radicular 
e anquilose alvéolo-dentária, conseqüências essas da maioria dos casos de avulsão. Trabalhos como os de ÇAGLAR; TANBOGA; SUSAL ${ }^{15}, 2005$ e de SCHJOTT; ANDREASEN ${ }^{115}$, 2005, ressaltam a utilização do Emdogain (matriz de esmalte dentária) no tratamento de dentes avulsionados, enquanto os trabalhos de ÇAGLAR; TANBOGA; SUSAL ${ }^{15}$, 2005, mostraram resultados satisfatórios com a utilização do Emdogain no que se refere ao processo de cicatrização periodontal. Os resultados de SCHJOTT; ANDREASEN ${ }^{115}, 2005$ demonstraram que o Emdogain não foi capaz de evitar e recuperar áreas previamente anquilosadas, conseqüência essa, do tratamento de dentes avulsionados.

Outra substância derivada dos biofosfanatos de terceira geração (Alendronato) também tem sido amplamente investigada para o tratamento de dentes avulsionados devido ao seu poder inibitório da atividade osteoclástica, sugerindo-se que a mesma possa desacelerar o processo de reabsorção instalado após injúrias traumáticas severas (LEVIN et al. ${ }^{73}, 2001$ ). $\mathrm{MORI}^{85}$, em 2005, monstrou que tanto as soluções de alendronato e nitrato de gálio como a pasta de hidróxido de cálcio limitaram a reabsorção dentária, mas não impediram o aparecimento da mesma. Já com o uso de acetazolamida, a reabsorção radicular esteve ausente aos 60 dias, comprovando a sua eficácia na inibição da reabsorção radicular.

Segundo a American Association of Endodontics (A. A. E.) ${ }^{1}$, o fluoreto de sódio (em concentração entre 1 a 2,4\% por 20 minutos), devido ao fato de reduzir a severidade da reabsorção dentária, é o medicamento de escolha para o tratamento de superfície de dentes avulsionados e reimplantados tardiamente.

O meio de conservação ideal para a armazenagem dos dentes avulsionados tem sido alvo, também, de inúmeros estudos (JOHNSON et al. ${ }^{60}, 1985$, PETTIETTE et al. ${ }^{101}, 1997$, DOYLE; DUMSHA; SYDISKIS ${ }^{27}$, 1998. ASHKENAZI; SARNAT; KEILA ${ }^{6}, 1999$, BUTTKE; TROPE ${ }^{14}, 2003$ ), porém ainda hoje tem-se indicado o leite como o meio de conservação mais utilizado em casos de reimplante, por não se ter acesso tão facilmente à solução balanceada de Hanks, conhecida comercialmente como Save a Tooth, indicada pela Associação Americana de Endodontia (AAE) ${ }^{1}$ no seu protocolo de tratamento de dentes avulsionados. (SIGALAS et al. ${ }^{122}$, 2004). 
Encontramos alguns trabalhos na literatura voltados ao estudo da revascularização pulpar, principalmente direcionados ao tratamento de dentes avulsionados com rizogênese incompleta ${ }^{23,24}$. CVEK et al. $^{23} \mathrm{em}$ 1990, concluíram, através de análises microscópicas, que o efeito do tratamento tópico com doxiciclina em dentes com ápice incompleto, extraídos de macacos, previamente ao reimplante, foi o maior responsável pela redução do número de microrganismos da superfície radicular contaminada durante o período extra-alveolar, aumentando a freqüência da revascularização. Resultados semelhantes foram relatados por YANPISET; TROPE ${ }^{144}$, em 2000, com a utilização da doxiciclina, previamente ao reimplante dentário, porém o estudo foi realizado em dentes de cães com ápice incompleto. Já RITTER et al. $^{107}$, em 2004, compararam o efeito da aplicação da doxiciclina com o da minociclina no tratamento da revascularização pulpar em dentes de cães com rizogênese incompleta. Concluíram, através da análise microscópica, que a minociclina foi mais eficiente no auxílio à revascularização pulpar do que a doxiciclina.

A revascularização após a criopreservação e o autotransplante de dentes de cães com risogênese incompleta e dentes apicectomizados com ápice fechado foram alvos do estudo de LAUREYS et al. ${ }^{71}$, em 2001. Nesse estudo os autores, através de seus resultados, demonstraram que a revascularização pode ocorrer após o autotransplante se a polpa original for removida no momento da extração dentária. Não houve diferenca significante na quantidade de revascularização entre dentes armazenados no banco de dentes por 7 dias e aqueles imediatamente transplantados sem o congelamento. Também não houve diferença, no que se refere ao crescimento, de um novo tecido pulpar entre os dentes com ápice fechado e apicetomizados e os com rizogênese incompleta. CLAUS et al. ${ }^{21}$, em 2004 , também seguiram a mesma metodologia, porém sem a técnica da criopreservação. Os autores demonstraram que ocorreu a invaginação de um tecido conjuntivo rico em células e altamente vascularizado nos dentes transplantados com rizogênese incompleta após a remoção do tecido pulpar original no momento da extração. Ambos os trabalhos mais atualizados seguiram as publicações de SKOGLUND; TRONSTAD ${ }^{124}, 1981$. 
Já existem outras pesquisas que apresentam 0 monitoramento da vitalidade pulpar após o transplante de dentes com ápice completo. SIERS; WILLEMSEM; GULABILAVA ${ }^{121}$, em 2002, obtiveram revascularização em dentes autotransplantados com rizogênese completa, após o acompanhamento de 26 meses; obtiveram obliteração do espaço pulpar sem evidência de patologia no ligamento periodontal.

BANCHS; TROPE ${ }^{9}$, em 2004, propuseram uma nova técnica para revascularização de dentes com ápice incompleto portadores de lesão periapical. O canal foi desinfectado com irrigação de 5.25 hipoclorito de sódio, e uma pasta composta de 3 antibióticos (ciprofloxacin, metranidazol, minociclina) foi inserida $8 \mathrm{~mm}$ no interior do canal radicular. Após o protocolo de desinfecção, o ápice foi mecanicamente irritado, proporcionando um sangramento para o interior do canal com a intenção de produzir um coágulo ao nível da junção cemento-esmalte. Selamento duplo com MTA foi realizado, associado à aplicação de resina adesiva. Todos os fatores em combinação produziram um ambiente favorável ao sucesso da revascularização.

São estas as recomendações da American Association of Endodontics (A. A. E) ${ }^{1}, 2004$, de acordo com o tempo extra-alveolar: se o dente permanecer por mais de 1 hora fora do alvéolo, em meio seco, a endodontia deve ser realizada antes do reimplante; já se o tempo não exceder 1 hora, deve-se considerar a possibilidade de revascularização em dentes com rizogênese incompleta; todavia em dentes com ápice completo faz-se a endodontia dentro de 7 a 14 dias após o reimplante.

Os trabalhos citados nesta breve revisão demonstram que ainda há a necessidade de obtenção de um modelo de estudo que possibilite condições adequadas para um melhor entendimento do processo de angiogênese da polpa dental, principalmente nos casos de reimplante de dentes com risogênese incompleta, para os quais se aguarda o processo de revasculariazação, e que a utilização de fatores angiogênicos no tratamento da avulsão dentária ainda não foi temática investigada. Por essa razão, este estudo foi desenvolvido com tais finalidades. 
3 PROPOSIÇÃO 



\section{PROPOSIÇÃO}

Esta pesquisa tem o propósito de avaliar, por meio da análise microscópica, imuno-histoquímica e do sistema de detecção de células apoptóticas (teste do Tunel) os seguintes objetivos específicos:

1. Desenvolvimento de um novo modelo de estudo para a avaliação dos processos de revascularização da polpa dental.

2. Efeito da aplicação direta da proteína recombinante humana VEGF 165 , na polpa dental humana mantida em condições de cultura celular por 7 dias, na revascularização da mesma e na manutenção da vitalidade tecidual . 

4- MATERIAIS E MÉTODOS 



\section{4- MATERIAIS E MÉTODOS}

Para a realização desta pesquisa desenvolveu-se um novo modelo de estudo da angiogênese da polpa humana. Esse novo modelo de estudo combinou princípios básicos de outras duas metodologias já publicadas. Uma das metodologias se refere às publicações do Dr. Anthony Smith (SLOAN et al. $\left.{ }^{125}, 1998\right)$, a qual possibilitou a habilitação necessária para a realização da primeira etapa do trabalho, o experimento in vitro. Seus estudos envolvem a utilização de modelos de cultura, usando fatias de dente para o estudo da polpa dental (McLACHLAN; SMITH; COOPER ${ }^{81}, 2003$, MURRAY et al. ${ }^{88}, 2000$,

SLOAN et al. $\left.{ }^{125}, 1998\right)$. A metodologia empregada para a indução da vascularização em camundongos imunodeprimidos seguiu as investigações desenvolvidas e publicadas pelo Dr. Jacques Nör e colaboradores em seu laboratório ${ }^{94,104}$.

Este trabalho foi realizado em três etapas: primeiramente realizou-se um estudo-piloto (Apêndice) para a avaliação da viabilidade da execução do projeto in vitro, bem como para definir a metodologia no que se relaciona à obtenção e cultura das fatias dentárias; o estudo in vitro também englobou cultura celular e análises de RT-PCR. Posteriormente à realização do projeto in vitro, efetuou-se o desenvolvimento do estudo in vivo.

\subsection{ESTUDO IN VITRO}

\subsubsection{Cultura de células}

Realizou-se a cultura das linhas celulares citadas subseqüentemente para posterior extração do RNA e realização da técnica de transcrição reversa - reação em cadeia de polimerase (RT- PCR). Células pulpares indiferenciadas de camundongo (OD-21 - (HANKS et al. $\left.{ }^{49}, 1998\right)$, células tipo odontoblasto de camundongo (MDPC-23 - HANKS et al. $\left.{ }^{49}, 1998\right) \mathrm{e}$ macrófagos de camundongo (RAW 264.7, ATTCC, Manassas, VA, USA) foram 
mantidas em meio de cultura (Dulbecco's Modified Eagle Medium, DMEM, Gibco, BRL, Grand Island, NY, USA) suplementado com soro bovino fetal a 10\% (Gibco), 200mM L- Glutamine (Gibco), 125 unidades/mL de penicilina (Gibco) e 125 unidades/ mL de estreptomicina (Gibco). Células endoteliais da microvasculatura da derme humana (HDMECs - Cell Sytems Corp., Kirkland, WA) cresceram em meio de cultura EGM2- MV (Endothelial Cell Growth Medium, Clonetics Corp., San Diego, CA). A cultura das células foi realizada em uma incubadora com $5 \%$ de $\mathrm{CO} 2$ a $37^{\circ} \mathrm{C}$.

\subsubsection{Transcrição reversa - reação em cadeia de polimerase (RT- PCR Semiquantitativo)}

RT-PCR foi usado para avaliar a expressão do receptor VEGFR-2 mRNA nas células pulpares indiferenciadas de camundongo-OD-21 (HANKS et al. ${ }^{49}$, 1998), células tipo odontoblasto de camundongo - MDPC-23 (HANKS et al. ${ }^{49}$, 1998), macrófagos de camundongo (RAW 264.7, ATTCC, Manassas, VA, USA) e nas células endoteliais da microvasculatura da derme humana- HDMECs (Cell Sytems Corp., Kirkland, WA). RNA total das células OD-21, MDPC-23, macrófagos e HDMECs (controle positivo) foi extraído utilizando-se o sistema RNAeasy Mini Kit (Qiagen, Valencia CA, USA) de acordo com as instruções do fabricante.

Receptor 2 do fator de crescimento vascular endotelial (VEGFR-2) e gliceraldeído adenosina fosfato desidrogenase (GAPDH) primers delineados foram combinados com Super Script one step RT-PCR with Platinum Taq kit (Invitrogen, Carlsbad, CA, USA) para a síntese de cDNA e amplificação de PCR, seguindo as orientações do fabricante. A síntese de cDNA e desnaturação foram realizadas incubando o molde de RNA (200ng por amostra), $0.2 \mu \mathrm{M}$ de primer sense, $0.2 \mu \mathrm{M}$ de primer anti-sense ,0.2 $\mu \mathrm{M}$ dNTP, $1.2 \mathrm{mM}, \mathrm{MgSO}_{4}$ e $1 \mu \mathrm{l}$ de RT/ Platinum Taq Mix em uma reação de volume de $50 \mu \mathrm{l}$ por $30 \mathrm{~min}$ na temperatura de $55^{\circ} \mathrm{C}$, e logo após por mais $2 \mathrm{~min}$ na temperatura de $94^{\circ} \mathrm{C}$ em um Master cycler Gradient thermocycler ( Eppendorf, Hamburg, Germany). Foram utilizados 35 ciclos de amplificação da PCR 
consistindo de desnaturação $94^{\circ} \mathrm{C}$ por $30 \mathrm{~s}$, anelamento $55^{\circ} \mathrm{C}$ por $30 \mathrm{~s}$, polimerização $72^{\circ} \mathrm{C}$ por $1 \mathrm{~min}$, e a fase de extensão final de incubação foi realizada na temperatura de $72^{\circ} \mathrm{C}$ por $10 \mathrm{~min}$.

Os primers VEGFR-2 usados (tanto para humanos como para camundongos) foram os seguintes: sense, 5'CTCATGTCTGAACTCAAGATCC-3'; anti-sense, 5'CCAGAATCCTCTTCCATGCTC A- 3' (Invitrogen), com um produto de tamanho esperado de 928bp. GAPDH (humano/ camundongo) com 683bp foi usado como controle interno para o carregamento e amplificação da PCR. Os primers GAPDH (humano/ camundongo) utilizados foram: sense, 5'GACCCCTCCATTGACCTAAACT- 3'; e anti-sense, 5'CACCACCTTCTTGATGTCATC- 3'. Os produtos do RT-PCR foram analisados por eletroforese em géis de agarose a 1\% contendo brometo de etídeo numa voltagem de $80 \mathrm{kv}$. Os géis foram fotografados com uma câmara gel Polaroid (Kodak) sobre tela transiluminadora ultravioleta (Spectroline, Westburg, NY, USA). Os dados apresentados são representativos de três experimentos independentes. Informações adicionais para o protocolo de extração de RNA total estão descritas no capítulo Apêndice.

\subsubsection{Coleta, preparação das fatias de dente e cultura}

As fatias dentárias (16) foram preparadas utilizando terceiro molares (superiores e inferiores) ou pré-molares hígidos, os quais foram previamente extraídos por razões ortodônticas, na Unidade de Cirurgia Oral da Universidade de Odontologia de Michigan (aprovada pelo comitê de ética da Universidade de Odontologia de Michigan para pesquisas envolvendo seres humanos= projeto IRB HO3-00001606-I).

Os espécimes foram coletados em um meio de cultura estéril a $37^{\circ} \mathrm{C}$, usado somente para o transporte do espécime até a área de intervenção do mesmo (Dulbecco's Modified Eagles's Medium - DMEM, Sigma Chemical Co, contendo $5 \mathrm{~mL}$ de L-Glutamine- 200mM (Gibco), suplementado com $5 \mathrm{~mL}$ de 10.000 unidades de penicilina, $10 \mathrm{mg} / \mathrm{ml}$ de estreptomicina $(100 \mathrm{x}$ 
dilution/stock pen/strep - Gibco) e 1.25 mg de anfotericina B (Sigma, St. Louis, MO-USA). O meio no qual as fatias dentárias foram mantidas durante o período experimental (tooth culture media) foi o DMEM, preparado contendo $20 \%$ de soro bovino fetal inativado (Gibco), $5 \mathrm{~mL}$ de L-Glutamine- 200mM, suplementado com solução de penicilina/ estreptomicina na concentração de $1 \%$ (contendo 10.000 unidades de penicilina, $10 \mathrm{mg} / \mathrm{ml}$ de estreptomicina), 1.25 $\mathrm{mg}$ de anfotericina B e $0.15 \mathrm{mg} / \mathrm{ml}$ of vitamin C (Sigma). Após a extração, as amostras foram levadas no interior de um tubo de ensaio de $15 \mathrm{ml}$ (Denville Scientific Inc. New Jersey, USA) contendo o meio de transporte até a área de intervenção. Todos os procedimentos foram realizados no interior de uma capela de fluxo contínuo.

O excesso gengival, ligamento periodontal foi removido raspando-se delicadamente a superfície externa dos dentes recém-extraídos com o auxílio de uma cureta periodontal Gracey (Maillefer). Em seguida, os dentes foram desinfectados utilizando-se uma gaze estéril umedecida com etanol 70\% (AAper Alcohol and Chemical Company, Kentucky, USA).

Procedeu-se, então, à fixação do dente com resina acrílica ativada quimicamente, em um suporte de madeira já autoclavada. Somente a região do ápice e da coroa foram cobertas com resina acrílica (Selfcure resin, SNAP- Parkell-Bio -Materials), deixando-se livre toda porção radicular para otenção das fatias dentárias. Quando da utilização de molares, optou-se pelo uso da raiz de maior volume deixando-a livre para o corte; assentaram-se as demais raízes com uma camada de resina à madeira. Aguardaram-se $5 \mathrm{~min}$ para a completa estabilização do conjunto dente/resina/madeira. Em seguida, prosseguiu-se com a colocação do conjunto no braço da máquina de corte - Isomet Low speed Saw (Model 650, South Bay Technology, INC. Japan) para realização dos cortes (Figura 1). 

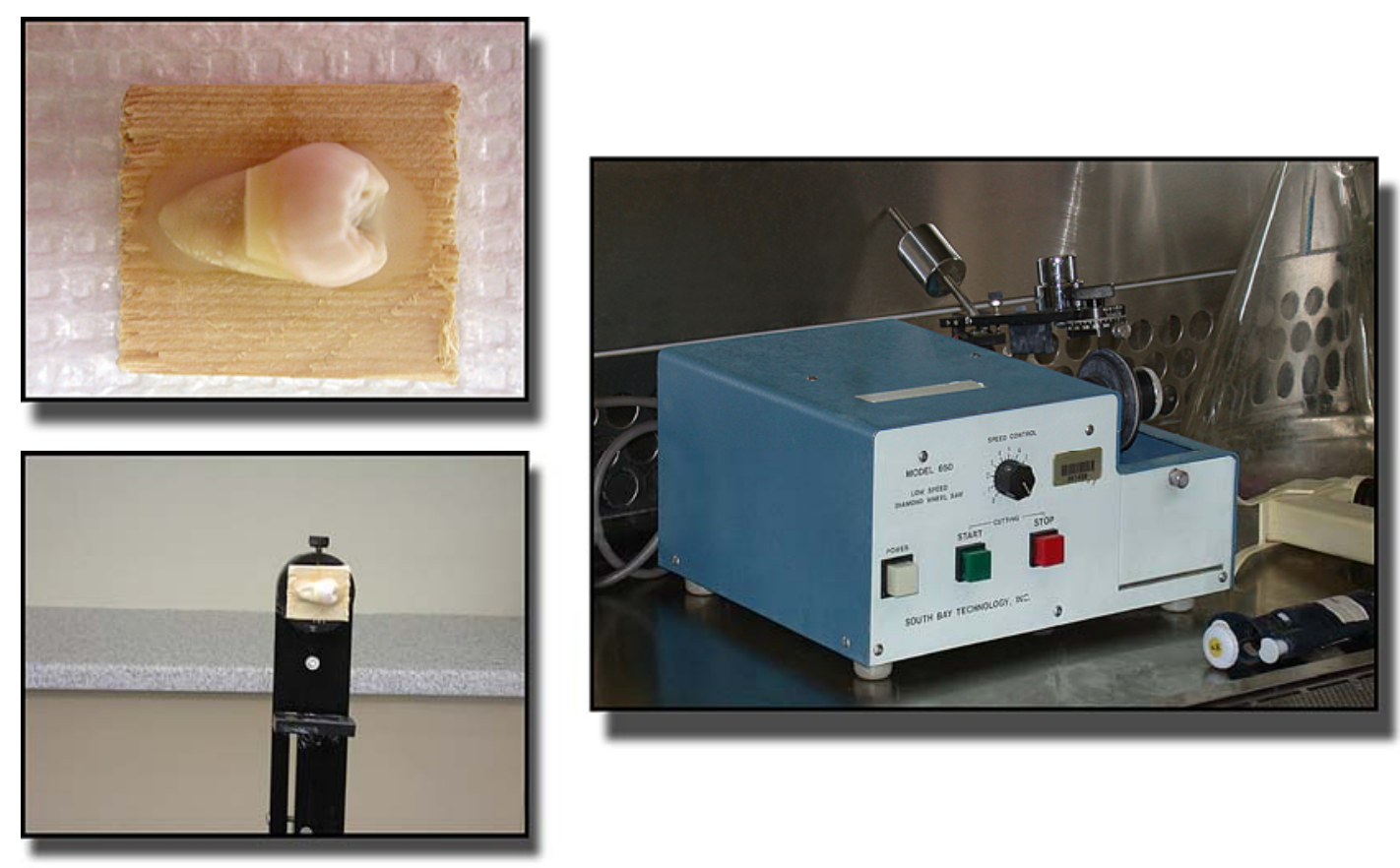

Figura 1- Estabilização do dente e adaptação na máquina de corte (Isomet).

Deu-se início ao preparo das fatias dentárias de $1.5 \mathrm{~mm}$ de espessura, cortadas transversalmente com o auxílio de um disco de corte diamantado (MK- 303 professional- MK DIAMOND PRODUCTS INC. Torrance, CA) acoplado à máquina de corte de baixa velocidade (Isomet, INC. Japan) sob refrigeração com a solução salina estéril (PBS 1X - phosphate buffered saline, Cellgro- Mediatech, Inc. Herndon, VA). Estipulou-se a obtenção de 2 fatias dentárias por dente para a realização do experimento (Figura 2). 


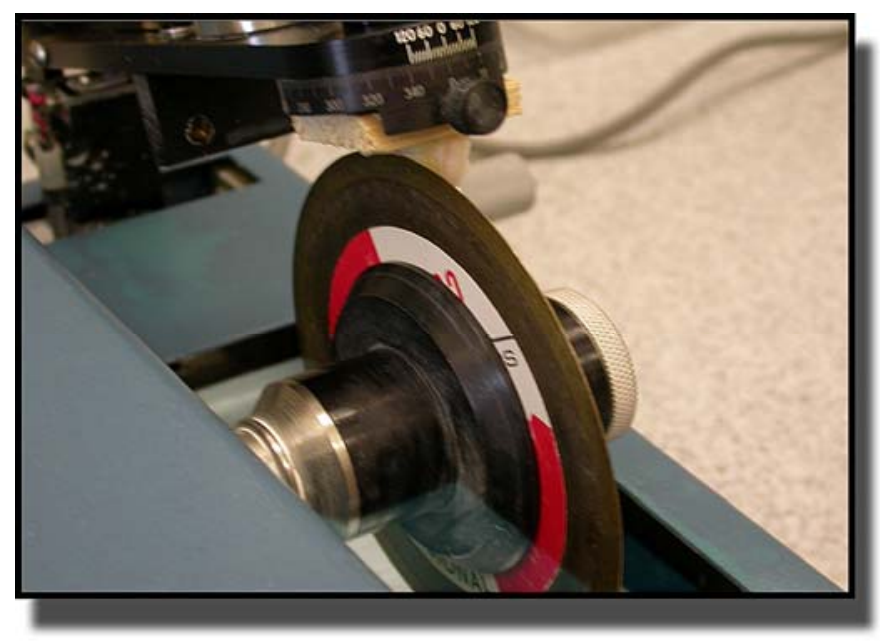

Figura 2. Preparação das fatias dentárias

A desinfecção do disco de corte foi mantida com pequenos jatos de spray de etanol 70\% (AAper Alcohol and Chemical Company, Kentucky, USA) durante todo procedimento de obtenção das fatias dentárias. A máquina de corte foi mantida, previamente a sua utilização, por 30min sob luz ultravioleta no interior da capela de fluxo contínuo para a sua descontaminação. Todos os instrumentos, bem com os discos utilizados, foram esterilizados em autoclave.

Cada fatia dentária obtida foi imersa previamente à cultura, em 12-well plates (placa com 12 reservatórios individuais- BD Falcon, BD Biosciences) contendo $1 \mathrm{ml}$ do meio de cultura de transporte das fatias dentárias. Em seguida, as fatias dentárias foram divididas em 2 grupos, conforme a tabela 2 .

Tabela B - Distribuição dos Grupos

\begin{tabular}{c|c|c|c}
\hline Grupos & $\begin{array}{c}\mathbf{N}^{\circ} \text { de fatias } \\
\text { dentárias }\end{array}$ & $\begin{array}{c}\text { Meio de cultura } \\
\text { das fatias } \\
\text { dentárias }\end{array}$ & Concentração \\
\hline Controle & 8 & sem VEGF & 0 \\
\hline Experimental & 8 & com VEGF & $50 \mathrm{ng} / \mathrm{ml}$ \\
\hline
\end{tabular}

As fatias dentárias foram mantidas em cultura a $37^{\circ} \mathrm{C}$ na atmosfera de $100 \%$ de $\mathrm{H}_{2} \mathrm{O} / 5 \%$ de $\mathrm{CO}_{2}$ durante o período de 7 dias. $\mathrm{O}$ meio de cultura (tooth culture medium) para as fatias dentárias foi trocado a cada 2 
dias, sendo que para o grupo experimental adicionou-se a ele $50 \mathrm{ng} / \mathrm{ml}$ da proteína recombinante humana (VEGF-165, R\&D Systems), descongelada minutos antes do seu uso. No grupo experimental, cada fatia foi mantida em 12-well plates (placa com 12 reservatórios individuais - BD Falcon, BD Biosciences) em reservatório individual contendo $1 \mathrm{ml}$ do meio de cultura (tooth culture medium) associado a $1 \mu \mathrm{l}$ de VEGF $(50 \mu \mathrm{g} / \mu \mathrm{l})$.

\subsubsection{Processamento Laboratorial}

Após 7 dias de cultura, as amostras in vitro foram identificadas e imersas em tubos de plásticos individuais de $15 \mathrm{ml}$ (Denville Scientific Inc. New Jersey, USA) contendo $5 \mathrm{ml}$ de solução de formalina tamponada a $10 \%$ (Fisher Scientific) por um período de $24 \mathrm{~h}$ sob refrigeração a $4^{\circ} \mathrm{C}$ para a fixação do tecido pulpar. Após esse período, os espécimes foram submetidos ao processo de desmineralização utilizando o ácido fórmico a 10\% (Fisher Scientific) pelo período de 48h. O período de fixação e desmineralização foi o mesmo para o estudo in vivo.

Após a constatação do término da desmineralização, por meio da ausência de resistência ao corte, as amostras foram submetidas aos processos histotécnicos e incluídas em parafina. Foram realizados cortes de $7 \mu \mathrm{m}$ (rotina do laboratório de histologia e patologia da Universidade de Odontologia de Michigan) e os mesmos foram corados com hematoxilina e eosina para análise em microscópio de transmissão de luz.

O estudo in vitro e o estudo in vivo, relatado na sequência, receberam o mesmo processamento laboratorial para a confecção das lâminas de coloração para HE.

Obtiveram-se cortes seriados de $5 \mu \mathrm{m}$ e os mesmos posicionados sobre lâminas de vidro previamente carregadas (+) (Dako, S3003, Carpintaria, CA). Uma lâmina de cada fatia foi corada com HE para verificar a viabilidade do tecido pulpar. A partir deste momento, foram realizadas mais três lâminas de cada amostra, contendo três cortes seqüenciais em cada uma. As lâminas submetidas à reação imuno-histoquímica (Dako) foram aquecidas em 
estufa a $37^{\circ} \mathrm{C}$ durante 1 hora, enquanto as destinadas ao teste de Tunel assay $^{55}$ (Roche- Penzberg, Germany) foram incubadas em estufa a $60^{\circ} \mathrm{C}$ por 30 minutos.

\subsubsection{Técnica Imuno-histoquímica}

A técnica de imuno-histoquímica foi realizada usando o kit da DAKO Cytomation EnVision + System-HRP (AEC) utilizando anticorpo policlonal primário, Fator de von Willebrand (Fator VIII related antigen Ab-1 Rabitt Pab ref. RB-281-A, NeoMarker Fremont, CA); antibody diluent - ref. S0809, 1:500), seguindo o seguinte protocolo:

1. Pré-aquecimento das lâminas por 1 hora à temperatura de $59^{\circ} \mathrm{C}$.

2. Desparafinização em xilol ( três trocas de 3 minutos cada).

3. Reidratação por meio de trocas graduais de álcoois 100\%, 95\% e $70 \%$ (2 minutos cada).

4. Lavagem em água destilada, duas vezes.

5. Recuperação Antigênica (Target Retrievel Solution, Dako, Code S1699, Carpintaria, EUA) : mistura de $2 \mathrm{ml}$ da solução recuperadora (retrievel solution- 10x) em $18 \mathrm{ml}$ de água destilada, totalizando $20 \mathrm{ml}$. Imersão das lâminas na solução e aquecimento em banho-maria por 20 min, mantendo a temperatura entre $92^{\circ} \mathrm{C}$ e $95^{\circ} \mathrm{C}$, seguida de lavagem em água destilada.

6. Lavagem em solução salina (PBS 1x - Phosphate Buffered Saline) duas vezes.

7. Bloqueio da peroxidase endógena (Peroxidase Block, DakoCytomation, Code K 4008, Carpintaria, EUA). Aplicação de uma gota proporcional sobre cada corte e aguardar 5 minutos.

8. Lavagem em PBS, duas vezes.

9. Anticorpo primário, concentração de 1:500, diluição específica para Fator VIII (1 $\mu$ l do anticorpo diluído em $500 \mu$ l (10 gotas) de diluente, durante 30 minutos. 
10. Lavagem em PBS, três vezes.

11. Anticorpo secundário e sistema de detecção (Labelled Polymer- HRP, DakoCytomation, anti-rabbit, Code K4008, Carpintaria, EUA). Aplicação de uma gota da solução sobre os cortes mantendo-a por 30 minutos.

12. Lavagem em PBS, três vezes.

13. Revelação com o cromógeno AEC (AEC + substrate chromogen, DakoCytomation, ref. K 4008, Carpintaria, EUA). Aplicação de uma gota da solução em cada corte, controlando a coloração no microscópio de transmissão de luz.

14. Lavagem em água destilada, três vezes, durante 5 minutos cada.

15. Realização da contra-coloração com Hematoxilina por 3 segundos.

16. Lavagem em água corrente até remover o excesso da coloração.

17. Lavagem em água destilada.

18. Desidratação por meio de trocas graduais de álcoois $70 \%, 95 \%$ e $100 \%$ (2 minutos cada).

19. Imersão em xilol (três trocas de 3 minutos cada).

20. Montagem da lâmina.

Como já é característica, a imagem produzida pela técnica imuno-histoquímica com a utilização do Fator VIII- Von Willebrand anticorpo específico para a marcação de células endoteliais e vasos sangüíneos - descartou-se a necessidade da realização de um controle positivo e negativo.

\subsubsection{Teste do Tunel ( Tunel Assay - In situ cell death detection kit- AP)}

O teste do Tunel (TdT (-Terminal deoxynucleotidly transferase)- mediated X-dUTP nick end labeling) é um teste específico para detecção de células apoptóticas ou em processo de apoptose celular. A marcação para células apoptóticas (coloração azul escuro - BCIP/NBT) com a utilização do teste do Tunel, seguiu as recomendações do fabricante (Roche) ${ }^{55}$ e o seguinte protocolo: 


\section{Desparafinização \& Reidratação}

1. Pré-aquecimento das lâminas por 30 minutos à temperatura de $60^{\circ} \mathrm{C}$.

2. Desparafinização em xilol (três trocas de 3 minutos cada).

3. Reidratação por meio de trocas graduais de álcoois $100 \%, 95 \%$ e $70 \%$ (2 minutos cada).

4. Lavagem em água destilada durante 5 minutos.

\section{Tratamento das lâminas}

1. Incubação das lâminas por 15 minutos à temperatura de $37^{\circ} \mathrm{C} \mathrm{com} 5 \mathrm{ml}$ de Proteinase $\mathrm{K}$ working solution $(15 \mu \mathrm{g} / \mathrm{ml}$ em $10 \mathrm{mM}$ Tris / $\mathrm{HCL}$ (Fisher Biotech, Fair Lawn, New Jersey), pH 7.4. Aplicação de somente uma gota sobre cada corte.

2. Lavagem em solução de PBS 1x (Phosphate Buffered Saline), por duas vezes.

\section{Identificação das quebras do molde de DNA com fluorescina -dUTP (Labeling DNA strand breaks with fluorescein-dUTP)}

1. Secagem da área ao redor dos cortes

2. Adição de $50 \mu \mathrm{l}$ da mistura da reação do Tunel (Tunel reaction mixture) em cada corte. Esta mistura deve ser preparada imediatamente antes do seu uso, sendo mantida em gelo até o momento de sua utilização.

3. Aquecimento das lâminas por 60 minutos à temperatura de $37^{\circ} \mathrm{C}$ em atmosfera umidificada escurecida.

4. Lavagem em solução de PBS 1x (Phosphate Buffered Saline), por três vezes.

\section{Conversão de sinal com o conjugado anti-fluorescina- AP}

\section{(Signal Conversion with Anti-fluorescein-AP conjugate)}

1. Secagem da área ao redor dos cortes

2. Adição de $50 \mu \mathrm{l}$ da solução Convert- AP sobre os cortes.

3. Aquecimento das lâminas por 30 minutos à temperatura de $37^{\circ} \mathrm{C} \mathrm{em}$ câmara úmida 
4. Lavagem em solução de PBS 1x (Phosphate Buffered Saline), por três vezes.

\section{Solução de Substrato Fosfatase Alcalina}

\section{(Alkaline Phosphatase Substrate Solution)}

1. Adição de $50 \mu \mathrm{l}$ da solução de substrato (BCIP/ NBT - Vector Laboratories, Burlingame, CA, USA; Cat. No.SK- 5100) sobre os cortes.

2. Aquecimento das lâminas por 5 minutos à temperatura de 15 a $25^{\circ} \mathrm{C} \mathrm{em}$ ambiente escurecido.

3. Lavagem em solução de PBS 1x (Phosphate Buffered Saline), por três vezes.

\section{Montagem da lâmina}

As lâminas foram montadas seguindo a rotina do Laboratório de histologia da Universidade de Michigan. Confeccionou-se uma lâmina como controle negativo, no qual a mistura do Tunel não foi adicionada.

\subsection{ESTUDO IN VIVO}

Para a realização deste estudo foram utilizados seis camundongos fêmeas (CB.17. SCID), pesando, em média, 18 a 25 gramas com 10 semanas de vida. Esses animais foram obtidos do Laboratório do Charles River (Cambridge, MA), após a aprovação da Comissão de ética da Universidade de Odontologia de Michigan para pesquisas envolvendo animais (projeto UCUCA 8754). Os animais foram mantidos em gaiolas identificadas com o nome do pesquisador principal, nome do fornecedor, tipo do camundongo, idade do animal, telefone de contato do pesquisador, grupo e tempo experimental. Durante todo o período da pesquisa, as gaiolas foram limpas diariamente e os animais foram alimentados antes e durante o experimento, com exceção das primeiras doze horas pré e pós-operatórias, com água à vontade. Toda a manutenção, bem como cuidados pós-operatórios e medicações necessárias foram realizadas pelo grupo de veterinários da 
Universidade de Michigan responsáveis pelo acompanhamento do animal concomitantemente com o pesquisador.

\subsubsection{Intervenção cirúrgica}

Previamente à intervenção cirúrgica dos animais, o processo de preparação das fatias dentárias foi realizado seguindo o mesmo protocolo utilizado e já descrito aqui para o desenvolvimento do estudo in vitro. Foram utilizados terceiros molares hígidos, tanto superiores como inferiores, e premolares hígidos extraídos por razões ortodônticas.

Cada fatia de dente foi mantida em reservatórios individuais com capacidade para 12 espécimes (BD Falcon, BD Biosciences), contendo $1 \mathrm{ml}$ de meio de cultura celular preparado para as fatias dentárias DMEM (Dulbecco Eagle Modificado) com soro bovino fetal a $20 \%$, até o período de implantação.

Os camundongos imunodeprimidos (SCID) foram anestesiados por via intraperitonial com uma associação de cloridrato de ketamina (Ketaset, 100.0 mg/ml - solução; Fort Dodge Animal Health, lowa) e cloridrato de xilazina (Anasedan, 20.mg/ml; Lloyd Laboratories Shenandoa, lowa). Foi misturado 150ul de xilazina com 850ul de ketamina, utilizando-se a dosagem de $1 \mathrm{ul} / \mathrm{gr}$ da solução. Ambas as substâncias controladas foram fornecidas pela ULAM (Unit for Laboratory Animal Medicine) departamento da Universidade de Michigan. A anestesia foi realizada com o auxílio de uma seringa descartável para insulina (Figura 3).

Em seguida, os animais foram depilados na região dorsal com a utilização de um aparelho elétrico (Wahl Clipper Corporation, Model= CBTO, USA). (Figura 4). 


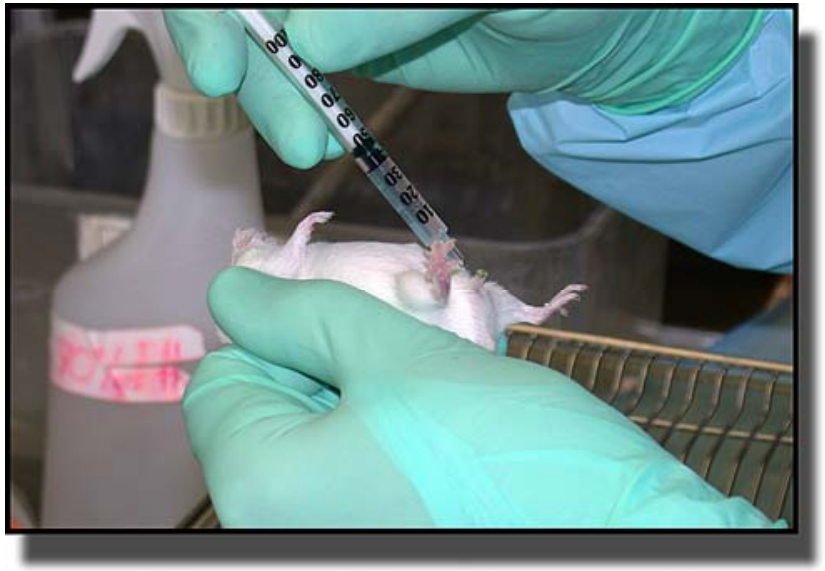

Figura 3. - Anestesia

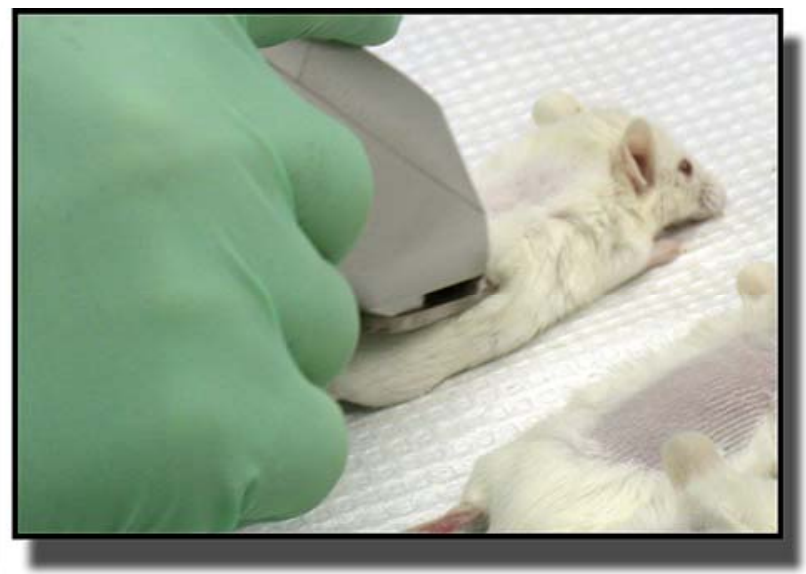

Figura 4. - Depilação

Após a depilação, efetuou-se anti-sepsia da região dorsal de cada camundongo com uma gaze estéril preparada com solução de etanol 70\% (Fisher Scientific, Model Fisherbrand Medium Sterile Alcohol Prep Pad). Em seguida, realizou-se uma incisão linear $(1 \mathrm{~cm})$, com auxílio de um bisturi e uma lâmina número 12 (Feather Safety Razor Co LTD, Medical Division Japan, Model 22). Posteriormente à divulsão do tecido, quatro fatias de dente humano com $1.5 \mathrm{~mm}$ de espessura foram implantadas subcutaneamente na região dorsal de cada camundongo (Figura 5). 


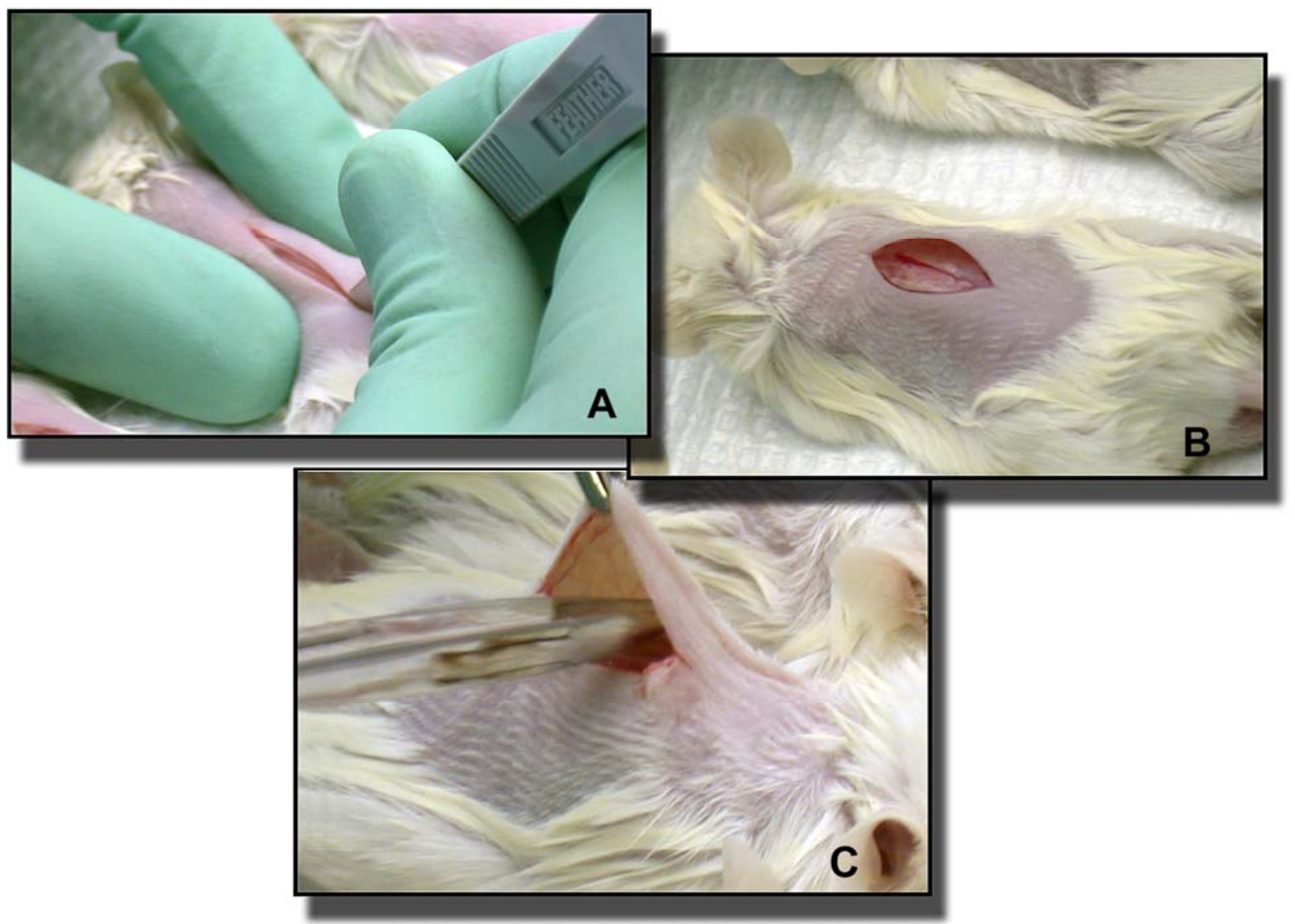

Figura 5 - (A) Incisão, (B) divulsão e (C) implantação das fatias dentárias.

Realizou-se, então, a aproximação dos tecidos incisionados com auxílio de uma pinça cirúrgica e a sutura com cola adesiva utilizando o Vetbond (3M Animal care Products, USA) cobrindo toda a extensão da incisão (Figura 6). Decorrido o período experimental de 7 dias, foi feita a eutanasia dos animais por deslocamento cervical. Em seguida, realizou-se o rebatimento do tecido do dorso do animal com a finalidade de exposição e remoção das fatias dentárias (Figura 7). As mesmas foram imediatamente imersas individualmente em tubos de $15 \mathrm{~mm}$ (Denville Scientific INC. Nwe Jersey, USA), contendo solução de formalina a 10\% (Fisher Scientific) (Figura 8). 



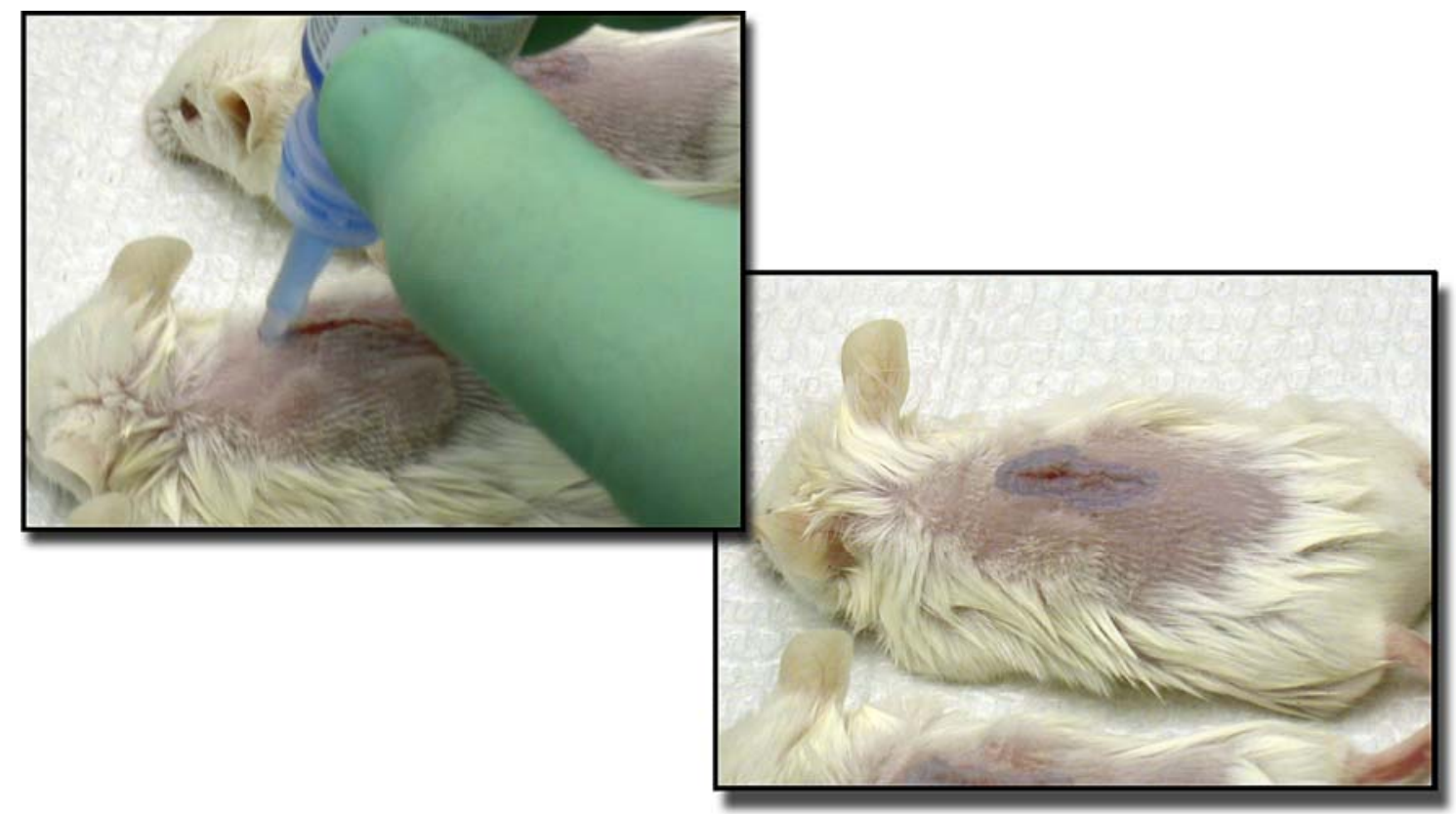

Figura 6 - Sutura química com VET BOND

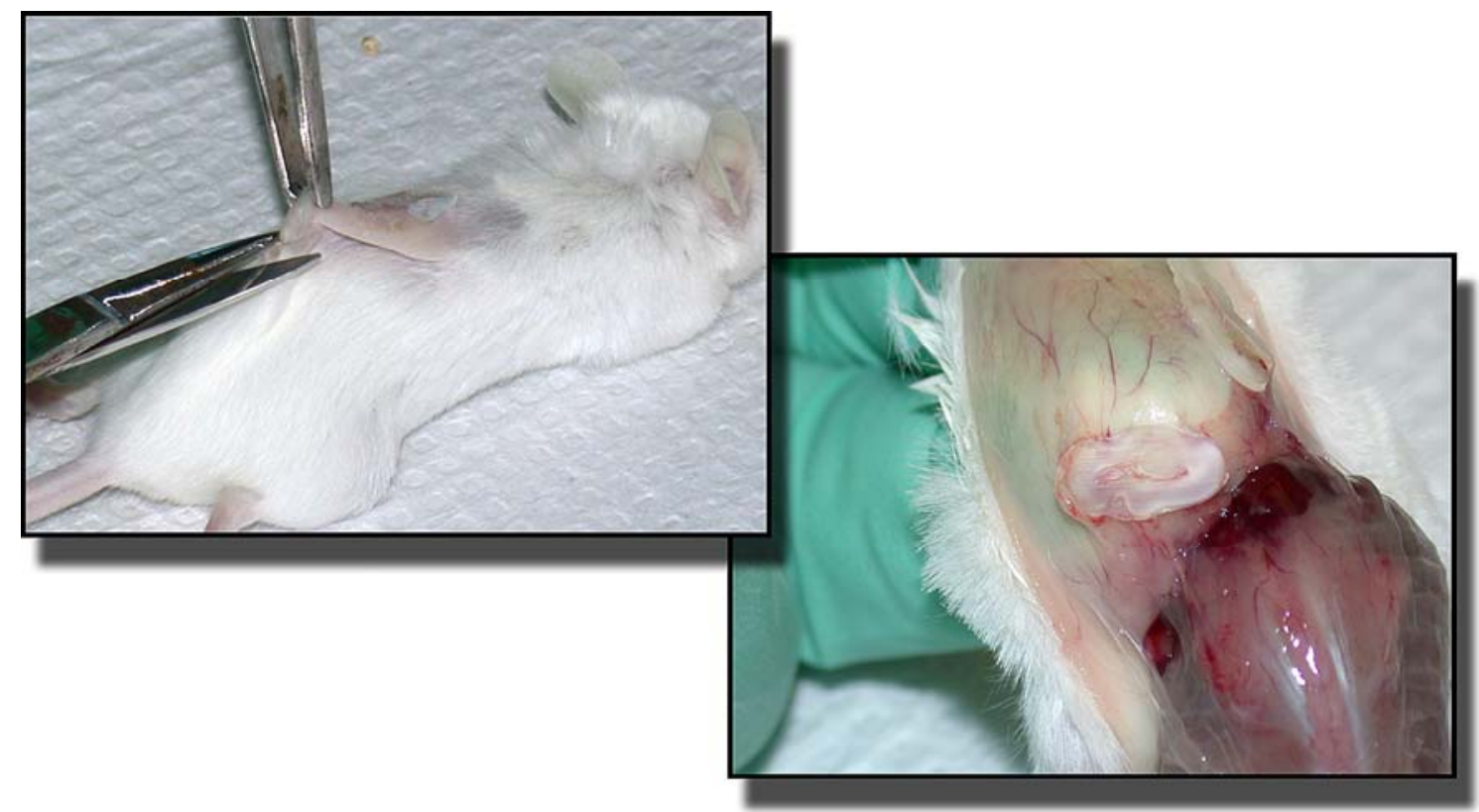

Figura 7 - Remoção das fatias dentárias após 7 dias da implantação 


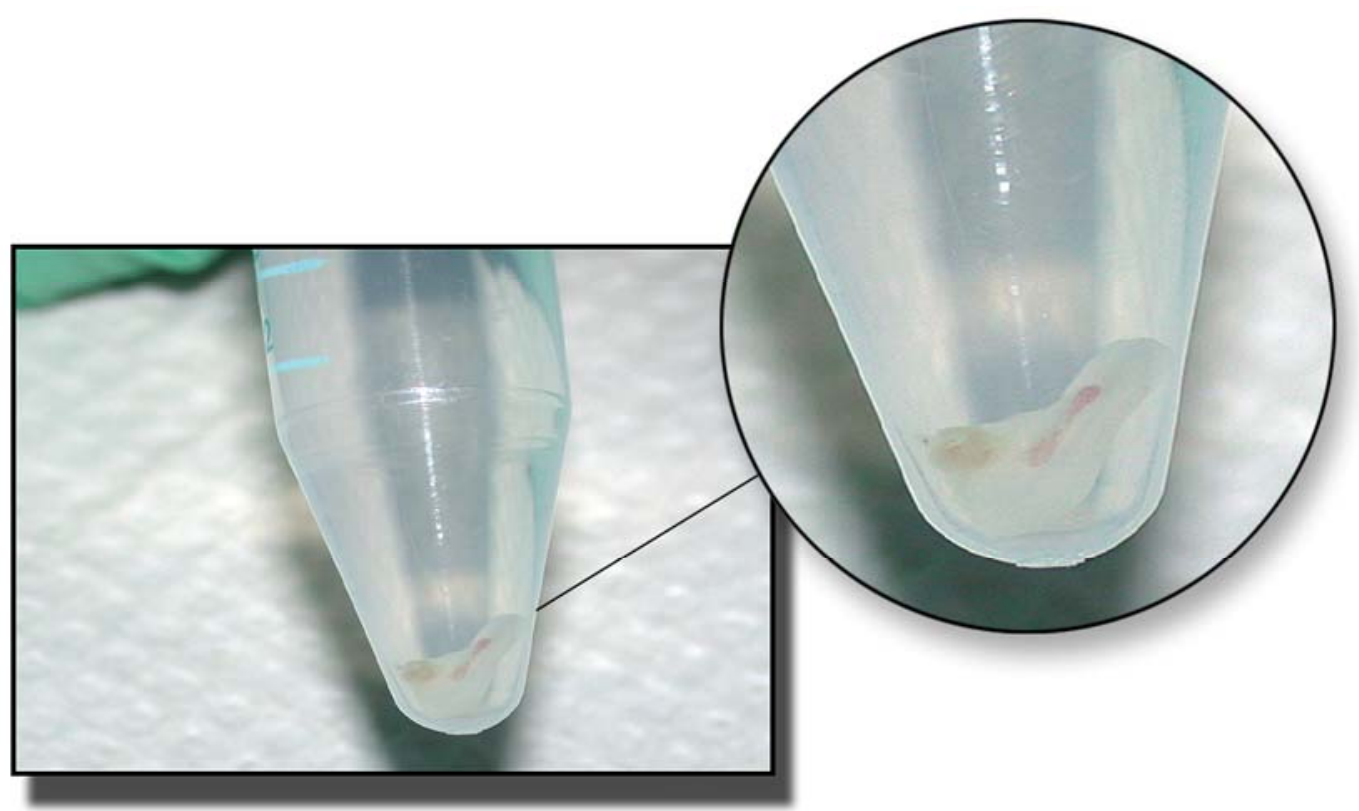

Figura 8 - Fatia dentária imersa em formalina a 10\%

O processamento laboratorial seguiu o protocolo utilizado para o estudo in vitro já descrito anteriormente. Foram realizadas as mesmas avaliações pela análise microscópica, imuno-histoquímica e teste do Tunel com o intuito de verificar a vitalidade, vascularização e apoptose celular do tecido pulpar presente na fatia dentária.

Deve-se ressaltar que a intervenção cirúrgica em camundongos imunodeprimidos (SCID mice) seguiu as recomendações do guia de cuidados e uso de animais de laboratório da Universidade de Michigan. Os procedimentos cirúrgicos foram realizados no interior de uma capela de fluxo laminar para evitar contaminação, pois, se isso ocorresse, poderia levar à perda do animal. Todos as barreiras de proteção contra patógenos foram também utilizadas.

\section{Avaliação dos resultados}

As imagens visualizadas em $\mathrm{HE}$, imuno-histoquímica e teste do Tunel foram observadas e capturadas para análise com o auxílio do microscópio Nikon Scope Eclipse E $8000 \circledast$ (Nikon, Melville, EUA) acoplado a 
um computador marca DELL® (Dell Inc., Round Rock, USA), através do programa Image Pro-Plus 5.1® (Media Cybernertics, Silver Spring, USA), para ambos estudos in vitro e in vivo.

\section{Coloração de HE}

A vitalidade do tecido pulpar foi observada por meio da análise microscópica com auxílio do microscópio de transmissão de luz tanto para o estudo in vitro como para o estudo in vivo. Considerou-se como critério de avaliação a observação de:

$\leftrightarrow$ tecido pulpar com presença de camada odontoblástica, com vasos sangüíneos, fibroblastos e outros tipos celulares na porção central da polpa, áreas de fibras colágenas, mas sem evidência de reação inflamatória, porém com algumas áreas de degeneração celular.

\section{Técnica Imuno-histoquímica}

A observação da marcação (cor vermelha) realizada pela técnica de imuno-histoquímica para Fator VIII, específico para células endoteliais, foi quantificada pela contagem do número de vasos sangüíneos marcados (estudo in vitro). Padronizou-se esta contagem com a magnificação de 200x com o auxílio do microscópio de transmissão de luz. Oito cortes (fatias dentárias) de cada grupo (controle / VEGF) foram avaliados individualmente em 3 campos de observação (região superior, mediana e inferior), totalizando 24 áreas de avaliação em cada grupo. Os valores obtidos foram submetidos à análise estatística.

\section{Teste do Tunel}

Oito cortes (fatias dentárias) de cada grupo (controle / VEGF) foram avaliados individualmente em 3 campos de observação (região superior, mediana e inferior), totalizando 24 amostras de cada grupo (estudo in vitro). O número de células apoptóticas foi visualizado pela coloração azulescuro (BCIP/ NBT) com o auxílio do microscópio de transmissão de luz, utilizando a magnificação de 200x. Os valores obtidos foram submetidos à análise estatística. 
In vivo

A avaliação subjetiva qualitativa seguiu os seguintes critérios:

$\stackrel{\leftrightarrow}{\rightarrow}$ Presença de vitalidade do tecido pulpar, analisado por meio da coloração de HE.

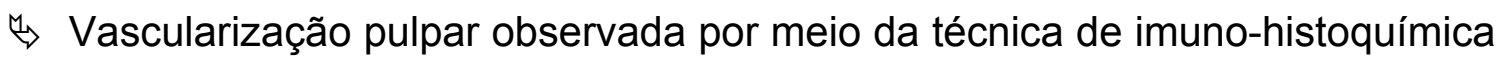
para Fator VIII- von Willebrand específico para células endoteliais.

$\stackrel{\leftrightarrow}{\wedge}$ Observação do número de células apoptóticas por meio do teste do Tunel.

\subsubsection{Considerações éticas}

O Projeto de pesquisa foi aprovado pelo comitê de ética da Universidade de Odontologia de Michigan, tanto para pesquisas envolvendo seres humanos= projeto IRB HO3-00001606-I, bem como para animais = projeto UCUCA 8754.

\subsubsection{Análise Estatística}

Os dados obtidos foram organizados em tabelas e empregados para a realização da análise estatística. Para a análise dos resultados obtidos com a técnica da imuno-histoquímica, para o estudo in vitro, utilizou-se o teste de Mann-Whitney Rank Sum com o auxílio do software estatístico SIGMASTAT 2.0 (SPSS,Chicago, IL, USA), com o grau de significância de $5 \%$. Já para o teste do Tunel, realizou-se a análise estatística utilizando o t-test com o grau de significância de 5\%, empregando-se o mesmo programa já mencionado.

Não foi feita estatística para o estudo in vivo, uma vez que os resultados foram analisados de forma qualitativa. 
5 RESULTADOS 



\section{RESULTADOS}

Para o desenvolvimento do modelo de angiogênese pulpar humana em camundongos imunodeprimidos (SCID mouse model of human pulp angiogenesis), usado no estudo do processo de revascularização da polpa dental, realizou-se primeiramente um estudo in vitro envolvendo a utilização de modelos de cultura, usando fatias de dente para o estudo da polpa dental. As fatias dentárias humanas foram mantidas in vitro por 7 dias na ausência (grupo controle) e presença de VEGF (grupo experimental). Vitalidade pulpar e vascularização das 24 amostras foram examinadas microscopicamente, seguidas da técnica de imuno-histoquímica. $\mathrm{O}$ número de células apoptóticas foi avaliado através da utilização do teste do Tunel.

Na Tabela 1 estão os dados obtidos in vitro com a técnica de imuno-histoquímica e teste do Tunel para os grupos controle e experimental (VEGF).

$\mathrm{Na}$ figura 9 observa-se a representação gráfica das médias do número de vasos sangüíneos observados nos cortes na marcação imunohistoquímica em função do uso ou não do VEGF no estudo in vitro.

$\mathrm{Na}$ figura 10 observa-se a representação gráfica das médias do número de células apoptóticas observadas nos cortes na marcação com o teste em Tunel, em função do uso ou não do VEGF no estudo in vitro.

Os cortes em HE mostraram tecido pulpar vital com camada de odontoblastos apresentando características normais em ambos os grupos (com e sem VEGF) (Figura 11 e 12).

As figuras 13 e 14 mostram imunomarcação de células endoteliais, vasos sangüíneos, realizada com o anticorpo primário - Fator de von Willebrand (Fator VIII, Ab-1 Rabbit Pab). A análise estatística utilizando o teste de Mann-Whitney Rank Sum com o auxílio do programa SIGMASTAT 2.0 (SPSS, Chicago, IL, USA) mostrou que o tecido pulpar no grupo experimental (50ng/ml VEGF) apresentou uma diferença estatisticamente significante $(p<0.05)$ em relação ao número de vasos sangüíneos $(67.8$ t/-, $26.7 \mathrm{dp})$, 
comparado com o grupo controle - sem VEGF (46.2 +/-, 18.9 dp). O nível de significância foi $p<0.05$.

O teste do Tunel (In situ cell death detection kit, AP) utilizado para a verificação do número de células apoptóticas no tecido pulpar, tanto para o grupo controle - sem VEGF, como para o grupo experimental $50 \mathrm{ng} / \mathrm{ml}$ VEGF, revelou pela análise estatística que não houve diferença estatística significante entre os grupos sem VEGF (controle) e com VEGF (experimental). Nas figuras 15 e 16 estão as marcações para células apoptóticas pelo teste do Tunel (Tunel assay), para os grupos controles e experimentais. A figura 17 representa o controle negativo da reação.

A figura 18 mostra o resultado do RT-PCR, realizado para avaliar a expressão do receptor VEGFR-2 mRNA nas células pulpares indiferenciadas de camundongo, OD-2, células tipo odontoblasto de camundongo - MDPC-23, macrófagos de camundongo e nas células endoteliais da microvasculatura da derme humana - HDMECs (Cell System Corp., Kirkland, WA). O gliceraldeído adenosina fosfato desidrogenase (GAPDH - 683 bp) foi usado como controle interno para a amplificação da PCR. As células HDMECs foram usadas como controle positivo da reação. $A$ expressão de VEGFR-2 mRNA foi observada nas células endoteliais da microvasculatura da derme humana - HDMECs, mas não nas outras 3 linhas celulares. Entretanto, RNAm para GAPDH foi detectado em todas as células avaliadas neste estudo (Figura 18).

A vitalidade pulpar, vascularização e apoptose celular no estudo in vivo foram examinadas pela microscopia óptica em coloração pelo $\mathrm{HE}$, seguida pela técnica imuno-histoquímica e pelo teste de Tunel assay. No momento da remoção das fatias dentárias implantadas, foi observado que o tecido pulpar se encontrava bastante vascularizado (Figura 19). O exame microscópico $(\mathrm{HE})$ revelou tecido pulpar com aparência normal com presença de camada de odontoblastos observados em todos os espécimes e com um significante número de células e vasos sangüíneos (Figura 20). A técnica de imuno-histoquímica foi realizada com a utilização de um anticorpo primário Fator de Von Willebrand (Fator - VIII). Observou-se um grande número de vasos sangúíneos e células endoteliais marcadas pelo fator VIII, sugerindo-se, desse modo, que o tecido pulpar humano manteve suas condições de 
viabilidade após os 7 dias de implantação (Figura 21). A presença de células apoptóticas foi confirmada pelo teste de Tunel, que detectou um pequeno número das mesmas no tecido pulpar (Figura 22).

Tabela 1 - Dados obtidos com o estudo in vitro pela técnica de imuno-histoquímica (número de vasos sangüíneos) e teste de Tunel (número de células apoptóticas) encontrados no grupo controle (sem VEGF) e no grupo experimental (50ng/ml VEGF).

\begin{tabular}{|c|c|c|c|c|c|}
\hline & \multicolumn{2}{|c|}{ Controle } & \multicolumn{2}{|c|}{ VEGF } & \multirow{2}{*}{ Estatística } \\
\hline & $(+/-)$ & $d p$ & $(+/-)$ & $\mathrm{dp}$ & \\
\hline $\begin{array}{l}\text { Vasos } \\
\text { Sangüíneos }\end{array}$ & 46.25 & 18.96 & 67.87 & 26.79 & $\begin{array}{c}\text { Mann- Whitney } \\
\mathrm{p}<0,001^{*}\end{array}$ \\
\hline $\begin{array}{l}\text { Células } \\
\text { Apoptóticas }\end{array}$ & 73.75 & 33.73 & 56.91 & 23.82 & teste "t" $p=0,052$ ns \\
\hline
\end{tabular}

ns - diferença estatisticamente não significante

* diferença estatisticamente significante

dp- desvio- padrão

+/- - média 


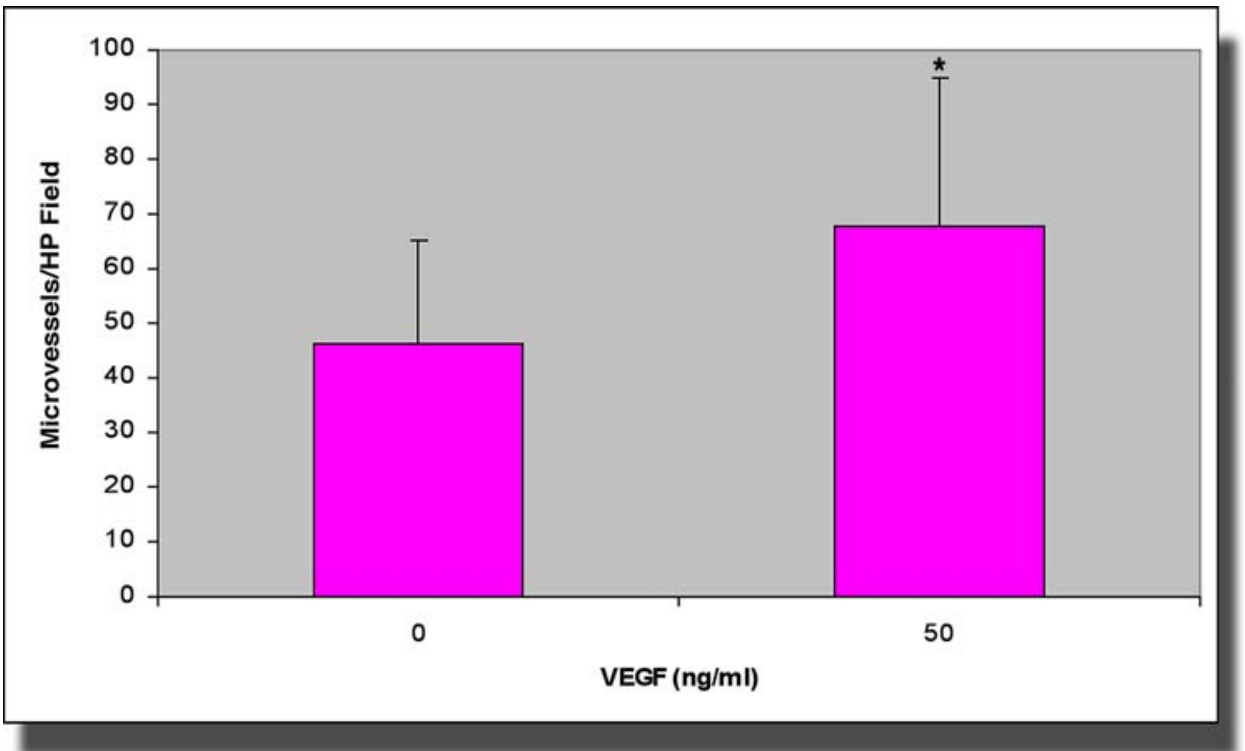

Figura 9 - Representação gráfica das médias dos números de vasos sangüíneos observados nos cortes pela marcação de imuno-histoquímica em função do usoou não do VEGF.

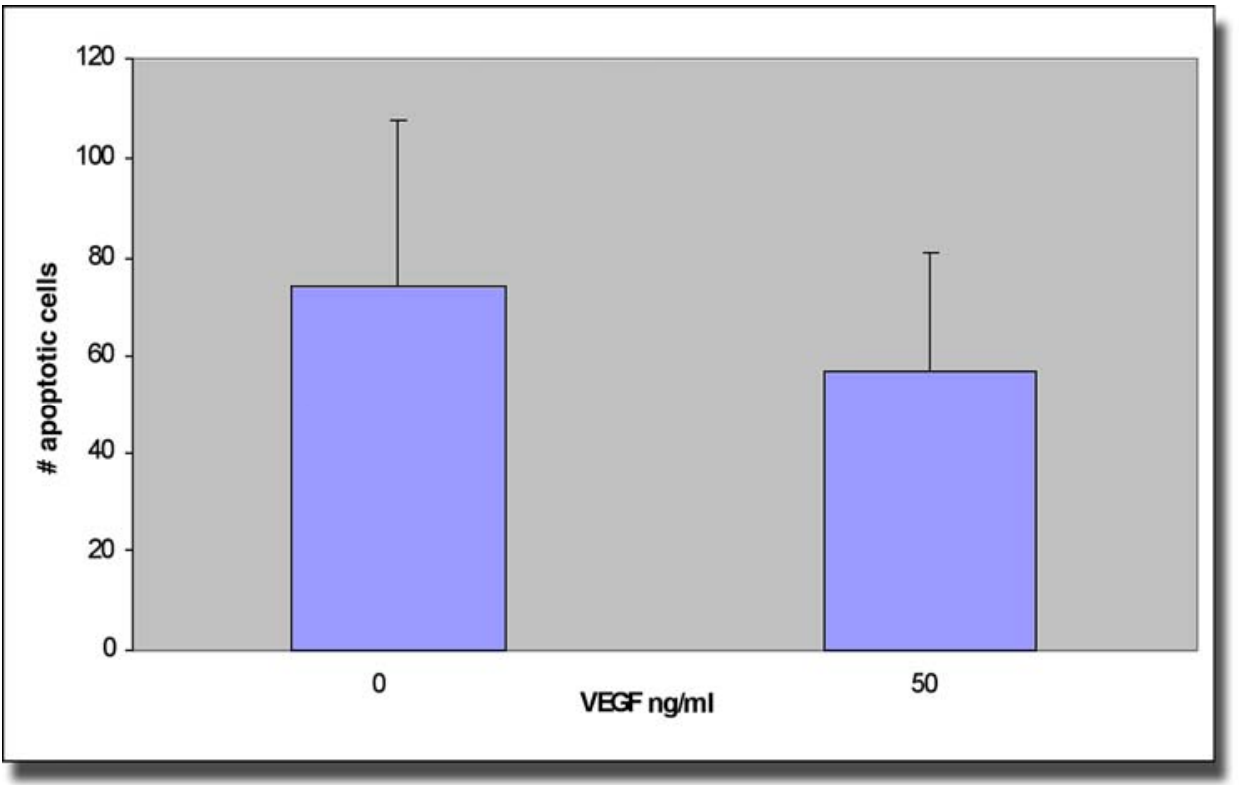

Figura 10 - Representação gráfica das médias dos números de células apoptóticas observadas nos cortes pela marcação com o teste de TUNEL em função do uso ou não do VEGF. 

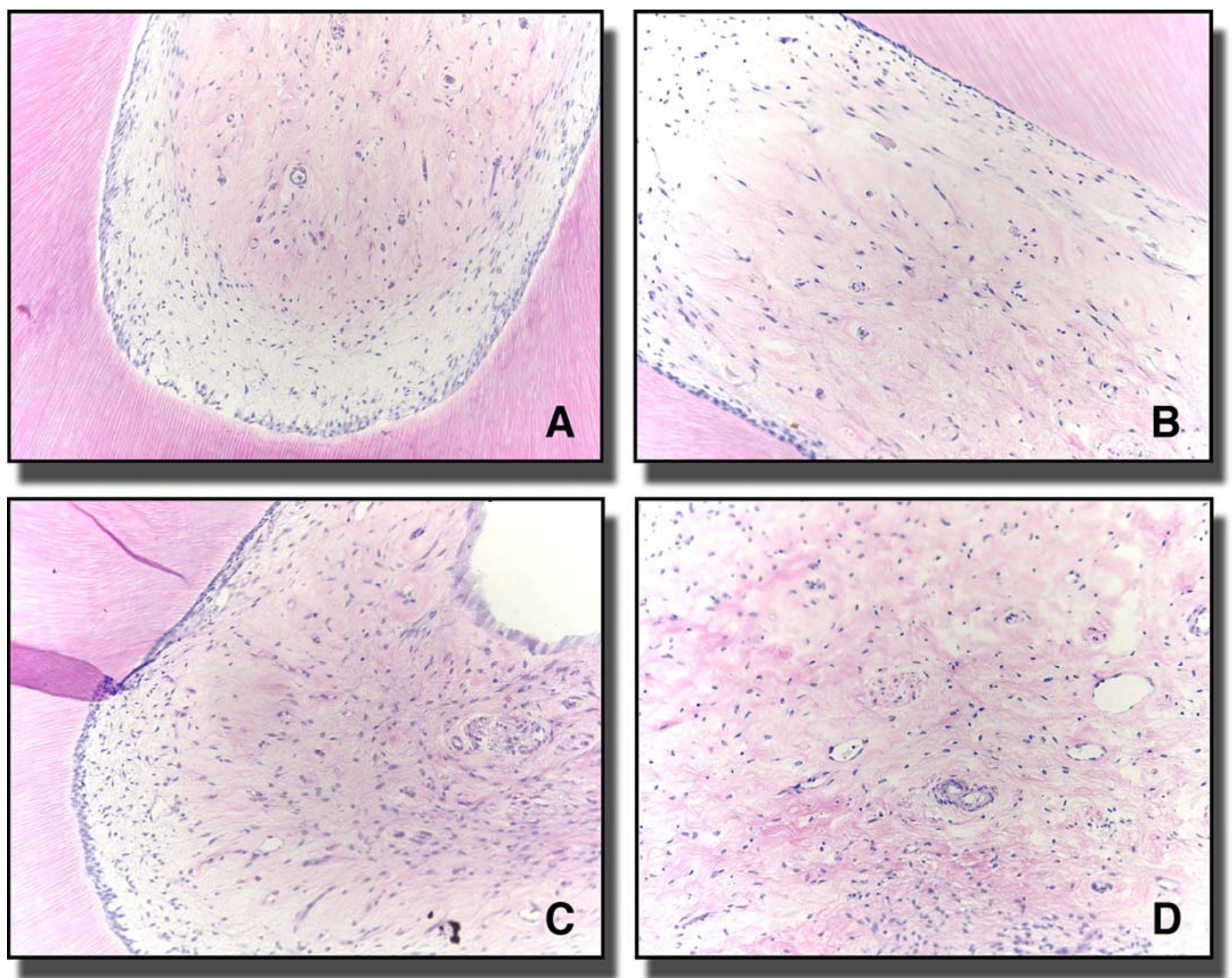

Figura 11 - Tecido pulpar e camada odontoblástica com aspecto de normalidade nos grupos controle (A e B) e VEGF 50ng/ml (C e D), magnificação de 200x, HE). 



Figura 12 - Tecido pulpar e camada odontoblástica com aspecto de normalidade nos grupos controle (A e B) e VEGF 50ng/ml (C e D), magnificação de 400x, (HE). 

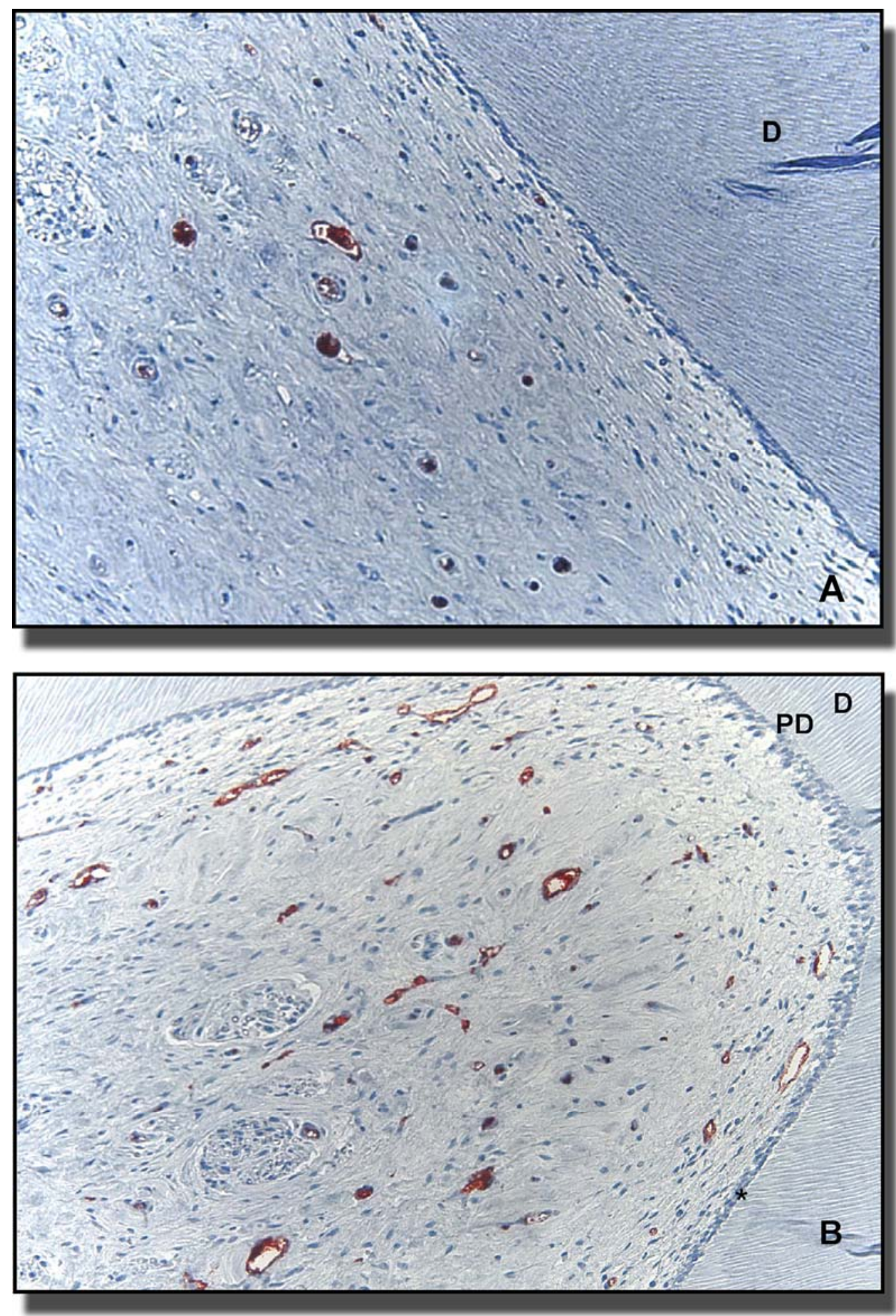

Figura 13 - Imunomarcação para células endoteliais e vasos sangüíneos (Fator VIII, vermelha (AEC). Controle (A) e VEGF 50ng/ml (B), magnificação de 200x. $D=$ dentina; $P D=$ pré-dentina; camada de odontoblasto * 

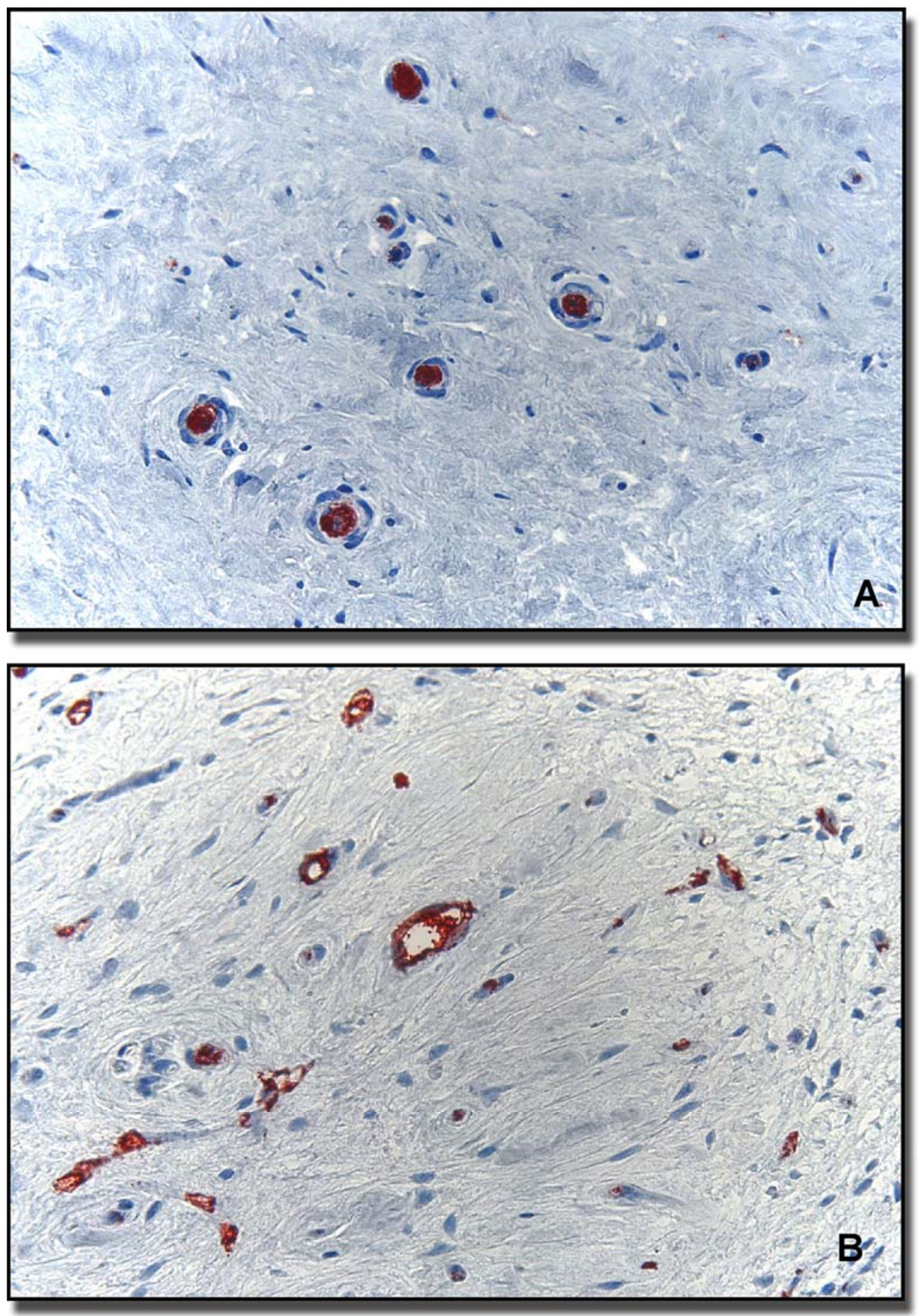

Figura 14 - Imunomarcação para células endoteliais e vasos sangüíneos (Fator VIII - vermelha -AEC). Controle (A) e VEGF 50ng/ml (B), magnificação de 400x. 



Figura 15 - Marcação para células apoptóticas (setas) pelo teste do Tunel (BCIP/NBT - azul escuro) para os grupos controle (A) e VEGF 50ng/ml (B), magnificação de 200x. 

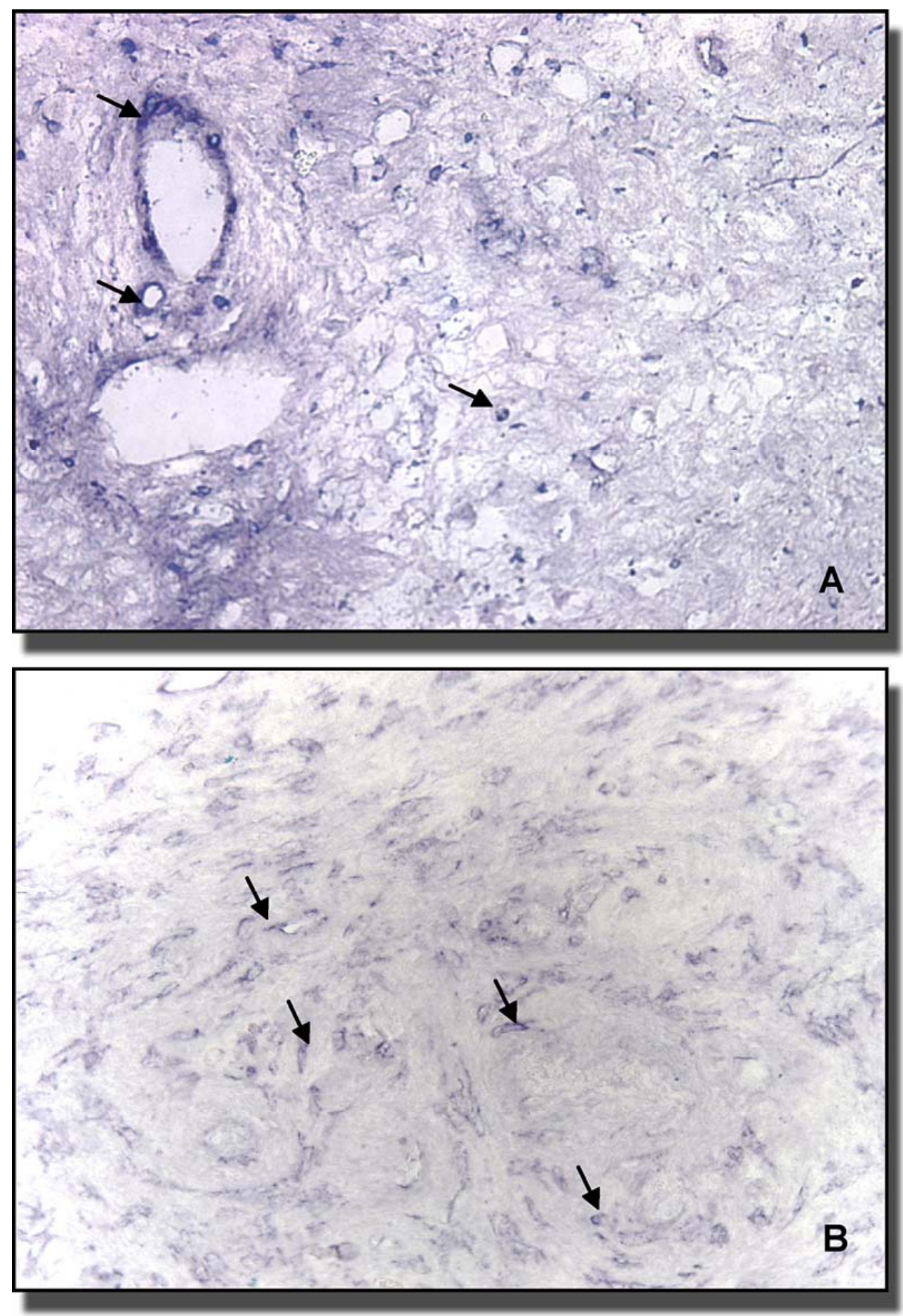

Figura 16. Marcação para células apoptóticas (setas) pelo teste do Tunel (BCIP/NBT azul escuro) para os grupos controle (A) e VEGF 50ng/ml (B), magnificação de 400x. 


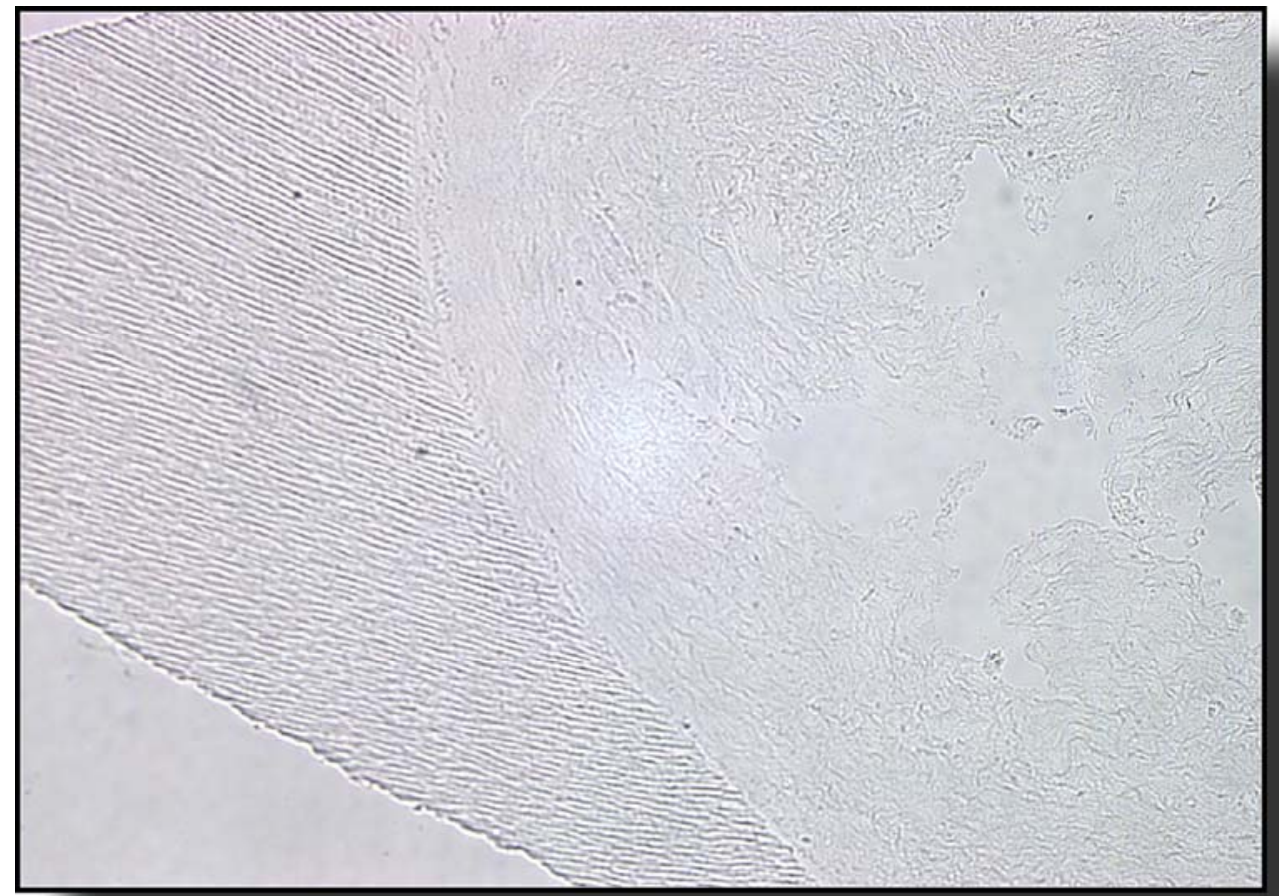

Figura 17 - Controle negativo para o teste de Tunel (BCIP/NBT - azul escuro magnificação de 200x. 

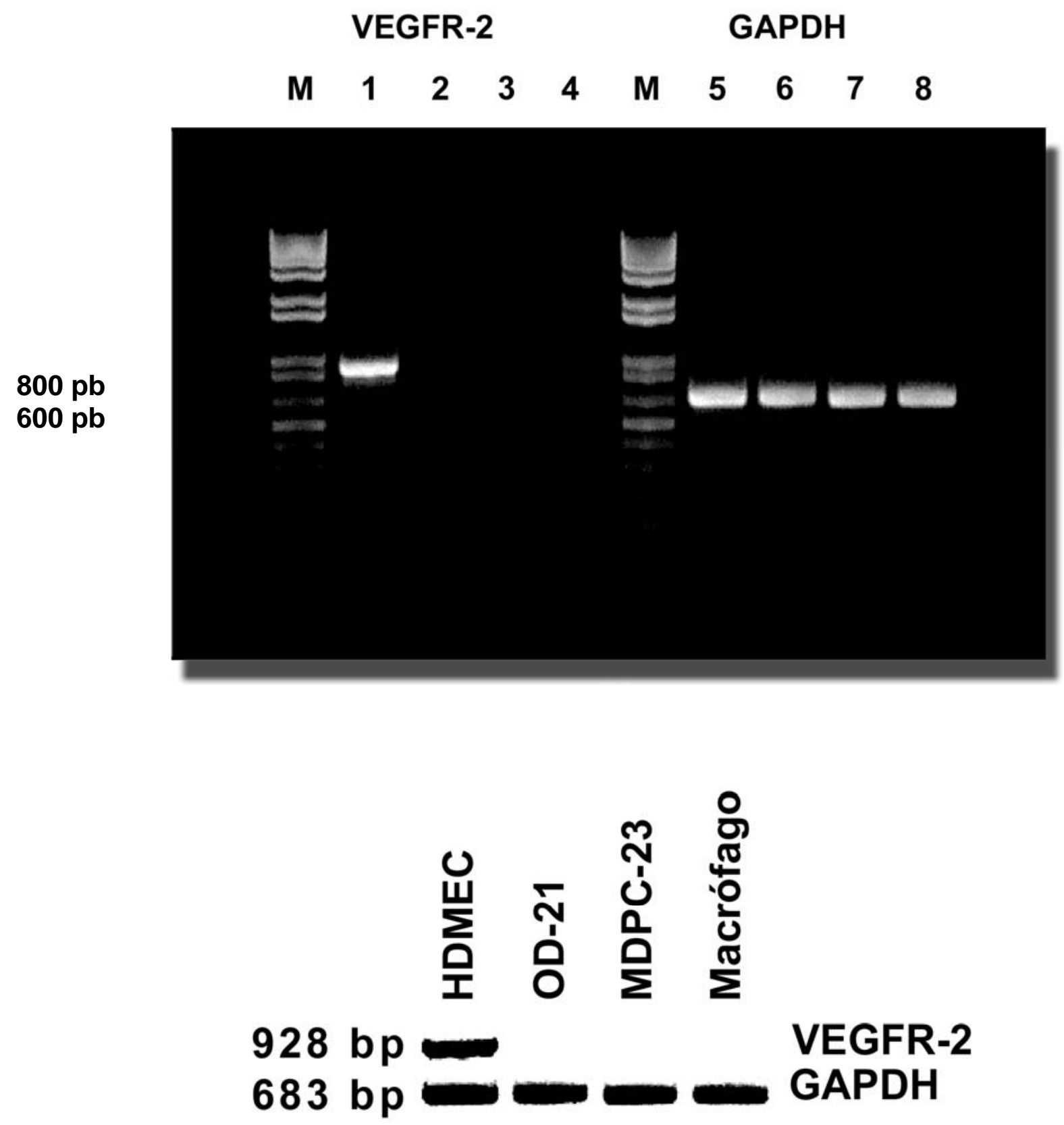

Figura 18 - Gel de agarose corado com brometo de etídeo para a detecção, por RT-PCR, da expressão do RNAm para VEGFR-2 (1, 2, 3 e 4) em células endoteliais- HDMEC (1), OD-21 (2), MDPC-23 (3) e macrófagos (4). Os cDNAs foram amplificados por PCR com primers específicos para VEGFR-2 (928 pb) e para GAPDH (683 pb), controle interno da reação. Controle positivo HDMEC (1,5); Coluna 1, RNAm para VEGFR-2 detectado nas células (HDMECs); Coluna 2,3 e 4 PCR de RNA total das células utilizando primers específicos para VEGFR-2; Coluna 5, 67 e 8 RNAm para GAPDH detectado nas células (HDMEC (5), OD-21 (6), MDPC-23 (7) e macrófagos (8). M, marcador de peso molecular de $1 \mathrm{~kb}$. 



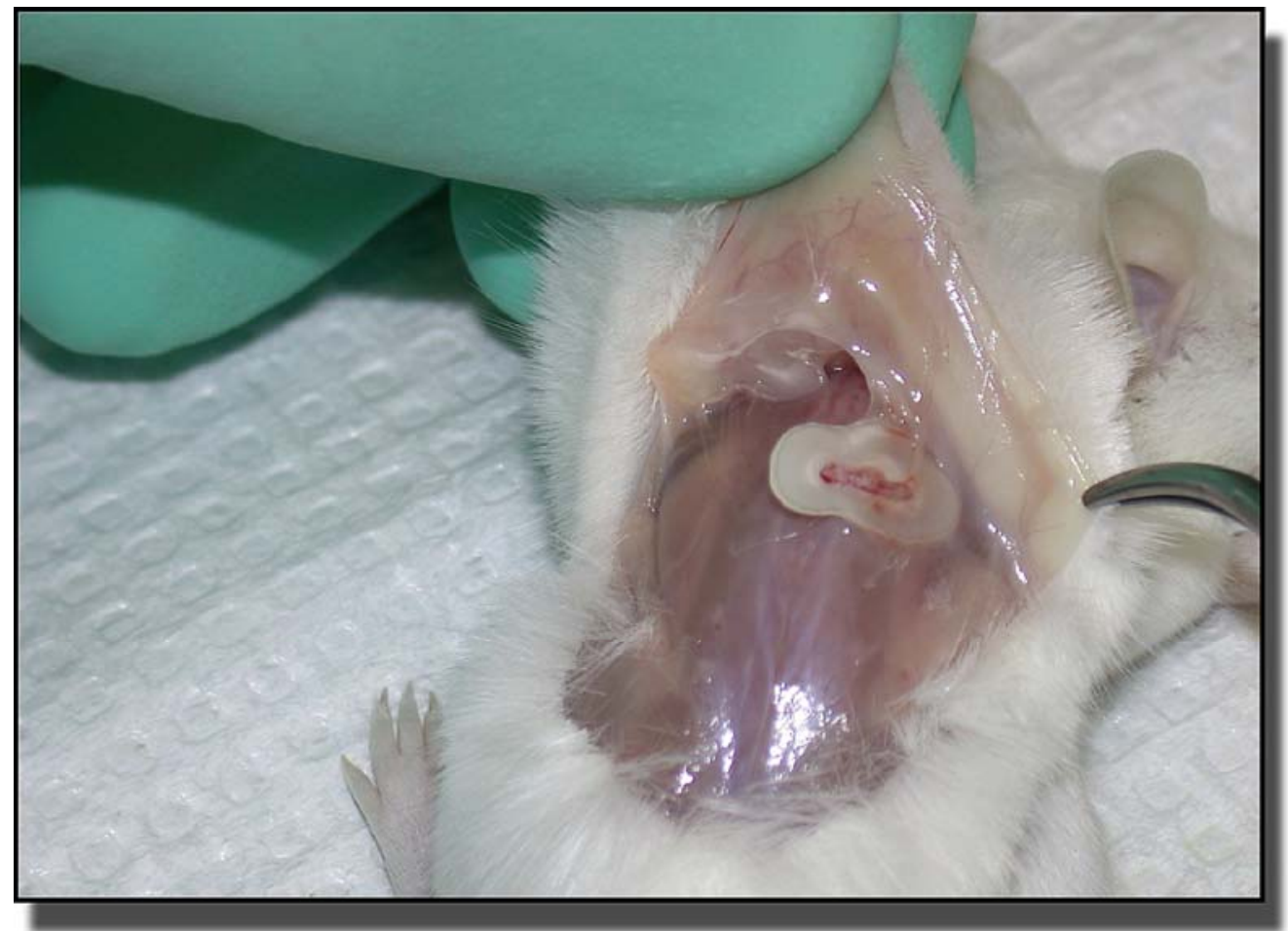

Figura 19 - Fatia dentária apresentando tecido pulpar vascularizado após 7 dias da implantação. 

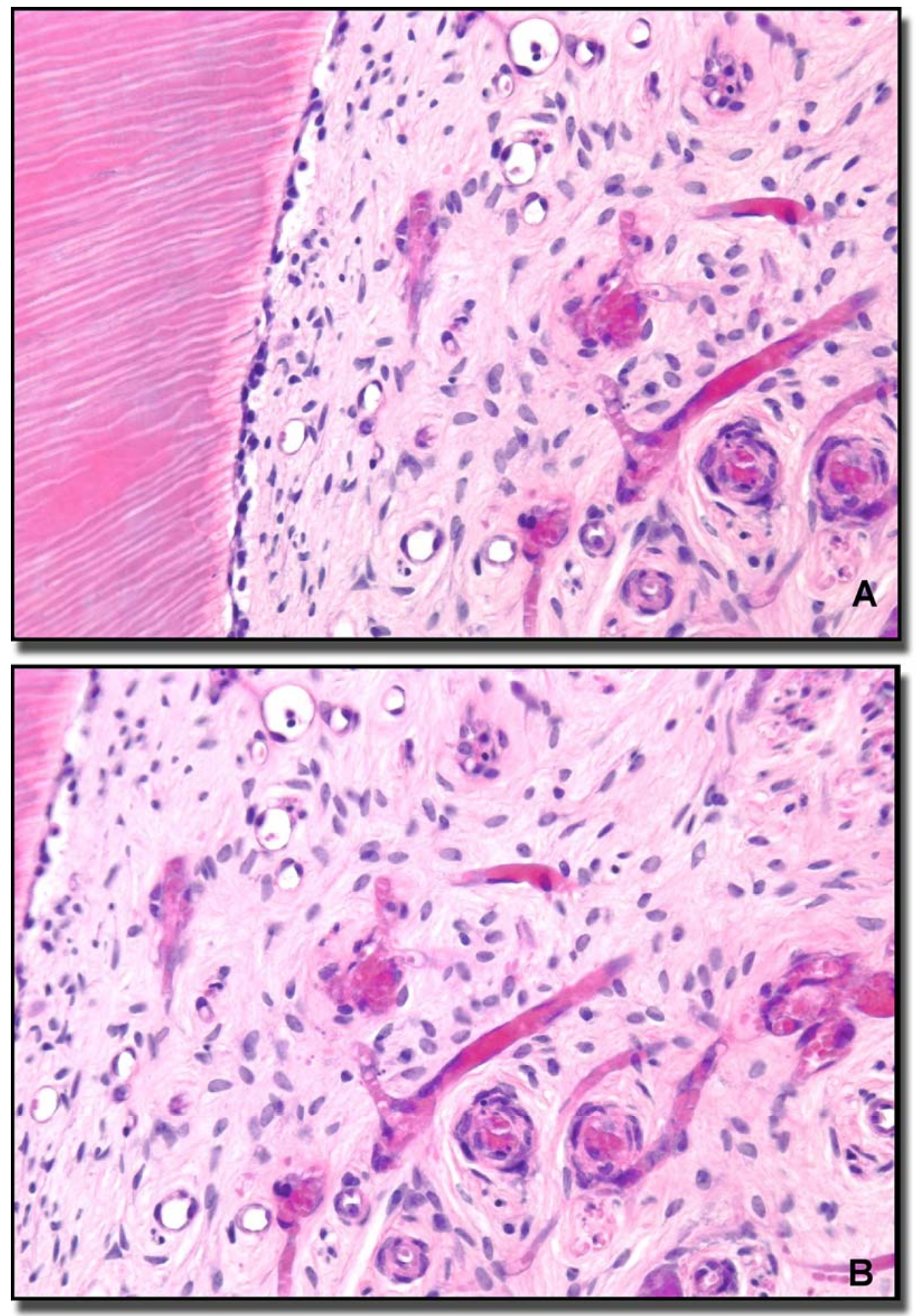

Figura 20 - Tecido pulpar com aspecto de normalidade, apresentando um significante número de células e vasos sangüíneos ( HE magnificação de 200x (A) e 400x (B). 


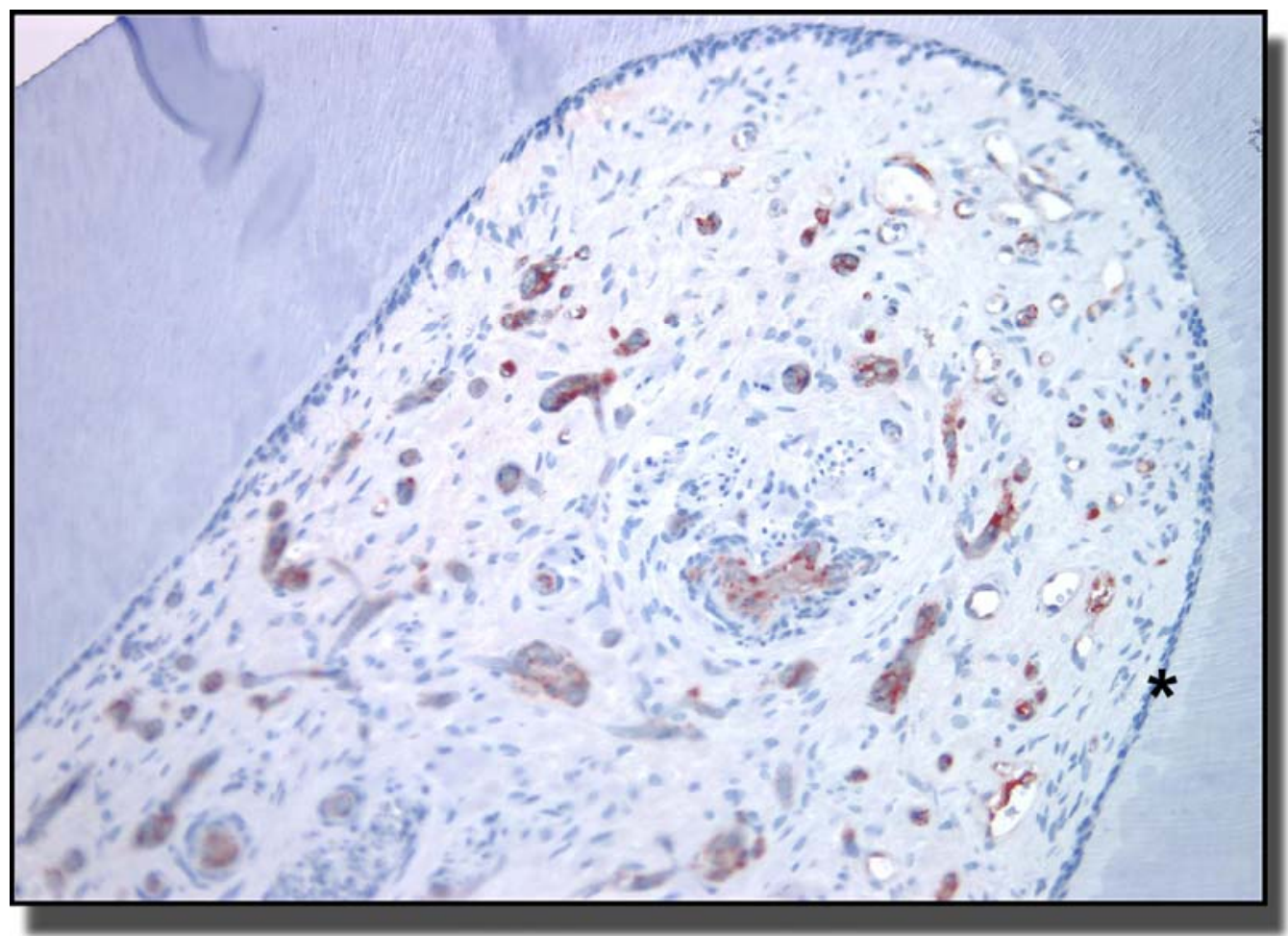

Figura 21 - Imunomarcação para vasos sangúíneos e células endoteliais (Fator VIII -vermelho AEC), confirmando a viabilidade do tecido pulpar após os 7 dias de implantação. Magnificação de 200x. Camada de odontoblasto íntegra*. 

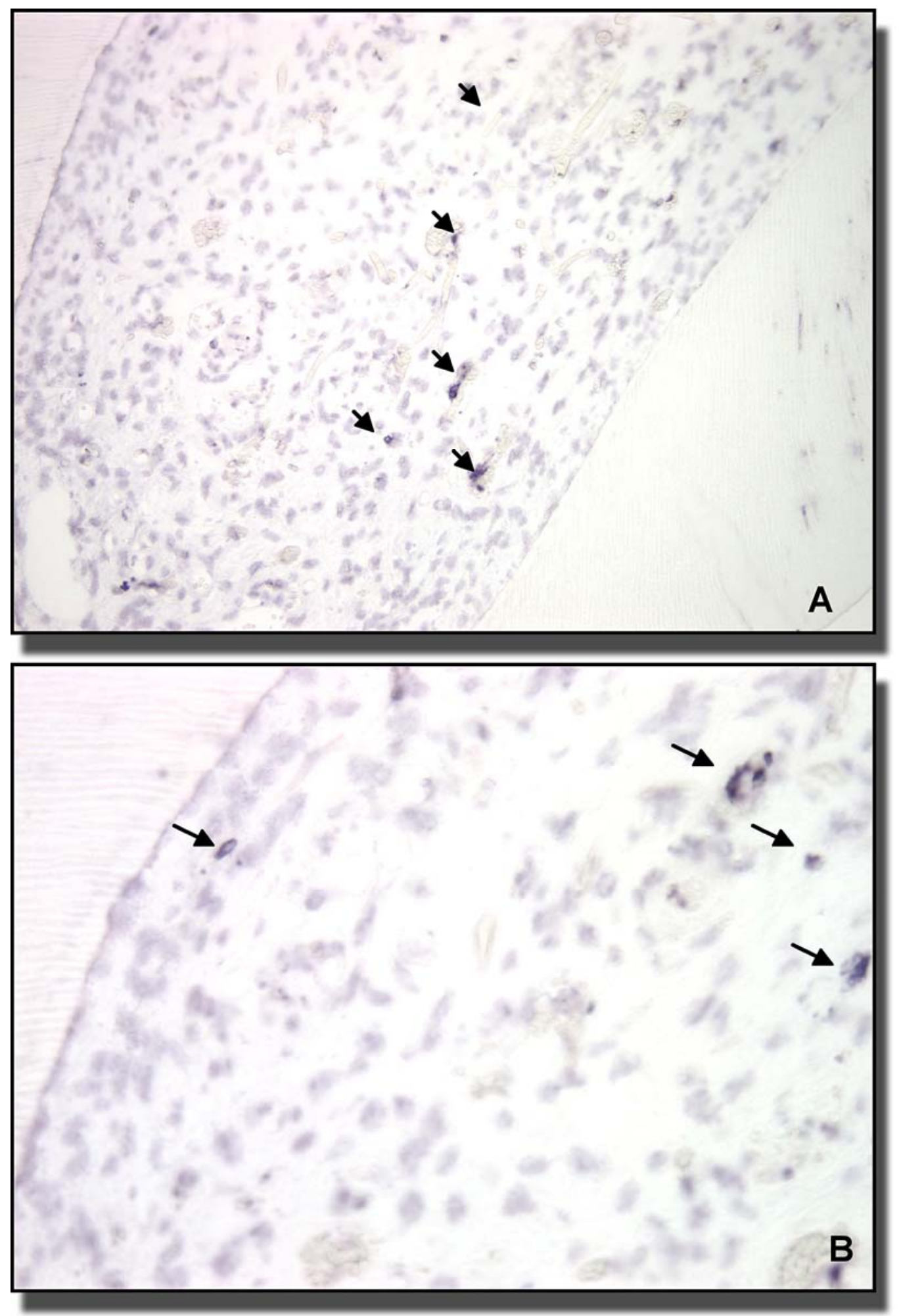

Figura 22 - Células apoptóticas (setas) no tecido pulpar. Teste de Tunel. Magnificação de 200x (A) e $400 x(B)$. 


\section{DISCUSSÃO}





\section{DISCUSSÃO}

\subsection{METODOLOGIA}

\subsubsection{Estudo in vitro - cultura das fatias dentárias}

Foi realizado previamente, com o intuito de se estabelecer a metodologia proposta nesta pesquisa, um trabalho piloto seguindo 0 protocolo do Dr. Antony Smith no que se refere à realização de todo procedimento in vitro envolvendo o corte das fatias dentárias, bem como sua cultura. Optimizou-se o protocolo dando a ele um caráter personalizado simplificando algumas etapas. Foram encontradas algumas dificuldades no que se refere ao procedimento dos cortes das fatias dentárias humanas, bem como na obtenção de uma amostra adequada, ou seja, dentes hígidos vitalizados de pacientes jovens.

A obtenção da amostra no primeiro momento se concentrava na aquisição de dentes pré-molares hígidos extraídos de pacientes jovens por razões ortodônticas. Normalmente, nestes casos, os pacientes se encontravam na faixa de 12 anos de idade. As dificuldades em conseguir-se pré-molares nos levaram a optar pelo uso de terceiros molares hígidos extraídos.

Uma das complicações foi encontrar, inicialmente, um material ideal que proporcionasse uma fixação adequada da amostra (dente) a um suporte de madeira (escolha feita pelo fato de se poder autoclavar a madeira previamente ao seu uso) o qual, posteriormente, seria colocado na máquina de corte para obtenção das fatias dentárias. Primeiramente, utilizouse o cianocrilato (super-bond). Foi possível obter algumas fatias dentárias, porém o tempo para fixação adequada passava de 5 minutos e, mesmo assim, na maioria das vezes, durante o corte do dente, o mesmo se soltava do suporte de madeira ocasionando sua queda no interior da capela de fluxo contínuo ou 
até mesmo no reservatório de PBS 1x (Cellgro- Mediatech, Inc. Herndon, VA), líquido que era utilizado para manutenção da refrigeração durante o corte do dente. Passou-se, então, a utilizar outros tipos de materiais adesivos sugeridos pelo Dr. Rex Rolland, porém sem sucesso. Utilizou-se, também, a silicona de adição, porém a mesma dificultou o corte da fatia dentária, principalmente no momento da sua remoção. Apesar de muitos profissionais utilizarem a cera pegajosa número 7 para adaptar o dente ao braço da máquina de corte Isomet, no nosso caso isso não foi possível uma vez que trabalhávamos no interior da capela de fluxo contínuo, sendo a amostra descontaminada para posterior realização dos cortes, pois a cera proporcionaria uma possibilidade de contaminação. Finalmente, foi testada a utilização da resina acrílica ativada quimicamente, a qual proporcionou uma rápida fixação do dente ao suporte de madeira e um ótimo desempenho durante o procedimento de corte e obtenção das fatias dentárias.

A espessura das fatias dentárias humanas constituiu-se, também, uma das preocupações, não pelo fato de se conseguir padronizar a espessura recomendada de 1,5 a $2 \mathrm{~mm}^{76,87,88,125}$, mas em obter uma espessura adequada que proporcionasse, após os procedimentos de fixação e desmineralização, condições favoráveis para o corte histológico. Esse foi o nosso maior problema, pois inúmeras fatias dentárias foram perdidas durante esse procedimento. Os procedimentos de fixação (24h) e desmineralização (48h- 72h) foram seguidos conforme dita o protocolo do Dr. Antony Smith e outros trabalhos referentes 'a cultura de fatias dentárias ${ }^{76,81,88,125}$. Segundo informação do técnico Chris Strayhorn (Universidade de Odontologia de Michigan), o qual realizou os procedimentos histotécnicos referentes ao corte das amostras em parafina e coloração com $\mathrm{HE}$, o problema das perdas das amostras poderia estar relacionado com a espessura da fatia dentária o qual, no primeiro experimento, foi de $2 \mathrm{~mm}$. Devido a esse fato, optou-se pela espessura de $1.5 \mathrm{~mm}$ para os futuros experimentos com o intuito de proporcionar melhores condições para a realização dos procedimentos histotécnicos, tanto para o estudo in vitro como para o futuro trabalho in vivo. Ressaltamos que a espessura de $1 \mathrm{~mm}$ foi também testada, porém não apresentou bons resultados. A idéia de embeber as amostras em plástico (COLBATZKY \& HERMANNS ${ }^{22}$, 1987) foi também questionada, porém o 
problema não estava relacionado com esta etapa, nem mesmo com o processo de desmineralização, e sim com a espessura das amostras e sua retenção na parafina. Retenções adicionais foram confeccionadas com broca em altarotação na superfície externa da raiz dentária, na face vestibular e palatina ou lingual, antes da descontaminação, como tentativa de melhorar a retenção das amostras na parafina, porém o problema persistiu não sendo solucionado com esta manobra. Após discussões com o Dr Nör, Dr. Holland e o técnico Chris, aceitamos a sugestão de remover a dentina ao redor do tecido pulpar, previamente ao procedimento histotécnico em algumas amostras, incluindo na parafina somente o tecido pulpar.

Foram 3 meses de trabalho para se instituir um domínio técnico da metodologia, não somente relacionada à obtenção e corte das fatias dentárias, mas também relacionada a todas as etapas necessárias à cultura celular das mesmas.

O período de cultura das fatias dentárias foi estabelecido inicialmente por 7 dias, com o intuito de verificar se se conseguiria reproduzir a cultura celular das fatias dentárias humanas realizada e referenciada pelo Prof. Antony Smith (MURRAY et $\mathrm{al}^{87,88}, 2000,2002$ ). Não tivemos o objetivo de estendê-lo para períodos mais longos, como já visto em alguns trabalhos de cultura celular (MAGLOIRE; JOFFRE; BLEICHER ${ }^{76}$, 1996, SLOAN et al. ${ }^{125}$, 1998 em dentes de ratos), pois os resultados obtidos em 7 dias ofereceram dados suficientes que instigaram ainda mais a realização do estudo in vivo, objetivo primordial desta pesquisa.

O presente traballho se diferenciou das demais publicações envolvendo cultura de fatias dentárias humanas em inúmeras situações, mas principalmente pelo fato de que nesta pesquisa questionou-se o possível efeito do VEGF-165, proteína recombinante humana, ou seja, fator de crescimento vascular endotelial no tecido pulpar submetido à cultura celular, através da adição do mesmo ao meio de cultura objetivando, dessa forma, verificar o efeito desse fator de crescimento na angiogênese da polpa humana e na apoptose celular. A quantidade de VEGF (50ng/ml adicionada ao meio de cultura utilizada nesta pesquisa seguiu a recomendação dos trabalhos publicados por NÖR et al. ${ }^{95}, 2001$, NÖR et al. ${ }^{96}, 2002$. Com relação ao meio de cultura (DMEM), a quantidade do mesmo em cada reservatório individual, o 
tamanho dos reservatórios $(6,12)$ e a utilização ou não de matrigel para a estabilização da fatia dentária foram indagações respondidas com 0 desenvolvimento do projeto- piloto. Verificou-se que o reservatório com 12 espaços individuais proporcionou uma ótima estabilização da fatia dentária, impedindo a movimentação da mesma no meio de cultura. Cada reservatório individual foi preenchido com 1ml de DMEM (MURRAY \& SMITH ${ }^{87}, 2002$ ), quantidade suficiente para cobrir a amostra. Outros trabalhos indicam o uso de $4 \mathrm{ml}$ de meio de cultura, porém os mesmos não utilizam o reservatório de 12 espaços individuais e sim a placa ou disco de petri para cultura das fatias dentárias $^{76,88,125}$. A troca do meio de cultura foi realizada a cada dois dias, de acordo com os trabalhos de MAGLOIRE; JOFFRE; BLEICHER ${ }^{76}, 1996$, SLOAN et al. ${ }^{125}, 1998$, MURRAY et al. $\left.{ }^{88}, 2000\right)$.

Após inúmeros cortes, estando a metodologia padronizada e a obtenção notória de alguns resultados satisfatórios com a manutenção da dentina ao redor de cada fatia dentária, decidiu-se, então, realizar os procedimentos histotécnicos das amostras com metade dos espécimes mantendo a fatia dentária íntegra (com dentina ao seu redor), e a outra metade mantendo somente o tecido pulpar. A dentina foi removida com auxílio de uma lâmina afiada, com cuidado para não injuriar o tecido pulpar previamente fixado. Vinte amostras foram submetidas à cultura, sendo que 10 representaram o grupo controle (sem VEGF) e as 10 restantes representaram o grupo experimental (com VEGF). Perderam-se 2 amostras de cada grupo durante a confecção dos blocos de parafina e corte das secções histológicas. Então, os resultados basearam-se na quantidade de 8 amostras por grupo, ratificando com isso que o problema referente ao corte das amostras em parafina ainda deve ser revisado para futuros estudos. A espessura dos cortes em parafina $(7 \mu \mathrm{m})$, bem como a dos cortes para a realização da técnica imuno-histoquímica $(5 \mu \mathrm{m})$ foram realizadas de acordo com o protocolo do Laboratório de Histologia e Patologia da Universidade de Odontologia de Michigan.

Essa preocupação com a metodologia (in vitro) para obtenção das fatias dentárias foi minuciosa, pois através dos resultados obtidos definir-se-ia a condição da realização ou não da etapa subsequente e primordial desta pesquisa, ou seja, o desenvolvimento do experimento in vivo. 


\subsubsection{Estudo in vitro - cultura celular e RT-PCR}

Enquanto se aguardavam os 7 dias de cultura das fatias dentárias, bem como os procedimentos histotécnicos para posterior realização da técnica de imuno-histoquímica e do teste de tunel para detecção de células apoptóticas, foram desenvolvidas outras partes do trabalho in vitro relacionadas à cultura celular de: OD-21 (células pulpares indiferenciadas de camundongo -HANKS et al. ${ }^{49}, 1998$ ), MDPC-23 (células tipo odontoblasto de camundongo - HANKS et al. ${ }^{49}$,1998), HDMECs e macrófagos de camundongo (RAW 264.7, ATTCC, Manassas, VA, USA), seguindo os protocolos do Laboratório do Dr. Jacques Nör e trabalhos já publicados envolvendo cultura das mesmas (BOTERO et al. ${ }^{13}, 2003$, TELLES et al. ${ }^{133}$, 2003). Posteriormente, realizou-se a extração do RNA total das células (OD-21, MDPC-23, HDMEC e macrófagos) conforme a descrição no capítulo do Apêndice, para a realização da técnica de RT-PCR (Transcrição reversa- reação em cadeia de polimerase), com o objetivo de avaliar a expressão do receptor VEGFR-2 mRNA nas células já mencionadas.

A reação em cadeia de polimerase, quando parte do RNA, é chamada de transcrição reversa (RT-PCR). Essa técnica combina a síntese de cDNA, a partir de moldes de RNA, com PCR para fornecer um método rápido e sensível para análise da expressão gênica. RT-PCR é usada para detectar ou quantificar a expressão da mensagem, geralmente de pequenas quantidades de RNA ${ }^{97,113}$. Neste estudo, a RT-PCR foi realizada em uma única etapa com o auxílio do Super Script one step RT-PCR with Platinum Taq kit. Assim, a transcrição reversa e PCR ocorrem seqüencialmente em um único tubo, sob condições otimizadas, tanto para RT como para PCR, minimizando assim a contaminação, já que os tubos não precisam ser abertos entre a síntese de cDNA e amplificação ${ }^{97,113}$. No presente estudo, o controle endógeno, tanto para OD-21, MDPC-23, HDMEC como para macrófagos, foi realizado com o gene GAPDH, utilizado em estudos por NÖR et al. ${ }^{96}$, 2002, BOTERO et al. ${ }^{13}, 2003$, SONG et al. ${ }^{129}, 2004$, bem como no laboratório do Dr. Jacques Nör da 
Universidade de Michigan, onde foi realizado o RT-PCR, o qual, utiliza o gene GAPDH rotineiramente, fazendo parte do protocolo de padronização dos resultados dos experimentos lá desenvolvidos. Utilizou-se como controle positivo as células HDMECs devido ao fato de já se ter conhecimento de que as mesmas expressam VEGFR-2. O experimento foi repetido diversas vezes, sendo que as repetições iniciais foram realizadas devido a erros cometidos pela falta de prática com a técnica. Após o resultado obtido, realizaram-se mais 2 experimentos para a confirmação do mesmo.

\subsubsection{Estudo in vitro - Imuno-histoquímica}

O termo imuno-histoquímica compreende o processo de identificação de antígenos em secções de tecidos com o auxílio de anticorpos específicos. Essa reação se torna visível através de moléculas conjugadas aos anticorpos utilizados. Entretando, isso se faz adicionando a um sistema de detecção um anticorpo contra o antígeno de interesse.

O anticorpo utilizado nesta pesquisa foi policlonal. Os anticorpos policlonais possuem vários clones, ou seja, originam-se de diferentes linfócitos $B$, o que significa que reagem com vários epítopos do antígeno, ou seja, reconhecem mais de um epítopo em um mesmo antígeno. Já os monoclonais reagem apenas com um determinado epítopo presente em um antígeno (CARNEIRO $\left.{ }^{18}, 2006\right)$.

Sabe-se que todas as etapas que envolvem o processo da técnica de imuno-histoquímica são fundamentais para o sucesso da realização da mesma. A preservação dos epítopos antigênicos é um aspecto importante que se deve ressaltar na escolha da solução fixadora. No presente estudo, utilizamos a solução de formalina tamponada neutra $10 \%$ e o ácido fórmico $10 \%$, ambos protocolos utilizados na rotina do laboratório da Universidade de Michigan. A literatura é bastante vasta em relação ao assunto e existem inúmeros protocolos seguidos pelos diferentes centros de estudo, tanto para a solução de escolha para o processo de fixação como para o de descalcificação (MILLER; SWANDSON; WICK ${ }^{82}, 2000$ ). Os períodos de fixação (24h) e de 
desmineralização (48h) para fatias dentárias já foram alvo de discussão no tópico referente ao estudo in vitro- cultura das fatias dentárias.

Os cortes histológicos para a realização da imuno-histoquímica foram obtidos com $5 \mu \mathrm{m}$ de espessura, em micrótomo rotatório, de acordo com a rotina do laboratório de histologia e patologia da Universidade de Michigan, diferenciando-se da rotina utilizada em outros centros de estudo, bem como em outros trabalhos $\left(\right.$ CARNEIRO $\left.{ }^{18}, 2006\right)$ que utilizam o corte em $3 \mu \mathrm{m}$.

Um tópico bastante discutido quando da realização de imunohistoquímica se refere ao procedimento da recuperação antigênica. Encontramos na literatura diferentes fontes de produção de calor para se realizar a recuperação antigênica, incluindo o aquecimento em microondas, a utilização do banho-maria, a utilização de panelas de pressão e autoclaves (MILLER; SWANDSON; WICK ${ }^{82}$, 2000). Utilizamos nesta pesquisa, para a exposição antigênica, o banho-maria por 20 minutos, mantendo a temperatura entre $92^{\circ} \mathrm{C}$ e $95^{\circ} \mathrm{C}$, seguindo o protocolo para realização da técnica de imunohistoquímica do Laboratório de pesquisa do Dr. Jacqües Nör.

A utilização do microondas para a exposição antigênica tem sido alvo de questionamento, sendo condenada por alguns autores pelo fato de esta manobra promover irregularidades no aquecimento produzido. Além desse fato, o grau e a uniformidade do aquecimento variam de acordo com a quantidade de material processado. Um outro problema com o aquecimento produzido pelo microondas está relacionado à evaporação da solução, pois para evitar-se o ressecamento dos cortes deve haver um monitoramento e uma nova complementação da solução (MILLER; SWANDSON; WICK ${ }^{82}, 2000$ ).

Para as células endotelias (vasos sangüíneos) do tecido pulpar, 0 anticorpo utilizado foi o Fator de Von Willebrand - Fator VIII, ref. RB-281-A, NeoMarks Fremont, CA, diluído na proporção de 1:500. O processo de diluição é indicado pelo fabricante e a realização da técnica seguiu o protocolo de imuno-histoquímica para Fator VIII do laboratório do Dr. Jacques Nör da Universidade de Michigan.

O fator de von Willebrand (FVIII RAg) e Fator VIII formam um complexo biomolecular, sendo este um fator de coagulação sangüínea essencial para o processo de hemostasia normal nas células endoteliais, que revestem os vasos sangüíneos de tecidos pulpares humanos normais e em 
processo inflamatório (JACOBY et al. ${ }^{57}$, 1991). Nas células endoteliais humanas, os corpúsculos de Weibel- Palade são organelas especializadas e peculiares que desempenham algum papel no processo de coagulação sangüínea, já que tais estruturas armazenam o Fator de von Willebrand, antígeno relacionado com o Fator VIII (RUGGERI; ZIMMERMAN ${ }^{111}$, 1987). O fator de von Willebrand é um polímero com subunidades de 220 kDa. Funciona como um veículo carreador para o fator VIII e é encontrado no plasma humano na concentração de 5 a $10 \mu \mathrm{g} / \mathrm{ml}$, tendo sido identificado no citoplasma das células endoteliais, megacariócitos e plaquetas (RUGGERI; ZIMMERMAN ${ }^{111}$, 1987). Entretando somente as células endoteliais e megacariócitos sintetizam o fator de von Willebrand (JAFFE; HOYER; NACHMAN ${ }^{58}$, 1974).

Jacoby et al. ${ }^{57}, 1991$, demostraram que todas as classes de vasos sangüíneos (capilares, arteríolas, artérias, vênulas e veias) foram positivas à presença do fator de von Willebrand pela imunomarcação. Com base nesses resultados, não houve a necessidade de se realizar um controle positivo em nossa pesquisa.

A imunomarcação para o fator de Von Willebrand (específico para células endoteliais- vasos sangüíneos) tanto no estudo in vitro com no in vivo foi realizada com o objetivo de se verificar a viabilidade do tecido pulpar, já que a presença de vasos sangüíneos ativos em qualquer tecido sugere que o mesmo ainda se encontra viável e, possivelmente, com aspectos de normalidade. Além disso, pode-se quantificar o número de vasos sangüíneos de acordo com os trabalhos de NÖR et al. ${ }^{94}, 2001$ e SONG et al. ${ }^{129}, 2004$, possibilitando, dessa forma, no caso desta pesquisa, uma análise do efeito do VEGF sobre o tecido pulpar humano após a cultura.

Utilizou-se, como protocolo de imunomarcação, o método da imunoperoxidase (Streptoavidina-Biotina), já realizado em alguns estudos de imuno-histoquímica (JACOBY et al. ${ }^{57}$, 1991, MATTUELLA ${ }^{80}, 2005$ e de CARNEIRO $^{18}$, 2006). Para a realização da técnica utilizou-se o kit da Dako Cytomation Envision +Sistema Streptavidin-HRP (AEC). Esse método de coloração é de alta sensibilidade e explora a capacidade de conjugação de 100 moléculas de enzimas e 20 moléculas de anticorpos em uma cadeia de dextrana, formando um polímero de anticorpos e enzimas. A conjugação ocorre sem destruição da reatividade do anticorpo e permite aumentar a sensibilidade 
da coloração com redução do número de etapas. Assim, a seqüência é composta da aplicação do anticorpo primário, anticorpo secundário marcado com a enzima e substrato.

\subsubsection{Estudo in vitro - Teste do Tunel (In situ cell death detection kit,} AP)

O maior mecanismo fisiológico de remoção celular é o fenômeno de apoptose (ISRAELS; SRAELS ${ }^{56}$, 1999). A maioria dos tecidos sofre um freqüente processo de renovação celular, mantendo constante o número de células, graças ao equilíbrio existente entre a contínua proliferação e morte das células. Nesse caso, trata-se de uma forma fisiológica normal de morte celular que se caracteriza por um processo ativo de alterações morfológicas e fisiológicas, conhecido como apoptose (JORDÃO; ANDRADE ${ }^{61}$, 2000). Muitas vezes, essa morte por apoptose é também conhecida como morte celular programada, porque envolve a ativação de um programa genético para o desmantelamento da célula (JORDÃO; ANDRADE ${ }^{61}, 2000$ ).

A apoptose é essencial em muitos processos fisiológicos, incluindo, entre eles, o desenvolvimento do tecido embrionário, do tecido nervoso e o processo de reparo e remodelação tecidual (NÖR; POLVERINI ${ }^{92}$, 1999). A regulação inapropriada do processo de apoptose celular pode desempenhar um importante papel no desenvolvimento de inúmeras condições patológicas como isquemias, doenças cardíacas, câncer, SIDA, hepatotoxicidade e doenças degenerativas do sistema nervoso central. A remoção de neutrófilos da resposta inflamatória, a morte celular ocorrida pela utilização de agentes quimioterápicos-antineoplásicos são alguns exemplos de remoção celular pelo processo de apoptose (ISRAELS; ISRAELS ${ }^{56}$, 1999).

As mudanças morfológicas que ocorrem durante a apoptose incluem a fragmentação do DNA, resultante de clivagens entre os nucleossomos, a condensação da cromatina e a fragmentação nuclear em pequenos núcleos, o que dá à célula o aspecto granulado. Mitocôndrias também apresentam modificações fisiológicas com a apoptose, entre as quais 
se incluem mudanças no transporte de elétrons, liberação de ativadores de caspases e alteração no potencial de oxi-redução (JORDÃO; ANDRADE ${ }^{61}$, 2000). Há uma quebra na arquitetura do citoesqueleto, a célula se contrai e se fragmenta em vesículas revestidas por membrana denominadas corpos apoptóticos (JORDÃO; ANDRADE ${ }^{61}$, 2000, ISRAELS; ISRAELS ${ }^{56}$, 1999). Pelo fato de serem revestidas por membrana, esses fragmentos são reconhecidos e fagocitados pelos macrófagos ou por células vizinhas. As células que morrem por apoptose são removidas do tecido sem que haja extravasamento de conteúdo celular, o que, normalmente, é a causa da inflamação (JORDÃO; ANDRADE $^{61}$, 2000). Como esses corpos apoptóticos não induzem significante liberação de citocinas pelas células fagocitárias, o processo progride sem indução concomitante de uma resposta inflamatória (ISRAELS; ISRAELS ${ }^{56}$, 1999).

Este presente trabalho identificou e quantificou células apoptóticas nos cortes histológicos do tecido pulpar das fatias dentárias submetidas a cultura por 7 dias (in vitro), e identificou, também, através da marcação, as células apoptóticas nos cortes provenientes do estudo in vivo resultado da implantação das fatias dentárias no subcutâneo dos camundongos imunodeprimidos (avaliação qualitativa). Para a mensuração da morte celular, tanto no estudo in vitro como no estudo in vivo, utilizou-se o teste do tunel (In situ cell death detection kit, AP - cat. $N^{\circ} 1684809$ - Roche $)^{55}$, seguindo-se as instruções do fabricante e algumas publicações ${ }^{59,94,95,96,129,131}$. Esse teste proporcionou, por meio da visualização através do microscópio de transmissão de luz, a detecção das quebras nas cadeias de DNA nas células apoptóticas individuais. A marcação enzimática permite a detecção de um evento apoptótico mesmo antes de ocorrer alteração na morfologia e mesmo antes que o fragmento de DNA torne-se detectável no citoplasma. Ele pode detectar também estágios precoces da fragmentação de DNA nas células apoptóticas. Esta consideração é importante, especialmente nos casos em que o processo de apoptose é estudado in vivo, por exemplo nos cortes teciduais, pois as células apoptóticas são rapidamente e eficientemente removidas in vivo (http://www.roche-applied-science.com/pack-insert/11684809910a.pdf $)^{55}$.

Para a visualização da marcação das células apoptóticas, o fabricante indica a utilização da solução Fast Red ou a utilização do substrato 
de fosfatase alcalina (BCIP/NBT). Após a verificação dos resultados obtidos com o Fast Red, optou-se pela utilização do substrato de fosfatase alcalina BCIP/NBT- working solution Cat $n^{\circ}$ SK- 5400, responsável pela coloração azul escuro. Novamente, tentando seguir as orientações do fabricante, procuramos realizar a coloração de fundo com $5 \%$ de metila verde (methyl green) ou com a hematoxilina, porém ambas as colorações não ofereceram um bom contraste com a marcação azul escuro das células apoptóticas; por essa razão optou-se pela não-realização da coloração de fundo.

Realizou-se o controle negativo seguindo-se as etapas para a realização do teste de Tunel indicadas pelo fabricante. Porém, neste caso, a mistura completa para reação de Tunel não foi aplicada nos cortes, mas somente foi aplicado um dos reagentes da mistura a Label solution (sem terminal transferase). Não ocorreu, dessa forma, a detecção da área de fragmentação do DNA.

A realização do teste de Tunel, nesta pesquisa, teve como objetivo tentar verificar a existência ou não de uma correlação entre o efeito do VEGF na angiogênese pulpar, revascularização e o processo de apoptose celular.

\subsubsection{Estudo in vivo}

O modelo de estudo da angiogênese humana utilizando camundongos imunodeprimidos (SCID mouse) fez parte de uma investigação desenvolvida no laboratório do Dr. Jacques Nör, sendo encontrado na literatura em algumas de suas publicações ${ }^{94,95,96}$ e servindo como uma referência para o estudo do desenvolvimento fisiológico da microcirculação, estudo das respostas neovasculares patológicas, como no caso da angiogênese tumoral, e para o desenvolvimento e investigação de estratégias designadas para 0 melhoramento no processo de neovascularização na engenharia de tecidos e órgãos humanos. Esse modelo demonstrou que a implantação de matrizes de polímero biodegradáveis contendo células endoteliais humanas (HDMECs), no subcutâneo dos camundongos imunodeprimidos, resultou na diferenciação das 
mesmas em microvasos humanos funcionais que se anastomosaram com a vasculatura do camundongo imunodeprimido.

A partir de então, esse modelo vem sendo mencionado e realizado por outros pequisadores em suas publicações envolvendo estudos de terapia genética antiangiogênica (SONG et al. ${ }^{129}$, 2004).

Neste trabalho procurou-se associar os conhecimentos adquiridos com a metodologia proposta pelo Dr. Nör, no que se refere ao modelo de estudo da angiogênese humana, com as publicações do Dr. Antony Smith, que preconizava o estudo de fatias dentárias humanas em cultura. A associação dessas duas metodologias teve como princípio trazer esses conhecimentos para a área da Odontologia, especialmente nas especialidades que necessitam de uma melhor compreensão da angiogênese da polpa dentária humana, dentre elas a especialidade de Endodontia, em que o processo de revascularização pulpar em casos de reimplante dentário, principalmente em dentes com rizogênese incompleta, não está ainda bem elucidado. A carência de um modelo de estudo in vivo utilizando a implantação de fatias dentárias com tecido pulpar humano no subcutâneo de camundongos imunodeficientes instigou a realização desta metodologia. Sabe-se que muitos dos estudos in vivo desenvolvidos na especialidade de Endodontia foram realizados utilizando polpas dentárias de origem não humana e que, na maioria das vezes, quando se encontram trabalhos realizados utilizando polpa humana, os mesmos não estão voltados para a elucidação do papel dos genes humanos, o papel das proteínas pro-apoptóticas na angiogênese pulpar. Além disso, a polpa dental de roedores como os ratos e camundongos respondem à terapia de modo significantemente diferente quando comparado à resposta da polpa humana. Por essa razão, a pesquisa foi baseada na implantação de fatias de dentes humanos em subcutâneo de camundongos imunodeprimidos (SCID). Com a criação deste modelo de estudo abriu-se o caminho para que essas informações sejam obtidas em futuras pesquisas, envolvendo os conceitos da Biologia molecular, as quais, poderão elucidar e proporcionar novas diretrizes para o protocolo de tratamento em casos de reimplante dentário, especialmente em dentes com rizogênese incompleta.

Para a realização deste estudo, foram utilizados camundongos imunodeficientes (CB.17. SCID) fêmeas, pesando em média 18 
a 25 gramas, estando de acordo com os trabalhos de NÖR et al. ${ }^{94,95}, 2001$, NÖR et al. ${ }^{96}$, 2002, POLVERINI ${ }^{103}, 2002$ e POLVERINI et al. ${ }^{104}, 2003$. Os procedimentos cirúrgicos foram realizados em animais com 10 semanas de vida. Os animais foram obtidos do Laboratório do Charles River, após a aprovação da Comissão de ética da Universidade de Odontologia de Michigan para pesquisas envolvendo animais, projeto UCUCA 8754.

Todos os procedimentos cirúrgicos, entre eles os anestésicos (ketamina, xilazina), técnica de anestesia (intraperitonial -IP), 0 tamanho da incisão $(1 \mathrm{~cm})$, o uso de Vetbond, cola adesiva cobrindo toda a extensão da incisão em vez da sutura convencional, os cuidados com o manuseio do animal pré e pós-operatório, já descritos no capítulo de materiais e métodos, foram realizados seguindo as orientações do manual institucional de pesquisas envolvendo animais da Universidade de Michigan (UCUCA) e os trabalhos de NÖR et al. ${ }^{94,95}, 2001$, NÖR et al. ${ }^{96}, 2002$, POLVERINI ${ }^{103}, 2002$, POLVERINI et al. ${ }^{104}, 2003$ e SONG et al. ${ }^{129}, 2004$.

A maioria dos trabalhos envolvendo a implantação de matriz de polímero biodegradável contendo células utilizou dois implantes por animal $^{94,95,96,103,104,129}$. No presente estudo, devido aos problemas encontrados no processo de obtenção dos cortes histológicos provenientes das fatias dentárias em cultura, preferimos utilizar quatro fatias dentárias por animal, sendo distribuídas duas no lado direito (superior e inferior) e duas no lado esquerdo (superior e inferior).

Utilizamos seis animais para a realização deste estudo, pois além do custo do camundongo imunodeprimido ser muito alto, não só do animal em si, mas da sua manutenção e dos cuidados pré e pós-operatórios, não foi necessária uma amostra maior para verificação dos resultados obtidos. O comitê de ética da Universidade de Michigan, envolvendo o uso de animais em pesquisa laboratorial, é bastante rígido nesse sentido.

As fatias dentárias permaneceram 7 dias no subcutâneo do camundongo imunodeficiente, já que, de acordo com o trabalho de NÖR et al., 2001, os implantes (matriz de polímero biodegradável contendo células) mantidos em cinco dias no subcutâneo de camundongos imunodeficientes tornaram-se encapsulados pelo tecido conjuntivo fibroso permeado pelos vasos sangüíneos demonstrando, entre o período de 7 a 10 dias, a diferenciação das 
células endoteliais em microvasos funcionais. Dessa forma, optamos pelo período de sete dias para se verificar o estado de normalidade ou não do tecido pulpar após a implantação das fatias dentárias. Após esse período, os animais foram mortos pela técnica de deslocamento cervical.

\subsection{RESULTADOS}

Fazendo uma breve recapitulação para se iniciar a discussão dos resultados encontrados aqui neste estudo, os objetivos desta pesquisa foram avaliar o efeito do VEGF na angiogênese e na apoptose da polpa dentária humana, e desenvolver um modelo (in vivo) para o estudo do processo de revascularização da mesma.

Sabe-se que o VEGF é um fator de crescimento mitógeno para as células endoteliais e, portanto, um potente fator angiogênico $33,34,35,36,37,38,39,40,41,42$. Tem sido considerado um dos responsáveis pela promoção de revascularização dos tecidos isquêmicos ${ }^{10,48,70}$ e formação de vasos sangüíneos (YANCOPOULOS et al. ${ }^{143}$, 2000). A maioria dos estudos - apontam como 0 maior regulador da angiogênese fisiológica ${ }^{33,34,35,36,37,38,39,40,41,42}$. O VEGF apresenta três RTK, VEGFR-1, o VEGFR-2 e o VEGFR-3 (FERRARA ${ }^{42}$, 2003, HOEBEN et al. ${ }^{53}$, 2004, HICKLIN; $E_{L L I S}{ }^{52}$, 2005). O VEGFR-1 e o VEGFR-2 são expressos pelas células endoteliais da parede vascular. A união do VEGF a esses receptores inicia uma cascata de eventos que finalmente estimula o crescimento/ sobrevivência e proliferação das células do endotélio vascular (http://wwww.Anti$\underline{\text { VEGF.com.br/publico/ciencia } 1 \mathrm{htm}} .{ }^{32}$ / NÖR et al. ${ }^{95}$, 2001). As células endoteliais desempenham funções em variados processos como vasoconstrição/ vasodilatação, apresentação de antígenos e são componentes essenciais dos vasos sangüíneos, capilares, veias e artérias. Portanto, ao estimular as células endoteliais, o VEGF desempenha um papel central na angiogênese.

Com base nos conhecimentos adquiridos através da literatura sobre o VEGF, a ciência odontológica voltou seus estudos para a 
área de Biologia Molecular, Genética e Engenharia Tecidual para dar início a uma nova fase da Odontologia, fase esta mais voltada para o aspecto biológico propriamente dito.

Sabe-se que ainda hoje, um dos fatores limitantes para a evolução no tratamento de dentes avulsionados é a carência de um bom modelo para se estudar o processo de revascularização/angiogênese da polpa dentária humana. Inúmeros trabalhos na Odontologia foram e têm sido desenvolvidos para melhor compreensão da relação do fator de crescimento vascular endotelial (VEGF) na Biologia Pulpar (MATSUSHITA et al. ${ }^{78}$, 1999, MATSUSHITA et al. ${ }^{79}$, 2000, ROBERTS-CLARK; SMITH ${ }^{108}, 2000$, ARTESE et al. $^{5}, 2002$, BOTERO et al. $^{13}$, 2003, TELLES et al. ${ }^{133}$, 2003, DERRINGER; LINDE ${ }^{25}$, 2003, DERRINGER; LINDE ${ }^{26}$, 2004; MANTELLINI et al. ${ }^{77}, 2003$, SODEN $\left.^{127}, 2005\right)$, bem como a detecção e a avaliação de seus receptores, in vitro. Este tópico é encontrado nos trabalhos de MATSUSHITA et al. ${ }^{79}, 2000$, na pesquisa com citometria de fluxo de células em cultura primária. $E$ no trabalho de MATTUELLA ${ }^{80}$ (2005) que detectou, por meio da técnica de imunohistoquímica para VEGFR-2, que as células pulpares endoteliais de dentes decíduos e permanentes jovens expressaram o VEGFR-2, sendo que uma intensidade maior foi observada nos dentes decíduos por meio da imunomarcação. Porém a função ou efeito que o VEGF desempenha na polpa dentária permanece desconhecido (BOTERO et al. ${ }^{13}, 2003$ ).

Este trabalho envolveu o uso do modelo de cultura de órgãos utilizando fatias dentárias, para o estudo da polpa dentária, o qual foi descrito por SLOAN et al. ${ }^{125}$, 1998, MURRAY et al. ${ }^{88}, 2000$ e MURRAY; $\mathrm{SMITH}^{87}$ em 2002, combinando os princípios básicos dos trabalhos de MAGLOIRE; JOFFRE; BLEICHER ${ }^{76}$, 1996, que analisaram, por meio da cultura de fatias dentárias humanas, o comportamento do tecido pulpar seguido de preparo cavitário dentinário. Os autores sugeriram, através de seus resultados, que esse modelo de cultura (fatias dentárias) foi um método útil para se testarem os fatores que regulam o processo de reparo da polpa dentária, já que a mesma demonstrou, in vitro, sua recuperação após a injúria, estando de acordo com o trabalho de PARRISH; GANDOLFI; BRENDEL ${ }^{100}$, 1995, o qual enfatizam que a cultura de fatias dentárias é um modelo de estudo in vitro que 
mantém a interação normal entre as células tanto quanto a integridade microvascular do tecido.

Nosso estudo demonstrou o efeito de $50 \mathrm{ng} / \mathrm{ml}$ da proteína recombinante humana VEGF-165, (isoforma mais amplamente utilizada) aplicada ao tecido pulpar submetido a cultura pelo período de 7 dias. A viabilidade do complexo foi mantida durante todo o período, apresentando uma boa preservação celular e morfologia tecidual, estando de acordo com os trabalhos de MAGLOIRE; JOFFRE; BLEICHER ${ }^{76}$, 1996, os quais demonstraram que o complexo dentina/polpa das fatias dentárias humanas manteve sua viabilidade celular por longos períodos de cultura. Deve-se ressaltar que esse modelo para cultura de órgãos (fatias dentárias), utilizado nesta pesquisa, providenciou a oportunidade para a manipulação de tecidos pelo fato de o mesmo ser imerso em um meio de cultura com VEGF. O uso de soro bovino fetal inativado pelo calor como um suplemento de crescimento no meio de cultura facilitou o estudo do efeito do VEGF sobre o comportamento tecidual (SLOAN et al. ${ }^{125}$, 1998). A longa manutenção da morfologia fenotípica dos odontoblastos pode estar correlacionada à presença de tecido dentinário, 0 contato entre ambos é requerido para que o odontoblasto mantenha sua morfologia e atividade secretora (HEYWOOD; APPLETON ${ }^{51}$, 1984), ou pelos componentes da matriz dentinária (TZIAFAS; KOLOKURIS ${ }^{137}$, 1990, TZIAFAS; ALVANOU;KAIDOGLOU ${ }^{138}$, 1992, TZIAFAS et al. ${ }^{139}$ 1992., SMITH et al. ${ }^{126}$, 1994) liberados durante o provável processo de desmineralização produzido pelo ácido ascórbico presente no meio de cultura. Porém, em algumas lâminas, observamos que a camada odontoblástica não se manteve totalmente íntegra, apresentando a mesma alguns espaços vazios ou vacúolos, com odontoblastos de forma cubóide diferenciando- se da sua forma original mais alongada. Mesmo com a presença de alterações celulares, o tecido pulpar manteve-se com aspectos de normalidade (Figura A- DISCUSSÃO), estando de acordo com os resultados de MAGLOIRE; JOFFRE; BLEICHER ${ }^{76}$, 1996, que também relataram mudanças morfológicas na camada odontoblástica, permanecendo tecido pulpar com aspectos de normalidade após a cultura. 

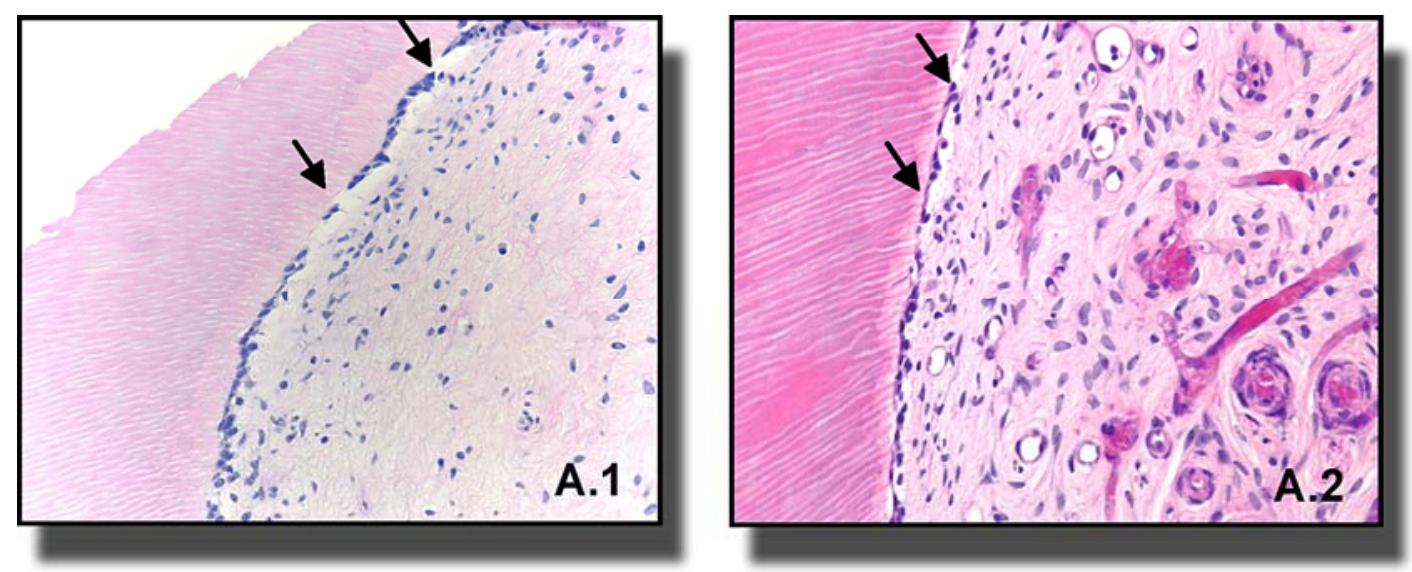

Figura A - Aspectos da camada odontoblástica, morfologia dos odontoblastos e aspectos de normalidade do tecido pulpar após o período de 7 dias em cultura com VEGF (A.1) e após a implantação das fatias dentárias no subcutâneo dos camundongos imunodeficientes (A.2). HE com 400x de magnificação.

Nosso critério para considerar microscopicamente a ocorrência de uma revascularização, através da coloração de $\mathrm{HE}$, foi a presença de um tecido vital (tecido pulpar com presença de camada odontoblástica, com vasos sangüíneos, fibroblastos, outros tipos celulares na região central e áreas com fibras colágenas) sem a evidência de reação inflamatória, mas com poucas imagens sugestivas de degeneração celular; estando de acordo com os critérios utilizados por SKOGLUND; TRONSTAD ${ }^{124}$, 1981 e RITTER et al. ${ }^{107}, 2004$ em seus trabalhos. A ausência de angiogênese e revascularização levaria a morte do tecido pulpar após esse período de 7 dias.

A técnica Imuno-histoquímica com anticorpos para o Fator de Von Willebrand (Fator VIII) demonstrou que o tecido pulpar no grupo experimental $(50 \mathrm{ng} / \mathrm{mL}$ VEGF) promoveu uma diferença significante $(p<0.05)$ no número de vasos sangüíneos marcados (média de 67,8; dp 26,7) comparado com o grupo controle (média 46,2; dp 18,9) sem VEGF (tabela 1; figura 9). Encontramos na literatura alguns trabalhos que utilizaram o Fator VIII para a marcação das células pulpares endoteliais como o trabalho de ARTESE et al. ${ }^{5}, 2002$, e JACOBY et al. ${ }^{57}, 1991$, no qual os autores demonstraram que a marcação positiva para o Fator VIII nas células endoteliais não foi somente encontrada nos capilares, mas também nas arteríolas, vênulas, artérias e 
veias. Os vasos sangüíneos (artérias e arteríolas) foram intensamente marcados por este anticorpo, porém nem todos os vasos sangüíneos foram positivos para o Fator VIII, tanto em polpas saudáveis ou inflamadas (JACOBY et al. $\left.{ }^{57}, 1991\right)$. Nossa marcação também sugeriu marcação positiva para Fator VIII em capilares, artérias e arteríolas, porém em algumas lâminas pôde-se observar ausência de marcação em alguns vasos sangüíneos presentes. JACOBY et al. ${ }^{57}$, 1991, explicam que nem todas as células endoteliais possuem a organela chamada de corpos ou corpúsculos de WEIL-PALADE, responsável pelo armazenamento do Fator VIII. Assim, a ausência dessa estrutura no citoplasma das células endoteliais poderia ser a responsável pelo não-armazenamento do Fator VIII e, conseqüentemente, ser a responsável pelo ausência da imunomarcação.

Não sabemos exatamente o papel do VEGF no tecido pulpar, mas nossos resultados in vitro sugeriram que o VEGF (grupo experimental) pode promover um aumento no número de vasos sangüíneos (tabela 1; figura 9), porque a sua presença no meio de cultura pode proteger uma maior quantidade de células contra o processo de apoptose, especialmente as células endoteliais. Independentemente do fato de a análise estatística dos grupos (com e sem VEGF) para o teste de Tunel (identificação de células apoptóticas) não ter demonstrado diferença estatística significante entre eles (tabela 1; figura 10), esses dados estão de acordo com o trabalho de NÖR et al. ${ }^{93}, 1999$. Eles relataram que o VEGF tem demonstrado ser um potente mediador do processo de angiogênese, aumentando a sobrevivência das células endoteliais sustentando, desse modo, o processo de angiogênese pela indução da expressão de uma proteína antiapoptótica Bcl-2. Sabe-se que somente as células endoteliais têm o receptor do VEGF. Como conseqüência, sua sobrevivência é aumentada pelo tratamento com o mesmo, $\left(\mathrm{KERBEL}^{65}\right.$, 2000 , NOR et al. ${ }^{96}, 2002$ ) fato esse que será discutido subseqüentemente. As células endoteliais constituem o revestimento de todo o sistema vascular (RODD; BOISSONADE ${ }^{109}$, 2005). O ambiente criado pela sobrevivência das células endoteliais é extremamente necessário para a manutenção da vascularização pulpar.

De acordo com os conhecimentos, através da literatura, sabe-se que para que ocorra a transdução do sinal, não basta somente a 
proteína estar disponível na matriz extracelular (MEC). A presença de um receptor protéico é essencial para permitir a ligação da molécula sinalizadora. A partir desta ligação uma cascata de eventos (sinalização) é iniciada e o comportamento celular direcionado de acordo com o tipo de célula-alvo (JUNQUEIRA; CARNEIRO ${ }^{62}, 2000$, NÖR$^{91}$, 2005). Os estudos ainda hoje não relatam um entendimento completo sobre as propriedades individuais de cada receptor na sinalização do VEGF. O que se sabe é que o VEGFR-1 desempenha a função de um decoy-receptor, ou seja, ele atua de forma a limitar a ligação do VEGF ao VEGFR-2, modulando, assim, a sua atividade, sendo também um receptor capaz de gerar, de alguma forma, um sinal mitogênico (WALTENBERGER et al. ${ }^{142}$, 1994, FERRARA; GERBER; LeCOUTER $^{42}, 2003$, HICKLIN; ELLIS ${ }^{52}$, 2005). A literatura é unânime sobre as propriedades biológicas do VEGFR-2, caracterizando-o como um receptor de maior importância no processo de angiogênese e aumento dos efeitos da permeabilidade do VEGF, estando o mesmo envolvido no processo de diferenciação das células endoteliais (NEUFELD et al. ${ }^{89}, 1999$, FERRARA $^{35}$, 1999) quimiotaxia e sobrevivência celular (FERRARA; GERBER; LeCOUTER ${ }^{42}$, 2003, MOULD et al. ${ }^{86}$, 2005). Por essa razão, o VEGFR-2 foi um dos alvos deste estudo.

Nossos resultados, através da análise de RT-PCR, demonstraram que a expressão do VEGFR-2 mRNA foi observada nas células endoteliais da microvasculatura da derme humana - HDMECs, mas não nas outras 3 linhas celulares (células pulpares indiferenciadas de camundongo, OD-21 (HANKS et al. ${ }^{49}$, 1998), células do tipo odontoblasto de camundongo MDPC-23 (HANKS et al. ${ }^{49}$,1998) e macrófagos de camundongo (RAW 264.7, ATTCC, Manassas, VA, USA). Esse resultado nos possibilitou entender que o aumento ou proteção do número de vasos sangüíneos, na presença de VEGF no meio de cultura do grupo experimental, pode ter correlação com o fato de as células endoteliais demonstrarem, pela análise de RT-PCR, que possuem o receptor VEGFR-2 para o VEGF. Qualquer fenômeno que tenha ocorrido, seja revascularização, aumento do número de células e vasos, ou proteção das células e vasos já existentes, é decorrente da atuação do VEGF sobre as células endoteliais e não sobre as células específicas da polpa. O VEGF, como já relatado anteriormente, pode desempenhar um papel extremamente 
importante no crescimento endotelial, sobrevivência e função (MOULD et al. ${ }^{86}$, 2005).

KATSUBE et al. ${ }^{63}, 2005$, demonstraram em seus estudos o efeito da terapia genética com VEGF no processo de aceleração e aumento da angiogênese do osso necrótico. A extensão do processo de neoangiogênese foi significantemente maior no grupo tratado com VEGF do que no grupo controle após o período de uma semana pós-operatório. Não podemos comparar seus resultados com os da nossa pesquisa, mas simplesmente discutir o efeito positivo da terapêutica angiogênica com VEGF com o intuito de promover uma angiogênese, revascularização em tecidos isquêmicos, tópico este amplamente explorado na literatura atual (KORANSKY, ROBBINS, BLAU ${ }^{70}$, 2002, KLEIMAN et al. ${ }^{69}$, 2003, BARANDON et al. ${ }^{10}, 2004$, MOULD et al. ${ }^{86}, 2005$, GOUNIS et al. $\left.{ }^{48}, 2005\right)$.

No que se refere ao grupo controle (sem VEGF), a manutenção da vascularização pulpar e tecido com aspectos de normalidade podem ser explicados através dos resultados obtidos por BOTERO et al. ${ }^{13}$, em 2003, em que os autores sugeriram que as células MDPC-23 e OD-21 são importantes fontes celulares de VEGF na polpa dental. Além disso, a expressão de VEGF na matriz dentinária relatada por ROBERTS-CLARK; $\mathrm{SMITH}^{108}$, em 2000, sugere que o VEGF está também presente durante o processo de dentinogênese. Podemos, ainda, inferir que talvez outro fator de crescimento pró-angiogênico possa estar envolvido na sobrevivência do tecido pulpar. DERRINGER; LINDEN ${ }^{25}$, 2003, relataram que há evidência de que diferentes indivíduos possam apresentar diferentes níveis de fatores de crescimento angiogênicos.

Nós sabemos que os estudos in vitro são rápidos e reproduzíveis consistentemente, porém eles não nos permitem estudar as complexas interações fisiológicas que ocorrem in vivo (STATON et al. ${ }^{131}$, 2004).

Um dos fatores limitantes para o aprimoramento no tratamento de dentes imaturos avulsionados é a falta de um bom modelo para o estudo da revascularização/angiogênese da polpa dentária humana. Por essa razão, consideramos que um dos mais importantes resultados demonstrados nesta pesquisa foi a caracterização de um novo modelo de 
estudo para 0 processo de angiogênese pulpar humana utilizando camundongos imunodeprimidos. Isso permitiu que se combinassem os princípios básicos da metodologia de SLOAN et al. ${ }^{125}$, 1998, com a concepção da indução de vascularização nos camundongos imunodeprimidos, publicada por NÖR et al. ${ }^{94}, 2001$.

Sete dias após a implantação das fatias dentárias nos camundongos imunodeprimidos, observamos, com base nos resultados obtidos, a presença de um tecido pulpar vital com um significante número de vasos sangüíneos imunomarcados pelo fator VIII, células (HE), presença de camada odontoblástica (HE), poucas células apoptóticas (marcação pelo teste de Tunel) e um tecido pulpar sem qualquer evidência de reação inflamatória. Sugere-se que a vitalidade (vascularização) do tecido pulpar humano pode ser mantida pela anastomose entre os microvasos (microcirculação) funcionais organizados pelas células endoteliais com a vasculatura existente no camundongo, de acordo com o resultados dos trabalhos de NÖR et al. ${ }^{94}, 2001$, onde foi verificado anastomose entre as células endoteliais humanas transplantadas em matrizes biodegradáveis com a vasculatura já existente do camundongo imunodeprimido. A fatia dentária implantada, no momento de sua remoção, apresentou um tecido pulpar com aparência altamente vascularizada. Acreditamos que há muitas razões diferentes para o resultado bem sucedido com nosso modelo de estudo para angiogênese da polpa humana utilizando camundongos imunodeprimidos. Sugerimos, neste relato, algumas delas. Sabemos que existem muitos fatores de crescimento pró-angiogênicos, os quais podem estar envolvidos no processo de angiogênese. Este modelo de estudo in vivo foi realizado com sucesso pela primeira vez, na literatura, e abrirá caminho e novas diretrizes para a realização de inúmeros experimentos que poderão elucidar importantes questões na área da Endodontia, especialmente para os casos de reimplante dentário de dentes com rizogênese incompleta, cuja única forma de tratamento, hoje em dia, é a espera da revascularização fisiológica. Os resultados obtidos com o VEGF no estudo in vitro serviram para fornecer um pouco mais de conhecimento em relação ao efeito benéfico do VEGF sobre o tecido pulpar humano, já que, em muitas situações clínicas, como no caso do reimplante dentário, o aumento da 
vascularização é uma premissa desejada. Nesse caso, o VEGF seria aplicado no ápice radicular e não promoveria o aumento da pressão intra-pulpar.

Com base nos resultados desta pesquisa, propomos a realização de futuros trabalhos utilizando este modelo de estudo para se confirmarem os resultados obtidos in vitro com o VEGF. Quem sabe, em um futuro próximo, poderemos instituir no protocolo de tratamento de dentes avulsionados, num primeiro momento em casos de rizogênese incompleta, a aplicação desse fator pró-angiogênico (VEGF). Sabemos que a procura por soluções e materiais ideais para qualquer área de conhecimento dentro da Odontologia, atualmente, deve estar direcionada ao conhecimento de proteínas expressas pelo nosso próprio organismo as quais, com o auxílio dos princípios de Biologia Molecular e Terapia Genética poderão vir a ser investigadas para que, desse modo, os resultados laboratoriais possam ser transportados para a clínica odontológica. 
120 
7 - CONCLUSÕES 



\section{7 - CONCLUSÕES}

Com base nos resultados deste trabalho pode-se concluir que:

1. O modelo de cultura de tecido pulpar in vitro foi considerado adequado à avaliação da angiogênese pulpar;

2. O fator de crescimento VEGF apresentou-se eficiente uma vez que:

2.1 A técnica de imuno-histoquímica mostrou maior número de vasos sangüíneos no grupo tratado com VEGF do que no controle;

2.2 O teste de Tunel evidenciou menor número de células apoptóticas no grupo tratado com VEGF do que no controle, apesar de não haver diferença estatística significante;

2.3 A coloração HE mostrou tecido pulpar vital em ambos os grupos.

3. O modelo de estudo da angiogênese pulpar humana utilizando camundongos imunodeprimidos apresentou-se adequado para responder a futuras indagações que envolvem o processo de angiogênese pulpar e o estudo de processos de revascularização pulpar. 

REFERÊNCIAS BIBLIOGRÁFICAS 



\section{REFERÊNCIAS BIBLIOGRÁFICAS}

1. AMERICAN ASSOCIATION OF ENDODONTICS. Treating the avulsed permanent tooth. 2004. Disponível em: www.aae.org- Data de acesso: 4 de Jun. de 2006.

2. ANDREASEN, J. O.; ANDREASEN, F. M. Textbook and color atlas of traumatic injuries to the teeth. Saint. Louis: Mosby, 1994.

3. ANDREASEN, J. O.; ANDREASEN, F. O. Avulsões. In: Textos e atlas colorido de traumatismo dental. 3.ed. Porto Alegre: Artmed Editora, 2001. Cap. 10, p.383-420.

4. ANDREASEN, J. O. et al. Replantation of 400 avulsed permanent incisors. Part I. Diagnosis of healing complications. Endod Dent Tramatol, Copenhagen, v.11, n. 2, p.51-58, Apr. 1995.

5. ARTESE, L. et al. Vascular endothelial growth factor (VEGF) expression in healthy and inflamed human dental pulps. J Endod, Chicago, v. 28, n. 1, p.20-3, Jan. 2002.

6. ASHKENAZI, M.; SARNAT, H.; KEILA, S. In vitro viability, mitogenicity and clonogenic capacity of periodontal ligament cells after storage in six different media. Endod Dent Tramatol, Copenhagen, v. 15, n. 4, p. 149156, Aug. 1999.

7. AUERBACH, R.; AUERBACH, W. Vasculogenesis and angiogenesis. In: . FAN, T.D.; KOHN, E. C. The new angiotherapy, Totowa: Humana Press, 2002. Cap.1, p. 1-6.

8. BAGRI, A.; TESSIER-LAVIGNE, M. Neuropilins as semaphorin receptors: in vivo functions in neuronal cell migration and axon guidence. Adv Exp Med Biol, New York, v. 515, p. 13-31, 2002.

9. BANCHS, F.; TROPE, M. Revascularization of immature permanent teeth with apical periodontitis: new treatment protocol? J Endod, Chicago, v. 30, n. 4, p.196-200, Aug. 2004. 
10. BARANDON, L. et al. Gene therapy for chronic peripheral arterial disease: what role for the vascular surgeon? Ann Vasc Surg, New York, v.18, n. 6, p. 758-765, Nov. 2004.

11. BERKOVITZ, B. K. B.; HOLLAND, G. R.; MOXHAM, B. J. Polpa dentária. In: Anatomia, embriologia e histologia bucal. 3.ed. Porto Alegre: Artmed; 2002. Cap. 10, p. 149-167.

12. BООTH, V. et al. Vascular endothelial growth factor in human periodontal disease. J Periodont Res, Copenhagen, v. 33, p. 491-499, Aug. 1998.

13. BOTERO, T. M. et al. Effect of lipopolysaccharides on vascular endothelial growth factor expression in mouse pulp cells and macrophages. Eur $\mathbf{J}$ Oral Sci, Copenhagen, v. 111, n. 3, p. 228-234, June 2003.

14. BUTTKE, T. M.; TROPE, M. Effect of catalase supplementation in storage media for avulsed teeth. Dent Traumatol, Copenhagen, v. 19, n. 2, p.103108, Apr. 2003.

15. ÇAGLAR, E.; TANBOGA, I.; SUSAL, S. Treatment of avulsed teeth with Emdogain. Dent Traumatol, Copenhagen, v. 21, n. 1, p. 51-53, Feb. 2005.

16. CARLILE, J. et al. Vascular endothelial growth factor (VEGF) expression in oral tissues: possible relevance to angiogenesis, tumor progression and field cancerisation. J Oral Pathol Med, Copenhagen, v. 30, n. 8, p. 449457, Sept. 2001.

17. CARMELIET, P.; JAIN, R. K. Angiogenesis in cancer and other. Nature, London, v.407, n. 7, p. 249-257, Sept. 2000

18. CARNEIRO, E. Análise da expressão de MMP-2, -9, -14, TIMP-1, -2 e RECK em granulomas e cistos periapicais. Bauru, 2005. 98p. Tese (Doutorado) - Faculdade de Odontologia de Bauru, Universidade de São Paulo.

19. CHAIN, J.; JONES, M. K.; TARNAWSKI, A. S. Serum response factor is a critical requirement for VEGF signaling in endothelial cells and VEGFinduced angiogenesis. The Faseb Journal, p.1-19, June 2004. 
20. CHARNOCK-JONES, D. S.; HE, Y.; SMITH, S. K. Angiogenesis and vascular endothelial growth factor (VEGF) in reproduction. In: FAN, T. D.; KOHN, E. C. The new angiotherapy. Totowa: Humana Press, 2002. Cap.8, p. 115-124.

21. CLAUS, I. et al. Histologic analysis of pulpal revascularization of autotransplanted immature teeth after removal of the original pulp tissue. $\mathbf{J}$ Orthod Dentofacial Orthop, Saint Louis, v.125, n. 1, p. 93-99, Jan. 2004.

22. COLBATZKY, F.; HERMANNS, W. Immunohistochemical demonstration of various antigens in tissues embedded in plastic. Histochem $\mathbf{J}$, London, v. 19, p. $589-593,1987$.

23. CVEK, M. et al. Effect of topical application of doxycycline on pulp revascularization and periodontal healing in reimplanted monkey incisors. Endod Dent Traumatol, Copenhagen, v. 6, n. 4, p. 170- 176, Aug. 1990.

24. CVEK, M. et al. Pulp revascularization in reimplanted immature monkey incisors - predictability and the effect of antibiotic systemic prophylaxis. Endod Dent Traumatol, Copenhagen, v. 6, n. 4, p. 157-169, Aug. 1990.

25. DERRINGER, K. A.; LINDEN, R. W. A. Angiogenic growth factors released in human dental pulp following orthodontic force. Arch Oral Biol, Oxford, v.48, n. 4, p. 285-291, Apr. 2003.

26. DERRINGER, K. A.; LINDEN, R. W. A. Vascular endothelial growth factor, fibroblast growth factor 2, platelet derived growth factor and transforming growth factor beta released in human dental pulp following orthodontic force. Arch Oral Biol, Oxford, v.49, n. 8, p. 631-641, Aug. 2004.

27. DOYLE, D. L.; DUMSHA, T. C.; SYDISKIS, R. J. Effect of soaking in Hank's balanced salt solution or milk on PDL cell viability of dry stored human teeth. Endod Dent Traumatol, Copenhagen, v. 14, n. 5, p. 221224, Oct. 1998.

28. DVORAK, H. F. Vascular Permeability Factor/ Vascular Endothelial Growth Factor: A critical cytokine in tumor angiogenesis and a potential target for diagnosis and therapy. J Clin Oncol, v. 20, n. 21, p. 4368-4380, Nov. 2002. 
29. DVORAK, H. F. et al. Vascular permeability factor/ vascular endothelial growth factor, microvascular hypermeability, and angiogenesis. Am J Pathol, Philadelphia, v. 146, n. 5, p. 1029-1035, May 1995.

30. EBELESEDER, K. A. et al. A study of replanted permanent teeth in different age groups. Endod Dent Traumatol, Copenhagen, v. 14, n. 6, p. 274-278, Dec. 1998.

31. ELCIN, Y. M.; DIXIT, V.; GITNICK, G. Extensive in vivo angiogenesis following controlled release of human vascular endothelial cell growth factor: implications for tissue engineering and wound healing. Artif Organs, v. 25, n. 7, p. 558-565, July 2001.

32. FATOR de crescimento vascular endotelial(VEGF). Disponível em: http:// www.Anti-VEGF.com.br/publico/ciencia 1htm. Acesso em: 04 de Jun. 2006.

33. FERRARA, N. Heterozygous embryonic lethality induced by targeted inactivation of the VEGF gene. Nature, London, v. 380, n. 6573, p. 439442, Apr. 1996.

34. FERRARA, N. Vascular endothelial growth factor. Eur J Cancer, Oxford, v. 32A, n. 14, p 2413- 2422, Dec. 1996.

35. FERRARA, N. Molecular and biological properties of vascular endothelial growth factor. J Mol Med, v.77, n. 7, p.527-543, July 1999.

36. FERRARA, N. VEGF: an update on biological and therapeutic aspects. Curr Opin Biotechnology, London, v. 11, n.6, p.617-624. Dec. 2000.

37. FERRARA, N. Role of Vascular endothelial growth factor in regulation of physiological angiogenesis. Am J Physiol Cell Physiol, Bethesda, v. 280, n. 6, p. C 1358-1366, June 2001.

38. FERRARA, N. VEGF and Quest for Tumor Angiogenesis Factors. Nat Rev Cancer, London, v. 2, n. 10, p. 795-803, Oct. 2002.

39. FERRARA, N. Vascular endothelial growth factor: Basic Science and Clinical Progress. Endocrine Reviews, v. 25, n. 4, p. 581-611, Aug. 2004. 
40. FERRARA, N; ALITALO, K. Clinical applications of angiogenic growth factors and their inhibitors. Nat Med, New York, v. 5, n. 12, p. 1359-1364, Dec. 1999

41. FERRARA, N.; HENZEL, W. J. Pituitary follicular cells secrete a novel heparin-binding growth factor specific for Vascular endothelial cells. Biochem Biophys Res Commun, New York, v. 161, n. 2, p. 851-858, June. 1989.

42. FERRARA, N; GERBER, H. P.; LeCOUTER, J. The biology of VEGF and its receptors. Nat Med, New York, v. 9, n. 6, p. 669-676, June 2003.

43. FOLKMAN, J. Angiogenesis in cancer, vascular, rheumatoid and other disease. Nat Med, New York, v. 1, n. 1, p. 27- 31, Jan. 1995.

44. FOLKMAN, J.; KLAGSBRUN, M. Angiogenic factors. Science, Washington, v. 235, n. 4787, p. 442-447, Jan. 1987.

45. FOLKMAN, J.; SHING, Y. Angiogenesis. J Biol Chem, Baltimore, v. 267, n. 16, p. 10931-10934, June 1992.

46. FONG, G. H. et al. Role of the Flt-1 receptor tyrosine kinase in regulating the assembly of vascular endothelium. Nature, London, v. 376, n. 6535, p. 66-70, July 1995.

47. GOODIS, H.; SAEKI, K. Identification of bradykinin, substance $P$, and neurokinin $A$ in human dental pulp. J Endod, Chicago, v. 23, n. 4, Apr. 1997.

48. GOUNIS, M. J. et al. Angiogenesis is confined to the transient period of VEGF expression that follows adenoviral gene delivery to ischemic muscle. Gen Ther, London, v. 12, n.9, p. 1-10, Mar. 2005.

49. HANKS, CT. et al. Cloned $3 T 6$ cell line from CD-1 mouse fetal molar dental papillae. Connect Tissue Res, New York, v.37, n. 3-4, p. 233-249, 1998.

50. HEYERAAS, K. J.; BERGGREEN, E. Intersticial fluid pressure in normal and inflamed pulp. Crit Rev Oral Biol. Med, Boca Raton, v. 10, n. 3, p. 328-336, 1999. 
51. HEYWOOD, B.R; APPLETON, J. The ultrastructure of the rat incisor odontoblast in organ culture. Arch Oral Biol, Oxford, v. 29, n. 4, p. 327329, Jan./June 1984.

52. HICKLIN, D.; ELLIS, L. M. Role of the vascular endothelial growth factor pathway in tumor growth and angiogenesis. J Clin Oncol, New York, v. 23, n. 5, p. 1011- 1027, Feb. 2005.

53. HOEBEN, A. et al. Vascular Endothelial Growth Factor and Angiogenesis. Pharmacol Rev, Baltimore, v.56, n.4, p.549-580, Dec. 2004.

54. HOUCK, K. A. et al. Dual regulation of vascular endothelial growth factor bioavailability by genetic and proteolytic mechanisms. J Biol Chem, Baltimore, v. 267, n. 36, p. 26031-26037, Dec. 1992.

55. IN SITU CELL DEATH DETECTION KIT, AP. Tunel Assay. Disponível em: <http://www.roche-applied-science.com/pack-insert/11684809910a.pdf > Acesso em Set. de 2005.

56. ISRAELS, L. G.; ISRAELS, E. D. Apoptosis. Stem Cells, Basel, v.17, n. 5, p. 306-313, Sept. 1999.

57. JACOBY, B. H. et al. An Ultrastructural and Immunohistochemical study of human dental pulp: identification of Weil-Palade bodies and von Willebrand factor in pulp endothelial cells. J Endod, Chicago, v. 17, n. 4, p. 150-155, Apr. 1991.

58. JAFFE, E. A.; HOYER, L. W.; NACHMAN, R. L. Synthesis of von Willebrand factor by cultured human endothelial cells. Proc Nat Acad Sci, Washington, 71, n. 5, p. 1906- 1909, May 1974.

59. JAIN, R. et al. Quantitative angiogenesis assays: progress and problems. Nature Med, London, v. 3, n. 11, p. 1203-1208, Nov. 1997.

60. JOHNSON, W. T. et al. Replantation of avulsed teeth with immature root development. Oral Surg Oral Med Oral Pathol, Saint Louis, v. 60, n. 4, p. 420-427, Oct. 1985.

61. JORDÃO, B. Q.; ANDRADE, C. G. T.J. Ciclo celular e meiose. In: JUNQUEIRA, L. C.; CARNEIRO, J. Biologia celular e molecular. 7. ed. Rio de Janeiro: Guanabara Koogan, 2000. Cap. 9, p. 171-197. 
62. JUNQUEIRA, L. C.; CARNEIRO, J. Comunicações celulares por meio de sinais químicos. In: Biologia celular e molecular. 7. ed. Rio de Janeiro: Guanabara Koogan, 2000. Cap. 6, p. 103-115.

63. KATSUBE, K. et al. Vascular endothelial growth factor (VEGF) gene transfer enhances surgical revascularization of necrotic bone. J Orthop Res, Wiley, v. 23, n. 2, p. 469-474, Mar. 2005.

64. KECK, P. M. et al. Vascular permeability factor, an endothelial cell mitogen related to PDGF. Science, Washington, v. 246, n. 4935, p.1309-1312, Dec. 1989.

65. KERBEL, R. S. Tumor angiogenesis: past, present and near future. Carcinogenesis, New York, v. 21, n. 3, p. 505-515, 2000.

66. KERR, J. F; WYLLIE, A. H.; CURRIE, A. R. Apoptosis: a basic biological phenomen with wide-ranging implications in tissue kinetics. $\mathrm{Br} \mathbf{J}$ Cancer, London, v.26, n. 4, p.239-257, Aug. 1972.

67. KIM, H. J. et al. Vascular endothelial growth factor- induced angiogenic gene therapy in patients with peripheral artery disease. Exp Mol Med, Seoul, v. 36, n. 4, p. 336-344, Aug. 2004.

68. KLAGSBRUN, M.; TAKASHIMA, S.; MAMLUK, R. The role of neuropilin in vascular and tumor biology. Adv Exp Med Biol, New York, v.515, p. 3348, 2002.

69. KLEIMAN, N. S. et al. Evolving revascularization approaches for myocardial ischemia. Amer J Cardiol, v. 92, n. 9, p. 9-17, Nov. 2003. Suplement 2.

70. KORANSKY, M. L.; ROBBINS, R. C.; BLAU, H. M. VEGF gene delivery for treatment of ischemic cardiovascular disease. Trends Cardiovasc Med, New York, v. 12, n. 3, p. 108-114, Apr. 2002.

71. LAUREYS, W. et al. Revascularization after cryopreservation and autotransplantation of immature and mature apicoectomized teeth. Am J Orthod Dentofacial Orthop, Saint Louis, v. 119, n. 4, p. 346-352, Apr. 2001. 
72. LEUNG, D. W. et al. Vascular endothelial growth factor is a secreted angiogenic mitogen. Science, Washington, v. 246, n. 4935, p.1306-1309, Dec. 1989.

73. LEVIN, L. et al. Effect of topical alendronate on root resorption of dried replanted dog teeth. Dent Traumatol, Copenhagen, v. 17, n. 3, p. 120126, June 2001.

74. LOVE, R. M.; JENKINSON, H. F. Invasion of dentinal tubules by oral bacteria. Crit Rev Oral Biol Med, Boca Raton, v.13, n. 2, p. 171-183, 2002.

75. LUSTOSA-PEREIRA, A. et al. Evaluation of the topical effect of alendronate on the root surface of extracted and replanted teeth. Microscope analysis on rat's teeth. Dent Traumatol, Copenhagen, v. 22, n. 1, p. 30-35, Feb. 2006.

76. MAGLOIRE, A.; JOFFRE, A.; BLEICHER, F. An vitro model of human dental pulp repair. J Dent Res, Chicago, v. 75, n. 12, p.1971-1978. Dec. 1996.

77. MANTELLINI, M. G. et al. Adhesive resin induces apoptosis and cell-cycle arrest of pulp cells. J Dent Res, Chicago, v. 82, n. 8, p. 592- 596, Aug. 2003.

78. MATSUSHITA, K. et al. Lipopolyccharide enhances the production of vascular endothelial growth factor by human pulp cells in culture. Infect Immun, Bethesda, v. 67, n. 4, p. 1633-1639, Apr. 1999.

79. MATSUSHITA, K. et al. The role of vascular endothelial growth factor in human dental pulp cells: induction of chemotaxis, proloferation, and differentiation and activation of AP-1- dependent signaling pathway. J Dent Res, Chicago, v. 79, n. 8, p.1596-1603, Aug. 2000.

80. MATTUELLA, L. G. Expressão do VEGFR-2 em polpas de dentes decíduos e permanentes jovens humanos. 54p. Dissertação (Mestrado) - Faculdade de Odontolologia de Porto Alegre, Universidade Federal do Rio Grande do Sul. 
81. MCLACHLAN, J. L.; SMITH, A. J.; COOPER, P. R. Piezo-power microdissection of mature human dental tissue. Arch Oral Biol, Oxford, v. 48, n. 10, p. 731-736, Oct. 2003.

82. MILLER, R. T.; SWANSON, P. E.; WICK, M. R. Fixation and epitope retrievel in diagnostic immunohistochemistry: a concise review with practical considerations. Appl Immunohistochem Mol Morphol, v. 8, n. 3, p. 228-235, Sept. 2000.

83. MIYAUCHI, M. et al. Immunohistochemical demonstration of Prostaglandins $E_{2}, F_{2 \alpha}$, and 6- Keto- prostaglandin $F_{1 \alpha}$ in Rat dental pulp with experimentally induced inflammation. J Endod, Chicago, v. 22, n. 11, p. 600-602, Nov. 1995.

84. MOGHADDAME-JAFARI. et al. Effect of Pro-Root MTA on Pulp Cell Apoptosis and Proliferation In Vitro. J Endod, Chicago, v. 31, n. 5, p. 387391, May 2005.

85. MORI, G.G. Estudo microscópico e morfométrico do efeito de substâncias anti-reabsortivas usadas como medicação intracanal em dentes de ratos avulsionados e reimplantados tardiamente. Bauru, 2005. 109p. Tese (Doutorado) - Faculdade de Odontologia de Bauru, Universidade de São Paulo.

86. MOULD, A. W. et al. Transgenic overexpression of vascular endothelial growth factor-B isoforms by endothelial cells potentiates postnatal vessel growth in vivo and in vitro. Circ Res, Baltimore, v. 97, n. 7, p. 1-11, Sept. 2005.

87. MURRAY, P. E.; SMITH, A. J. Saving pulps: a biological basis. An overview. Prim Dent Care, London, v. 9, n. 1, p. 21- 26, Jan. 2002.

88. MURRAY, P. E. et al. Tooth slice organ culture for cytotoxicity assessment of dental materials. Biomaterials, Guildford, v. 21, n. 16, p. 1711-1721, Aug. 2000.

89. NEUFELD, G. et al. Vascular endothelial growth factor (VEGF) and its receptors. The FASEB Journal, v. 13, n. 1, p.9-22, Jan. 1999. 
90. NISSEN, N. N. et al. Vascular endothelial growth factor mediates angiogenic activity during the proliferative phase of wound healing. Am $\mathbf{J}$ Pathol, Philadelphia, v. 152, n. 6, p. 1445-1452, June 1998.

91. NÖR, J. E. Genética e biologia molecular na promoção de saúde. In: Toledo, O. A. Odontopediatria: fundamentos para a prática clínica. 3. ed. São Paulo: Editorial Premier, 2005. Cap.7, p. 153-162.

92. NÖR, J. E.; POLVERINI, P. Role of endothelial cell survival and death signals in angiogenesis. Angiogenesis, London, v. 3, n. 2, p. 101-116, 1999.

93. NÖR, J. E. et al. Vascular endothelial growth factor (VEGF) - mediated angiogenesis is associated with enhanced endothelial cell survival and induction of Bcl-2 expression. Am J Pathol, Philadelphia, v. 154, n. 2, p. 375-384, Feb. 1999.

94. NÖR, J. E. et al. Engineering and characterization of functional human microvessels in immunodeficient mice. Lab. Invest, New York, v. 81, n. 4, p. 453-463, Apr. 2001.

95. NÖR, J. E. et al. Up-regulation of $\mathrm{Bcl}-2$ in microvascular endothelial cells enhances intratumoral angiogenesis and acelerates tumor growth. Cancer Res, Chicago, v. 61, n. 5, p. 2183-2188, Mar. 2001.

96. NÖR, J. E. et al. Ablation of microvessels in vivo upon dimerization of icaspase 9. Gene Ther, Hound Mills, v. 9, n .7, p. 444-451, Apr. 2002.

97. ONE step RT-PCR. Disponível em:<http://www.invitrogen.com/content. cfm?pageid=9964. $>$ Acesso em 4 de Jun. 2006.

98. PARK, J. E.; KELLER, G. A.; FERRARA, N. The vascular endothelial growth factor (VEGF) isoforms: differential deposition into the subepithelial extracellular matrix and bioactivity of extracellular matrix- bound VEGF. Mol Biol Cell, Bethesda, v. 4, n. 12, p. 1317- 1326, Dec. 1993.

99. PARK, J. E. et al. Placenta growth factor. Potentiation of vascular endothelial growth factor activity, in vitro and in vivo, and high affinity bind Flt-1 but not Flk-1/ KDR. J Biol Chem, Baltimore, v. 269, n. 41, p. 2564625654, Oct. 1994. 
100. PARRISH, A.; GANDOLFI, J.; BRENDEL, K. Precision-cut tissue slices: applications in pharmacology and toxicology. Life Sci, Oxford, v. 57, n. 21, p. $1887-1901,1995$.

101. PETTIETTE, M. et al. Periodontal healing of extracted dog's teeth air-dried for extended periods and soaked in various media. Endod Dent Traumatol, Copenhagen, v. 13, n.3, p.113-118, June 1997.

102. POLVERINI, P. J. The pathophysiology of angiogenesis. Crit Rev Oral Biol Med, Boca Raton, v.6, n. 3, p. 230-247, 1995.

103. POLVERINI, P. J. Angiogenesis in health and disease: insights into mechanisms and therapeutic opportunities. J Dent Educ, v. 66, n. 8, p. 962- 975, Aug. 2002.

104. POLVERINI, P. J. et al. Growth of human blood in sever combined immunodeficient mice: a new in vivo model system of angiogenesis. Methods Mol Med, v. 78, p. 161-177, 2003.

105. PONTUAL, M. A. B.; MAGINI, R. S. Plasma rico em plaquetas (PRP) e fatores de crescimento. Ed. Santos: São Paulo, 2004. 308p.

106. RIBATTI, D. The crucial role of vascular permeability factor / vascular endothelial growth factor in angiogenesis: a historical review. $\mathbf{B r} \mathbf{J}$ Haematol, Oxford, v. 128, n. 3, p. 303- 309, Feb. 2004.

107. RITTER, A. L. S. et al. Pulp revascularization of replanted immature dog teeth after treatment with minocycline and doxycycline assed by laser Doppler flowmetry, radiography, and histology. Dent Traumatol, Copenhagen, v.20, n. 2, p.75-84, Apr. 2004.

108. ROBERTS-CLARK, D. J.; SMITH, A. J. Angiogenic growth factors in human dentine matrix. Arch Oral Biol, Oxford, v. 45, n.11, p.1013-1016, Nov. 2000.

109. ROOD, H. D.; BOISSONADE, F. M. Vascular Status in Human Primary and permanent teeth in Health and Disease. Eur J Oral Sci, Copenhagen, v. 113, n. 2, p. 128-134, Apr. 2005. 
110. ROSENSTEIN, J. M. et al. Patterns of brain angiogenesis after vascular endothelial growth factor administration in vitro and in vivo. Proc Natl Acad Sci, v. 95, n. 12, p. 7086- 7091, June 1998.

111. RUGGERI, Z. M.; ZIMMERMAN, T. S. von Willebrand factor and von Willebrand disease. Blood, v. 70, n. 4, p. 895- 904, Oct. 1987.

112. SAE-LIM, V.; METZGER, Z.; TROPE, M. Local dexamethasone improves periodontal healing of replanted dog's teeth. Endod Dent Traumatol, Copenhagen, v.14, n. 5, p. 232- 236, Oct. 1998.

113. SAKAI, V. T. Biologia molecular: princípios e aplicações das técnicas de PCR e RT-PCR em Odontologia. Bauru, 2000. 55p. Monografia Faculdade de Odontologia de Bauru, Universidade de São Paulo.

114. SATCHELL, P. G.; GUTMANN, J. L.; WITHERSPOON, D. E. Apoptosis: an introduction for the endodontist. Int Endod Journal, v. 36, n. 4, p. 237245, Apr. 2003.

115. SCHJOTT, M.; ANDREASEN, M. Emdogain does not prevent progressive root resorption after replantation of avulsed teeth: a clinical study. Dent Traumatol, Copenhagen, v.21, n. 1, p. 46-50, Feb. 2005.

116. SCHRÖDER, U. Effects of calcium hydroxide-containing pulp- capping agents on pulp cell migration, proliferation, and differentiation. J Dent Res, Chicago, v. 64, p. 541-548, Apr. 1985.

117. SENGER, D. R. et al. Tumor cells secrete a vascular permeability factor that promotes accumulation os ascites fluid. Science, Washington, v. 219, n. 4587, p. 983-985, Feb. 1983.

118. SENGER, D. R. et al. Purification and $\mathrm{NH}_{2}$ - terminal amino acid sequence of guinea pig-tumor-secreted vascular permeability factor. Cancer Res, v.50, n. 6, p. 1774-1778, Mar. 1990.

119. SHALABAY, F. et al. Failure of blood-island formation and vasculogenesis in Flk-1- deficient mice. Nature, London, v. 376 , n. 6535, p. 62-66, July 1995. 
120. SHWEIKI, D. et al. Vascular endothelial growth factor induced by hypoxia may mediate hypoxia-initiated angiogenesis. Nature, London, v. 359, n. 6396, p. 843- 845, Oct. 1992.

121. SIERS, M. L.; WILLEMSEM, W. L.; GULABILAVA, K. Monitoring pulp vitality after transplantation of teeth with mature roots: a case report. Int Endod J, v. 35, n. 3, p.289-294, Mar. 2002.

122. SIGALAS, E. et al. Survival of human periodontal ligament cells in media proposed for transport of avulsed teeth. Dent Traumatol, Copenhagen, v. 20, n. 1, p. 21-8, Feb. 2004.

123. SIMONS, M.; WARE, J. A. Therapeutic angiogenesis in cardiovascular disease. Nature Reviews, v. 2, p.1- 9, Nov. 2003.

124. SKOGLUND, A.; TRONSTAD, L. Pulpal changes in replanted and autotransplanted immature teeth dogs. J Endod, Chicago, v. 7, n. 7, p. 309-315, July 1981.

125. SLOAN, A. J. et al. An in vitro approach for the study of dentinogenesis by organ culture of the dentine-pulp complex from rat incisor teeth. Arch Oral Biol, Oxford, v. 43, n. 6, p. 421-430, June 1998.

126. SMITH, A. J. et al. Odontoblast stimulation in ferrets by dentine matrix components. Arch Oral Biol, Oxford, v. 39, n. 1, p.13-22, Jan. 1994.

127. SODEN, R. I. Intracellular signaling in LTA- induced VEGF expression of dental pulp cells. Ann Arbor, 2005. 66p. Dissertation (Master) School of Dentistry, University of Michigan.

128. SOKER, S. et al. Neuropilin- 1 is expressed by endothelial and tumor cells as an isoform- specific receptor for vascular endothelial growth factor. Cell, v. 92, n .6, p. 735-745, Mar. 1998.

129. SONG, W. et al. Antiangiogenic gene therapy: disruption of neovascular networks mediated by inducible caspase-9 delivered with a transcriptionally targeted adenoviral vector. Gene Ther, v. 12, n. 4, p. 110, Feb. 2004. 
130. STASHENKO, P.; TELES, R. Periapical Inflammatory Responses and Their Modulation. Crit Rev Oral Biol Med, Boca Raton, v. 9, n. 4, p. 498521, Nov. 1998.

131. STATON, C. A. et al. Current methods for assaying angiogenesis in vitro and in vivo. Int J Exp Path, v. 85, n. 5, p. 233-248,Oct. 2004.

132. TAMMELA, T. et al. The biology of vascular endothelial growth factors. Cardiovasc Res, London, v. 65, n. 3, p. 550- 563, Feb. 2005.

133. TELLES, P. D. S. et al. Lipoteichoic acid up-regulates VEGF expression in macrophages and pulp cells. J Dent Res, Chicago, v. 82, n. 6, p. 466470, June 2003.

134. TISCHER, E. The human gene for vascular endothelial growth factor. $\mathbf{J}$ Biol Chem, Baltimore, v. 266, n. 18, p. 11947-11954, June 1991.

135. TOMANEK, R. J.; SCHATTEMAN, G. C. Angiogenesis: new insights and therapeutic potential. Anat. Rec, New York, v. 261, n. 3, p.126-135, June 2000.

136. TROPE, M. Clinical management of the avulsed tooth: present strategies and future directions. Dental Traumatol, Copenhagen, v. 18, n. 1, p.1-11, Feb. 2002.

137. TZIAFAS, D.; KOLOKURIS, I. Inductive influences of demineralized dentin and bone matrix on pulp cells: an approach of secondary dentinogenesis. J Dent Res, Chicago, v. 69, n. 1, p.75-81, Jan. 1990.

138. TZIAFAS, D.; ALVANOU, A.; KAIDOGLOU, K. Dentinogenic activity of allogenic plasma fibronectin on dog dental pulp. J Dent Res, Chicago, v. 71, n. 5, p.1189-1195, May 1992.

139. TZIAFAS, D. et al. Short- term dentinogenic response of dog dental pulp tissue after its induction by demineralized or native dentine, or predentine. Arch Oral Biol, Oxford, v.37, n. 2, p.119-128, Jan. / June 1992.

140. VICENTI, V. et al. Assignment of the vascular endothelial growth factor gene to human chromosome 6p21.3. Circulation, Texas, v. 93, n. 8, p. 1493-1495, Apr. 1996. 
141. WALTENBERGER, J.; HOMBACH, V. Therapeutic angiogenesis for the heart. In: . FAN, T.D.; KOHN, E. C. The new angiotherapy. Totowa: Humana Press, 2002. Cap.16, p. 279- 289.

142. WALTENBERGER, J. et al. Different signal transduction properties of KDR and Flt-1, two receptors for vascular endothelial growth factor. J Biol Chem, Baltimore, v. 269, n. 43, p. 26988-26995, Oct. 1994.

143. YANCOPOULOS, G. D. et al. Vascular-specific growth factors and blood vessel formation. Nature, London, v. 407, n. 6801, p. 242-248, Sept. 2000.

144. YANPISET, K.; TROPE, M. Pulp revascularization of replanted immature dog teeth after different treatment methods. Endod Dent Traumatol, Copenhagen, v. 16, n. 5, p. 211-217, Oct. 2000. 


\section{ABSTRACT}





\section{ABSTRACT VEGF EFFECT ON PULP ANGIOGENESIS AND APOPTOSIS}

The Vascular endothelial growth factor (VEGF) plays an important role in angiogenesis by inducing endothelial cell proliferation, migration, and survival. To promote new vessel formation and improve collateral circulation, VEGF has been used to treat ischemic heart areas in cardiovascular disease. Maintenance of pulp vitality with VEGF may improve the outcomes of avulsed teeth, preventing premature tooth loss. The purpose of this study was to develop a model system to study the process of dental pulp revascularization, and assess the effect of VEGF-165 in the human pulp angiogenesis and apoptosis. Human tooth slices were maintained in vitro for 7 days +/- VEGF (50ng/mL). Immunohistochemistry staining for Von Willebrand's factor (Factor VIII) was used to quantify the number of vessels in pulp tissues. There was a significantly higher number of blood vessels in the VEGF group (67.8 Mean) compared to the control group (46.2 Mean, $p<0.05$ ). Tunel Assay was used to determine the number of apoptotic cells in +/- VEGF groups. RTPCR analyses of VEGFR-2 transcripts were used on human dermal microvascular endothelial cells (HDMECs), undifferentiated pulp cells (OD-21), mouse odontoblast-like cells (MDPC-23), and macrophages. VEGFR-2 expression was detected in HDMECs but not in the other 3 cell lines. Four tooth slices per mouse were subcutaneously implanted in the dorsal region for 7 days. Pulp vitality was determined by histological and immunohistochemical analysis. Also, Tunel Assay was used to determine the number of apoptotic cells. SCID mouse model of pulp angiogenesis demonstrated to be a good model system to study revascularization of human dental pulps. Taking into account the findings of this study, it is suggested that VEGF could have a positive effect in the revascularization of avulsed teeth. It is hoped that this pulp angiogenesis model be useful to answer a number of new experimental questions in the area of Endodontics.

KEY WORDS: Angiogenesis, Vascular endothelial growth factor (VEGF), VEGFR-2, Dental pulp and avulsion 

APÊNDICE 



\section{APÊNDICE}

Transcrição reversa - Reação em cadeia de Polimerase (RT-PCR) (Reverse Transcriptase Polymerase Chain Reaction)

\section{Extração de RNA}

RNA total das células (OD-21,MDPC-23, macrófagos e HDMECs) foi extraído de acordo com as orientações do fabricante do RNAeasy Mini kit, Qiagen, Valência CA, USA. Todo o processo detalhado pode ser encontrado no endereço:

http://

www.qiagen.com/literature/handbooks/rna/rnamini/1016272HBRNY Iso a nim cell.pdf. As amostras de RNA total foram mantidas a $-80^{\circ} \mathrm{C}$ até o momento de sua utilização.Um dia antes da realização da extração de RNA, foram preparadas as células em placas (dishes) de $10 \mathrm{~mm}$, a fim de se obter um número suficiente de células para extração. As mesmas permaneceram na incubadora por $24 \mathrm{~h}$.

Extração de RNA reagentes e equipamentos

1. RNAeasy Mini kit (Qiagen, Valencia CA, USA)

2. 14.3 Mß- mercaptoethanol ( $\beta-\mathrm{ME})$

3. Rnase-free pontas e pipetas (estéril)

4. Microcentrífuga ( com motor para tubos de $2 \mathrm{~mL}$ )

5. Seringas plásticas estéril agulha 20 com $0.9 \mathrm{~mm}$ diametro) - para homogeneização

6. Etanol $(70 \%)$

Protocolo para extração de RNA

\section{Coleta das amostras}

$\stackrel{4}{4}$ Aspirar o meio de cultura da placa preparado previamente à extração;

$\stackrel{M}{\rightarrow}$ Lavar com tripsina $5 \mathrm{ml}$ ((corresponde a um frasco T75) e aspirar;

$\stackrel{\leftrightarrow}{\rightarrow}$ Adicionar $2.5 \mathrm{ml}$ de tripsina e deixar na placa por 3-5 minutos na incubadora; 
$\Leftrightarrow$ Adicionar $7.5 \mathrm{ml}$ de DMEM para neutralizar a tripsina, e colocar no tubo de ensaio de $15 \mathrm{ml}$ para centrifugação $\left(800 \mathrm{rpm}-5 \mathrm{~min}-4^{\circ} \mathrm{C}\right)$ para formação do pellet;

$\Leftrightarrow$ Ressuspender as células em PBS 1X (Gibco, Grand Island, NY,USA), centrifugar (800 rpm $-5 \mathrm{~min}-4^{\circ} \mathrm{C}$ ) para formação de um novo pellet. $\mathrm{O}$ supernadante deve ser aspirado completamente;

$\Leftrightarrow$ Manter o tubo de $15 \mathrm{ml}$ com o pellet em gelo.

\section{Ruptura das células com tampão RTL (buffer RTL)}

$\Leftrightarrow$ Primeiramente preparou-se a solução de $\beta-M E /$ Buffer RTL que foi adicionada ao pellet. ( $\beta$-ME é uma solução tóxica que deve ser preparada no interior de uma capela de fluxo laminar). Para preparar a solução, adicione 10ul $\beta$-ME por $1 \mathrm{ml}$ de buffer RTL;

$\Leftrightarrow$ Adicionar $600 \mu \mathrm{l}$ RTL para cada pellet, misture o pellet + RTL;

$\Leftrightarrow$ Colocar a amostra em um eppendorf;

$\Leftrightarrow$ Vortex 3 segundos.

\section{Homogeneização da amostra}

O lisado foi passado 5 vezes através de uma agulha 20 com $0.9 \mathrm{~mm}$ de diâmetro acoplada a uma seringa plástica estéril.

4. Seissentos microlitros $(600 \mu \mathrm{l})$ de etanol $70 \%$ foi adicionado na amostra homogeneizada, misturando-se esta solução através da pipetagem, sem centrifugar.

5. Uma coluna Rneasy que retém o RNA (Rneasy mini column), foi colocada em um tubo de microcentrífuga $(2 \mathrm{~mL})$ e $700 \mu \mathrm{l}$ da mistura foi adicionado. $\mathrm{O}$ tubo foi fechado e centrifugado por 15 segundos/ $\geq 10,000 \mathrm{rpm}$. O filtrado foi descartado. O remanescente da mistura foi adicionado em outro tubo de microcentrífuga e centrifugado como já citado. $O$ filtrado foi descartado. 


\section{DNase STEP:}

\section{Tratamento do RNA total com Dnase}

Para que fosse evitada a possibilidade de contaminação do RNA total, extraído de diferentes células por DNA genômico, procedeu-se o tratamento de todas as amostras com o conjunto livre de DNAse e RNAse (RNAse-Free Dnase Set - Cat. $n^{\circ}$. 79254) durante 15 minutos em temperatura ambiente. Este procedimento foi realizado seguindo-se as orientações do fabricante Rneasy mini kit. Todo o processo detalhado pode ser encontrado no endereço: htpp:/www.qiagen.com/literature/handbooks/rna/rnamini/1016272 HBRNY cleanup.pdf.

D1: Trezentos e cinqüenta $(350 \mu \mathrm{l})$ de Buffer RW1 foi adicionado no interior de uma coluna Rneasy, que retém o RNA, e centrifugado por 15 segundos / $\geq$ 10,000 rpm para lavar o tubo de coleta. Descarte o filtrado

D2: Adicionar $10 \mu$ l DNASE I solução de estoque em $70 \mu$ l do conjunto livre de DNAse e RNAse (RNASE-free DNASE set)

D3: Pipetou-se esta mistura DNASE I (80 $\mu$ l) diretamente sobre a RNEASY sílica- gel membrana, deixando-a sobre a bancada por 15 minutos.

D4: Trezentos e cinqüenta $(350 \mu \mathrm{l})$ de Buffer RW1 foi adicionado no interior da coluna Rneasy, que retém o RNA, e centrifugado por 15 segundos/ $\geq$ 10,000rpm. Descarte o filtrado.

7. Transferiu-se a coluna Rneasy para um novo tubo de microcentrífuga ( $2 \mathrm{ml})$ e $500 \mu \mathrm{l}$ de Buffer RPE foi adicionado. O tubo foi fechado e centrifugado por 15 segundos/ $\geq 10,000 \mathrm{rpm}$ para lavar a coluna Rneasy . O filtrado foi descartado.

8. Foi adicionado mais $500 \mu \mathrm{l}$ de Buffer RPE na coluna Rneasy. O tubo foi fechado e centrifugado por 2 minutos/ $\geq 10,000 \mathrm{rpm}$ para secar a membrana de sílica-gel. 
8.a. Colocou-se a coluna Rneasy em um tubo novo de $2 \mathrm{ml}$, descartou-se o antigo com o filtrado. Centrifugou-se em uma microcentrífuga na velocidade máxima por 1 minuto.

9. A coluna Rneasy foi transferida para um eppendorf novo de $1.5 \mathrm{ml}$ e foi pipetado 30-50 $\mu \mathrm{l}$ de água livre de Rnase (Rnase-free water) diretamente sobre a membrana (Rneasy silica -gel). O tubo foi fechado e centrifugado por $1 \mathrm{~min} /$ $\geq 10,000 \mathrm{rpm}$.

10. Vinte microlitros $(20 \mu \mathrm{l})$ de água livre de Rnase (Rnase-free water) foi adicionado na mesma coluna Rneasy / eppendorf de $1.5 \mathrm{~mL}$ e centrifugado por mais $1 \mathrm{~min} / \geq 10,000 \mathrm{rpm}$.

Com o RNA obtido, passou-se à realização da quantificação e determinação da qualidade do RNA total.

\section{Quantificação e qualidade do RNA total}

A concentração de RNA total nas amostras foi determinada por diluição do RNA (1:99 em Rnase free water)= 100x de diluição $(1 \mu \mathrm{l}$ RNA + $99 \mu \mathrm{l}$ RNase free water) e leitura em cubetas de quartzo em espectrofotômetro no comprimento de onda de $260 \mathrm{~nm}$. A fórmula para calcular a concentração de RNA total foi a seguinte: $[R N A]=A_{260} \times 40 \times 100$ (fator de diluição), sendo o resultado expresso em $\mu \mathrm{g} / \mathrm{mL}$. A qualidade do RNA, de acordo com os dados obtidos com o espectrofotômetro, foi observada através da relação $A_{260} / A_{280}$, a qual foi considerada aceitável se estivesse maior que 1,5 e menor que 2,2 ), pois valores neste intervalo indicam ausência de DNA na amostra.

O restante do RNA foi acondicionado por dois dias na temperatura de $-20^{\circ} \mathrm{C}$ para posteriormente ser armazenado na temperatura de $-80^{\circ} \mathrm{C}$.

\section{Projeto- piloto}

Foi desenvolvido, durante o período de 3 meses, com o intuito de estabelecer os protocolos para a metodologia proposta. Após a 
resolução de inúmeros problemas surgidos, chegou-se ao resultado almejado, por meio do qual verificou-se que o tecido pulpar contido nas fatias dentárias mantidas em cultura por 7 dias manteve-se viável apresentando aspectos de normalidade celular e morfológicas (figura A). Baseado nos resultados obtidos, deu-se início ao desenvolvimento da pesquisa proposta.
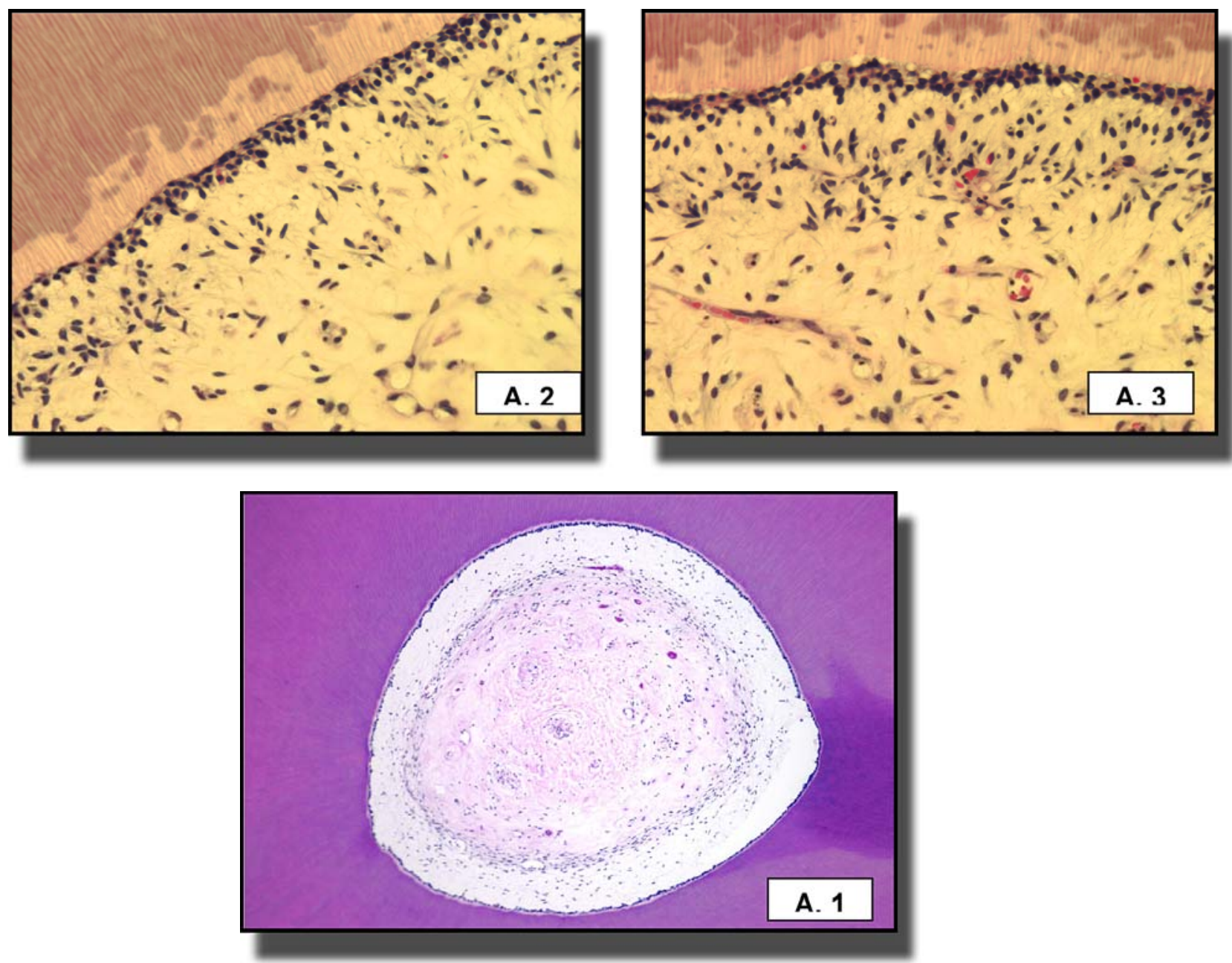

Figura A - Tecido pulpar e camada odontoblástica com aspectos de normalidade, apresentando significante número de células e vasos sangüíneos. (HE 10x (A.1); e 400X (A.2; A.3) 